\title{
VEHICLE-SCALE INVESTIGATION OF A FLUORINE JET-PUMP LIQUID HYDROGEN TANK PRESSURIZATION SYSTEM
}

by

E. C. CADY AND D. W. KENDLE

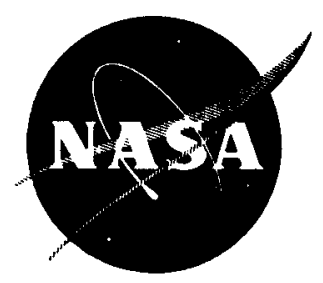

MCDONNELL DOUGLAS ASTRONAUTICS COMPANY HUNTINGTON BEACH, CALIFORNIA

PREPARED FOR

NATIONAL AERONAUTICS AND SPACE ADMINISTRATION

28 FEBRUARY 1972

CONTRACT NAS3-14381

NASA Lewis Research Center

Cleveland, Ohio

Erwin A. Edelman, Project Manager

CHEMICAL AND NUCLEAR ROCKET PROCUREMENT SECTION 


\section{PREFACE}

This report was prepared by McDonnell Douglas Astronautics Company under Contract NAS3-14381. The contract is administered by the National Aeronautics and Space Administration, Lewis Research Center, Chemical and Nuclear Rocket Procurement Section, Cleveland, Ohio. The NASA Project Manager for the contract is Mr. Erwin A. Edelman. This is the final report on the contract, and it summarizes the technical effort from 1 July 1971 to 31 January 1972. 


\section{ABSTRACT}

A comprehensive analytical and experimental program was performed to evaluate the performance of a unique fluorine-hydrogen jet-pump injector for main tank injection (MTI) pressurization of a liquid hydrogen $\left(\mathrm{LH}_{2}\right)$ tank. The injector performance during pressurization and $\mathrm{LH}_{2}$ expulsion was determined by a series of seven tests of a full-scale injector and MTI pressure control system in a $28.3 \mathrm{~m}^{3}\left(1,000 \mathrm{ft}^{3}\right)$ flight-weight $\mathrm{LH}_{2}$ tank. Although the injector did not effectively jetpump $\mathrm{LH}_{2}$ continuously, it showed improved pressurization performance compared to straight-pipe injectors tested under the same conditions in a previous program. The MTI computer code was modified to allow performance prediction for the jet-pump injector. 


\section{SUMMARY}

A comprehensive analytical and experimental program was performed to evaluate the performance of a unique two-stage supersonic jet-pump injector, developed by North American Rockwell-Rocketdyne (NAR) for main tank injection (MTI) pressurization of large-scale liquid hydrogen $\left(\mathrm{LH}_{2}\right)$ tanks. The injector first stage uses the injectant gaseous fluorine $\left(G_{2}\right)$ to pump sufficient hydrogen (design $O / F$ ratio of $800: 1)$ to heat the $G_{2}$ prior to entering the second stage. In the second stage, the heated $\mathrm{GF}_{2}$ is expanded through a supersonic nozzle to a low pressure which is used to pump $\mathrm{LH}_{2}$ from the tank into a downstream combustion zone at a design $O / F$ ratio of $1.8: 1$. The resultant hot hydrogen at $1555^{\circ} \mathrm{K}\left(2800^{\circ} \mathrm{R}\right)$ is used to pressurize the $\mathrm{LH}_{2}$ tank. The injector was tested in a $28.3-\mathrm{m}^{3}\left(1,000-\mathrm{ft}^{3}\right)$ flightweight $\mathrm{LH}_{2}$ tank used in a previous program under Contract NAS3-13306 to evaluate straight-pipe and diffuser-type MTI injectors. Seven tests were performed at varied $\mathrm{LH}_{2}$ outflow rates and with ullage volumes from $3 \mathrm{~m}^{3}\left(106 \mathrm{ft}^{3}\right)$ to $26.9 \mathrm{~m}^{3}\left(950 \mathrm{ft}^{3}\right)$. Prepressurization, constant-pressure hold, and $\mathrm{LH}_{2}$ expulsion at controlled tank pressures of $30 \times 10^{4} \mathrm{~N} / \mathrm{m}^{2}(43 \mathrm{psia})$ and $18 \times 10^{4} \mathrm{~N} / \mathrm{m}^{2}$ (26 psia) were demonstrated. The injector second stage $\mathrm{LH}_{2}$ pumping annulus was damaged by overheating caused by its inability to pump $\mathrm{LH}_{2}$ with large initial ullages and with cyclic operation. Nevertheless, the injector demonstrated improved pressurization performance (less $\mathrm{GH}_{2}$ usage and lower ullage temperature) compared to straight-pipe injectors tested previously. Analytical correlation of the data indicated that the performance gain was due to first stage $\mathrm{GF}_{2}$ heating and second stage $\mathrm{GH}_{2}$ pumping which gave greater injectant jet penetration and ullage mixing. Modifications were made to the MTI computer code to allow jet-pump injector performance prediction. 


\section{CONTENTS}

INTRODUCTION 1

PRESSURIZATION SYSTEM DESIGN

Injector Design 5

Experimental System Design $\quad 15$

Test Tank System 15

Test Facility System 16

Instrumentation System $\quad 20$

MTI System Modifications $\quad 32$

EXPERIMENTAL RESULTS

Injector Demonstration Test 43

$\begin{array}{ll}\text { Pressurization Tests } & 47\end{array}$

ANALYSIS AND COMPARISON OF INJECTORS 63

Basic Analysis 63

Comparison of Injectors $\quad 72$

Analytic Correlation with Experimental Data 83

Ullage Gas Temperature and GF 2 Usage 83

Ullage Gas Mass and Tank Enthalpy Balance 109

Analysis Modifications 111

MTI System Considerations 113

CONCLUSIONS 115

$\begin{array}{ll}\text { REFERENCES } & 117\end{array}$

APPENDIX Distribution List 119 


\section{FIGURES}

$1 \quad$ NAR Injector Configuration 6

2 NAS3-13328 Injector Flow Characteristics · 8

3 Injector Assembly (NAR Drawing AP71-180) 9

$4 \quad$ NAR Injector Retail Parts 11

$5 \quad$ Assembled NAR Injector 13

6 Enlarged NAR Injector Flow Calibration 14

$7 \quad$ NAR Injector Pumping Characteristics 15

$8 \quad$ Test Tank Installed at Alpha Test Stand $\quad 17$

9 Alpha Complex 18

10. Side View of Test Tank 19

Test Tank Instrumentation Location and
Nomenclature

12 Thermopile Assembly 22

13 Thermopile Element Detail 24

$14 \quad$ Fluxmeter Installation 26

15 Interior View of Test Tank 26

16 Test Tank Injector Installation 33

17 Pressure Regulator Drawing 38

18 Injection Assembly Installation on Test Tank 40

19 Injector Demonstration Test Apparatus $\quad 45$

20 Installation of Injector Test Apparatus 45

$21 \quad$ Injector Installation Following Firing Test 48

22 Injector Damage From Firing Test 48 
23 MTI Control System Response - 5\% Ullage

24 MTI Control System Response - 50\% Ullage

Prepressurization

25 MTI Control System Response - 50\% Ullage Outflow

26 Injector Damage from Pressurization Test

Injector $\mathrm{LH}_{2}$ Line Temperature History

Finite Difference Node System

29a Ullage Temperature Comparison, 50\% Ullage

29b Ullage Gas Temperature Comparison, 50\% Ullage

29c Ullage Gas Temperature Comparison, 50\% Ullage

Ullage Gas Temperature Comparison, 5\% Ullage

Ullage Gas Temperature Comparison, 5\% Ullage

Ullage Gas Temperature Comparison, 5\% Ullage

30d Ullage Gas Temperature Comparison, 5\% Ullage

31 Temperature Correlation for Test 3, NAS3-14381, Zero $\mathrm{H}_{2}$ Aspiration

32 Temperature Correlation for Test 3, NAS3-14381, with $\mathrm{H}_{2}$ Aspiration

33 Temperature Correlation for Test 6, NAS3-14381

34 Temperature Correlation for Test 7, NAS3-14381

35 Temperature Correlation for Test 2, NAS3-14381

36 Forced Convection Heat Transfer Velocity Correlation

37 Temperature Correlation for Test 2, NAS3-13306, Straight - Pipe

Temperature Correlation for Test 14, NAS3-13306, Straight-Pipe 
39 Temperature Correlation for Test 1, NAS3-14381 102

40 Temperature Correlation for Test 4, NAS3-14381 103

41 Temperature Coreelation for Test 5, NAS3-13306, . 104

42 Temperature Correlation for Test 5, NAS3-14381 106

43 Temperature Correlation for Test 5, NAS3-14381, $\left(\mathrm{O} / \mathrm{F}=30, \mathrm{~T}_{\mathrm{j}}=1390^{\circ} \mathrm{K}\left(2500^{\circ} \mathrm{R}\right)\right)$

44 Temperature Correlation for Test 7, NAS3-13306, Straight-Pipe 


\section{TABLES}

$1 \quad$ Instrumentation Data 28

$2 \quad$ Pressurization Test Sequence $\quad 49$

$3 \quad$ Pressurization Test Data Summary 52

$4 \quad$ Injector $\mathrm{H}_{2}$ Pumping Performance 62

$5 \quad \mathrm{GF}_{2}$ Usage Comparison 72

6 Comparison of $\mathrm{GF}_{2} \mathrm{U}$ sage and $\mathrm{LH}_{2}$ Evaporation 81

$7 \quad$ Comparison of Observed and Predicted

Cumulative $\mathrm{GF}_{2}$ Usage

8 Comparison of Observed and Predicted

Cumulative GF 2 Usage from NAS3-13306 99

9 Mass Balances, 5\% Ullage 110

10 Comparison of Observed and Predicted Ullage
Mass from NAS3-13306 


\section{SYMBOLS}

$\begin{array}{ll}\text { a } & \text { Acceleration } \\ \mathrm{C}_{\mathrm{p}} & \text { Area } \\ \mathrm{C} & \text { Specific heat at constant pressure } \\ \mathrm{d} & \text { Constant } \\ \mathrm{f} & \text { Injector on-time fraction } \\ \mathrm{f}_{\mathrm{m}} & \text { Ullage mixing fraction } \\ \mathrm{h} & \text { Heat transfer coefficient } \\ \mathrm{K} & \text { Thermal conductivity } \\ \dot{\mathrm{m}} & \text { Mass flowrate } \\ \mathrm{P} & \text { Pressure } \\ \dot{\mathrm{q}} & \text { Heat flux } \\ \mathrm{R} & \text { Universal gas constant } \\ \mathrm{t} & \text { Time } \\ \mathrm{T} & \text { Temperature } \\ \mathrm{U} & \text { Velocity } \\ \mathrm{V} & \text { Observed forced-convection velocity } \\ \mathrm{W} & \text { Molecular weight } \\ \mathrm{X} & \text { Distance on the vertical axis } \\ \Delta & \text { Increment } \\ \mathrm{P} & \text { Density } \\ \mu & \text { Viscosity }\end{array}$

\section{Subscripts}

\begin{tabular}{ll}
\hline$b$ & Buoyancy \\
$c$ & Combustion \\
C & Jet velocity core \\
fo & Forced \\
F & Flame \\
$F_{2}$ & Fluorine
\end{tabular}




$\begin{array}{ll}\mathrm{g} & \text { Gas } \\ \mathrm{H}_{2} & \text { Hydrogen } \\ \mathrm{HF} & \text { Hydrogen fluoride } \\ \text { if } & \text { interface } \\ \mathrm{in} & \text { injector exit plane } \\ \mathrm{j} & \text { Injectant jet flow } \\ \mathrm{L} & \text { Liquid } \\ \mathrm{m} & \text { Maximum } \\ \mathrm{M} & \text { Turbulent mixing } \\ \mathrm{mix} & \text { Ullage mixing } \\ \mathrm{p} & \text { Jet penetration } \\ \mathrm{r} & \text { Reaction } \\ \mathrm{u} & \text { Ullage } \\ \mathrm{o} & \text { Initial }\end{array}$




\section{INTRODUCTION}

For space vehicles using cryogenic propellants, particularly those that require multiburn operation, tank pressurization can contribute significantly to the weight, complexity, and cost of the propulsion feed system. A tank pressurization concept called the main tank injection (MTI) technique can reduce the weight and complexity of the system. In the MTI technique, a hypergolic reactant is injected into a propellant tank and the heat released is used to pressurize the tank. This technique has resulted in considerable improvement in performance and cost, especially for advanced hydrogen-fueled upper stages.

From July 1966 through April 1968, McDonnell Douglas Astronautics Company (MDAC) conducted an MTI pressurization research program under NASA Contract NAS3-7963 to determine, analytically and experimentally, the feasibility, limitations, and operating characteristics of small-scale fluorine-hydrogen MTI pressurization (Reference 1 ). After the system feasibility and characteristics had been established, MDAC conducted a comprehensive program to devise an analytical method to predict MTI performance for liquid hydrogen-fueled space vehicles of any size and to develop and demonstrate a full-scale flighttype MTI pressurization system. This program was conducted from July 1969 through June 1970 under NASA Contract NAS3-13306.

In Task I of this program, a computer code was developed from an analytical technique to predict the performance and behavior of MTI pressurization of a liquid hydrogen $\left(\mathrm{LH}_{2}\right)$ tank through ullage injection of gaseous fluorine $\left(\mathrm{GF}_{2}\right)$. This code, designated $\mathrm{H} 819$, included routines to account for injection jet penetration, ullage mixing, and tank wall and $\mathrm{LH}_{2}$ interface heat (and mass) transfer using the most 
advanced one-dimensional nodal techniques. In Task II, a largescale test apparatus, including MTI injectors, tank pressure control system, and instrumentation, was designed for installation in a 28.3- $\mathrm{m}^{3}\left(1,000-\mathrm{ft}^{3}\right)$ flight-weight Thor tank. In Task III, the MTI injection system was test-fired to assure proper durability and performance and then installed in the $28.3-\mathrm{m}^{3}\left(1,000-\mathrm{ft}^{3}\right) \mathrm{LH}_{2}$ tank. A series of 17 tests was performed at ullage volumes from 5 to 90 percent, $\mathrm{LH}_{2}$ outflow rates from 2.3 to $6.8 \mathrm{~kg} / \mathrm{sec}(5$ to $15 \mathrm{lb} / \mathrm{sec}$ ), and tank pressures of $17 \times 10^{4}$ and $30 \times 10^{4} \mathrm{~N} / \mathrm{m}^{2}(25$ and $43 \mathrm{psia})$, utilizing both straight-pipe and diffuser-type injectors. Tank prepressurization, constant pressure hold at no outflow, and constant pressure expulsion modes were demonstrated with tank pressure maintained constant to within $0.7 \times 10^{4} \mathrm{~N} / \mathrm{m}^{2}$ (1 psia). In Task IV, the data from these tests were analyzed and correlated with the H819 computer code, and empirical factors in the code were determined. The H819 code was then used to predict the performance of an MTI pressurization system designed for an advanced Centaur-type vehicle.

It was found from the MTI tests conducted under Contract NAS3-13306 and reported in Reference 2 that when tank pressurization and expulsion was performed with a nearly full tank $(\sim 5$-percent ullage), the $\mathrm{GF}_{2}$ jet penetrated the $\mathrm{LH}_{2}$ interface and evaporated sufficient $\mathrm{LH}_{2}$ to keep the ullage temperatures low. As the interface receded during outflow, the $\mathrm{LH}_{2}$ evaporation ceased and the ullage temperatures rose rapidly. The higher ullage temperatures led to greater tank wall heat transfer losses, thus to increased $\mathrm{GF}_{2}$ demand and consumption. It appeared that if controlled ullage mass addition were to occur throughout the expulsion, lower temperatures and reduced fluorine usage could be realized.

Concurrent with the NAS3-13306 work by MDAC, North American Rockwell-Rocketdyne (NAR) was conducting a program under NASA Contract NAS3-13328 to develop an MTI injector which uses the GF2 
inflow to jet-pump $\mathrm{LH}_{2}$ from the tank, vaporizes the $\mathrm{LH}_{2}$, and delivers a controlled flow of hot $\mathrm{H}_{2}$ into the ullage, regardless of interface location. The NAR injector was hot-fired for short durations under Contract NAS3-13328 (Reference 3) and performed well enough to justify pressurization testing in the same $28.3-\mathrm{m}^{3}$ $\left(1,000-\mathrm{ft}^{3}\right)$ tank used for the MDAC tests under Contract NAS3-13306.

This report describes a program in which the work performed under Contract NAS3-13306 was continued under Contract NAS3-14381. Essentially, the same test apparatus was used to evaluate the performance of the advanced MTI injector developed by NAR under Contract NAS3-13328. The tank pressurization performance of the injector was compared with the straight-pipe injector performance from Contract NAS3-13306, and the MTI computer code (H819) was modified to allow injector performance prediction. 


\section{PRESSURIZATION SYSTEM DESIGN}

\section{INJECTOR DESIGN}

The design details of the NAR injector are described in Reference 3. The overall injector configuration is shown in Figure 1 . The injector operates nominally in this way. $G F_{2}$ enters the first stage venturi, a converging-diverging nozzle. The low static $G F_{2}$ pressure in the venturi throat pulls $\mathrm{H}_{2}$ from the vicinity of the second stage venturi, vaporizes and heats the $\mathrm{H}_{2}$ in a heat exchanger, and pumps it through the center tube of the first stage venturi where it combusts with the $\mathrm{GF}_{2}$ at an $\mathrm{O} / \mathrm{F}$ ratio of about $800: 1$. With ambient temperature $\mathrm{GF}_{2}$ inlet conditions, this $\mathrm{O} / \mathrm{F}$ ratio results in a $\mathrm{GF}_{2}$ temperature of about $555^{\circ} \mathrm{K}\left(1,000^{\circ} \mathrm{R}\right)$ entering the second stage. This hot $\mathrm{GF}_{2}$ is again expanded through a converging-diverging nozzle in the second stage venturi to a Mach number of 1.6 , which results in a static $G F_{2}$ pressure at the second stage exit of about 16 percent of the $G F_{2}$ inlet pressure. This low static pressure provides a pressure differential across the annulus at the second stage for pumping $\mathrm{LH}_{2}$ from the tank into the injector. It is clear that the $\mathrm{GF}_{2}$ inlet pressure must be controlled so that the second stage static pressure is less than the $\mathrm{LH}_{2}$ pressure, to provide pumping action. It was found during the Contract NAS3-13328 work that the optimum $G_{2}$ inlet pressure should be 2.25 times the $\mathrm{LH}_{2}$ pressure (tank pressure).

It was determined from results of the NAS3-13306 MTI tests (Reference 2 ) that during test No.'s 2, 4, 8, and 10, tank pressure collapse occurred late in the tests because of insufficient $\mathrm{GF}_{2}$ flow. Analysis of the data indicated that at a tank pressure of $30 \times 10^{4} \mathrm{~N} / \mathrm{m}^{2}$ (43 psia), $\mathrm{LH}_{2}$ outflow rates from 5.2 to $6.7 \mathrm{~kg} / \mathrm{sec}(11.5$ to $14.8 \mathrm{lb} /$ sec), and ullage temperatures from $165^{\circ} \mathrm{K}$ to $299^{\circ} \mathrm{K}\left(298^{\circ} \mathrm{R}\right.$ to $\left.538^{\circ} \mathrm{R}\right)$, 


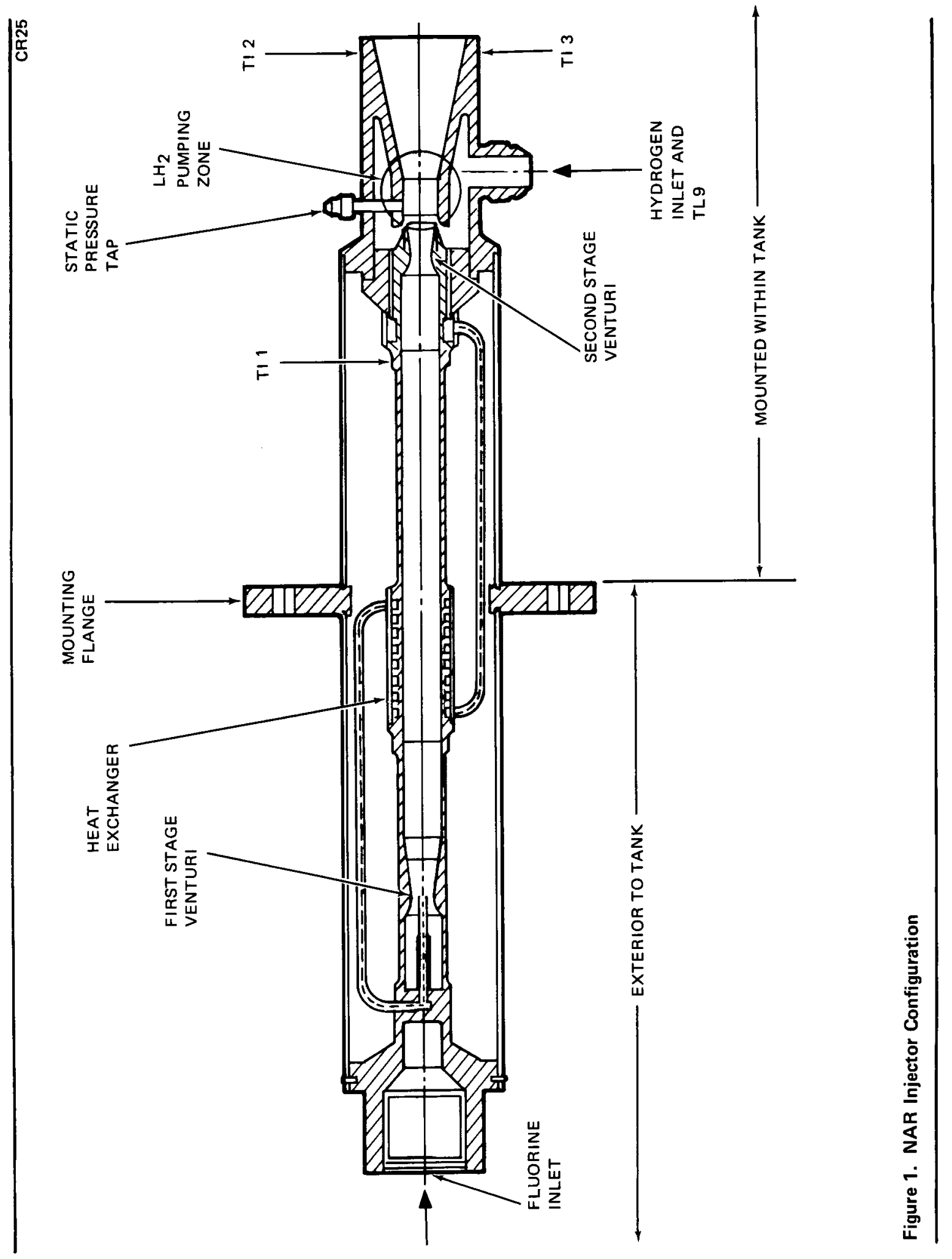


a $\mathrm{GF}_{2}$ flow rate from 0.018 to $0.027 \mathrm{~kg} / \mathrm{sec}(0.04$ to $0.06 \mathrm{lb} / \mathrm{sec})$ was required to maintain tank pressure. The flow characteristics of the injector developed under Contract NAS3-13328 are shown in Figure 2. $\mathrm{GF}_{2}$ inlet pressures in excess of $207 \times 10^{4} \mathrm{~N} / \mathrm{m}^{2}(300 \mathrm{psia})$ would be required with this injector to obtain the requisite $\mathrm{GF}_{2}$ flow rate; therefore, a new scaled-up $\mathrm{GF}_{2}$ injector was obtained from NAR for testing in the $28.3-\mathrm{m}^{3}\left(1,000-\mathrm{ft}^{3}\right)$ test tank.

The new injector design was established by using scale factors to create a higher flow rate version of the NAS3-13328 injector. The design fluorine flow rate was conservatively set at $0.0317 \mathrm{~kg} / \mathrm{sec}$ $(0.07 \mathrm{lb} / \mathrm{sec})$ at $294^{\circ} \mathrm{K}\left(530^{\circ} \mathrm{R}\right)$, with an inlet pressure of $62 \times 10^{4}$ $\mathrm{N} / \mathrm{m}^{2}(90 \mathrm{psia})$. Flow rate is controlled by the first stage sonic venturi of the injector. An effective throat area of $1.89 \times 10^{-5} \mathrm{~m}^{2}$ (0.0288 in. ${ }^{2}$ ) was determined using a flow coefficient of 0.98 . The resulting diametral scale factor for the first stage is 2.11:1. This factor was used throughout the injector for diameter dimensions, except for the second sonic venturi contour where a value of 2.16:1 was used to accommodate anticipated changes in operational temperatures, i.e., the larger injector passages, having less boundary layer effect, were predicted to operate at a slightly higher temperature.

A length scale factor of 2:1 was used in the design. This value was a simplification to facilitate scaling dimensions. The final configuration and dimensional details of the as-built injector are shown in Figure 3 (NAR Drawing AP 71-180). The injector detail parts exposed to GF 2 were fabricated from nickel 200 material (which has excellent resistance to hot $\mathrm{GF}_{2}$ ) using electric discharge machining for the critical dimensions. These details prior to assembly are shown in Figure 4. The detail parts were welded together with all seams exposed to fluorine welded by the electron beam process. Hydrogen jacket welds 


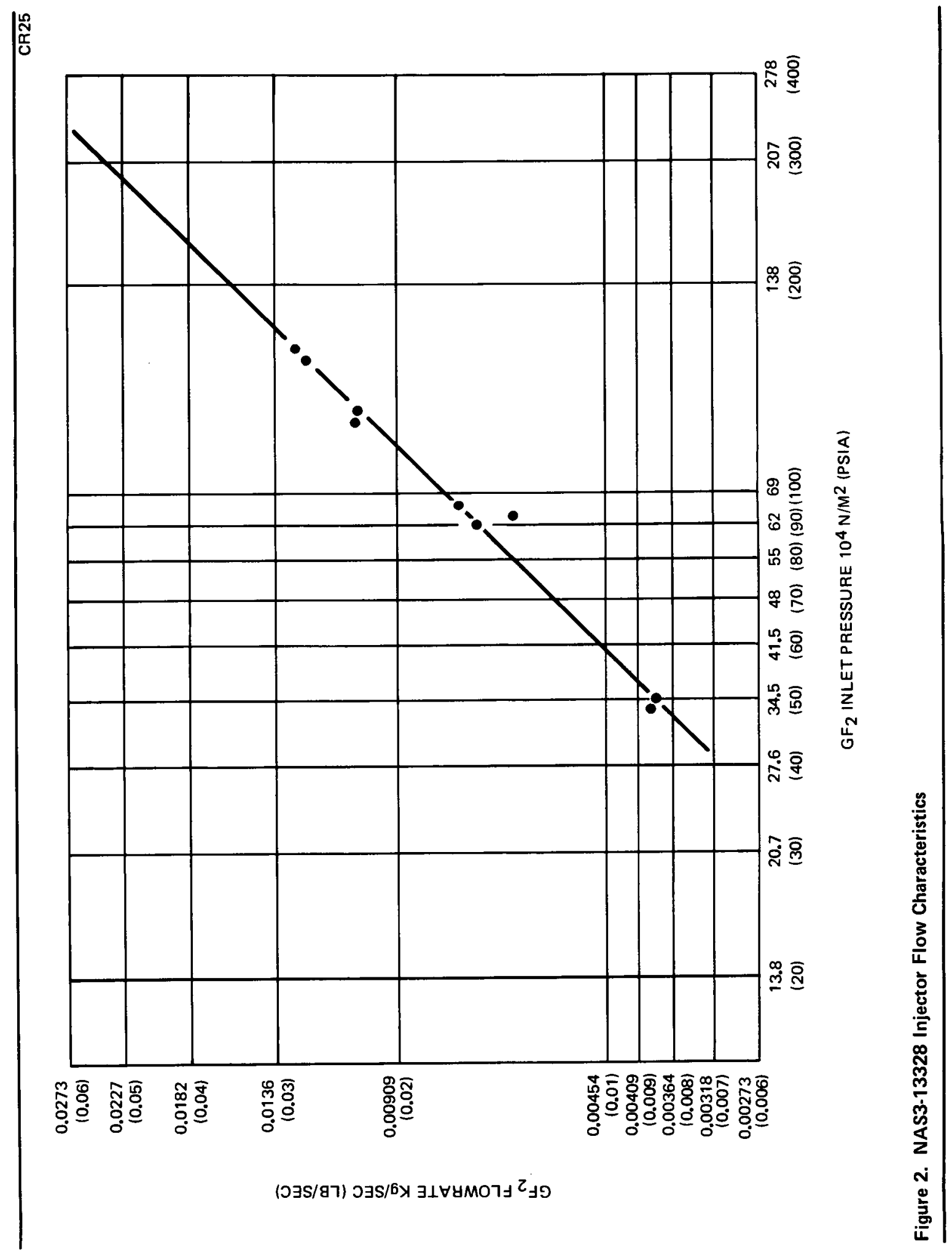



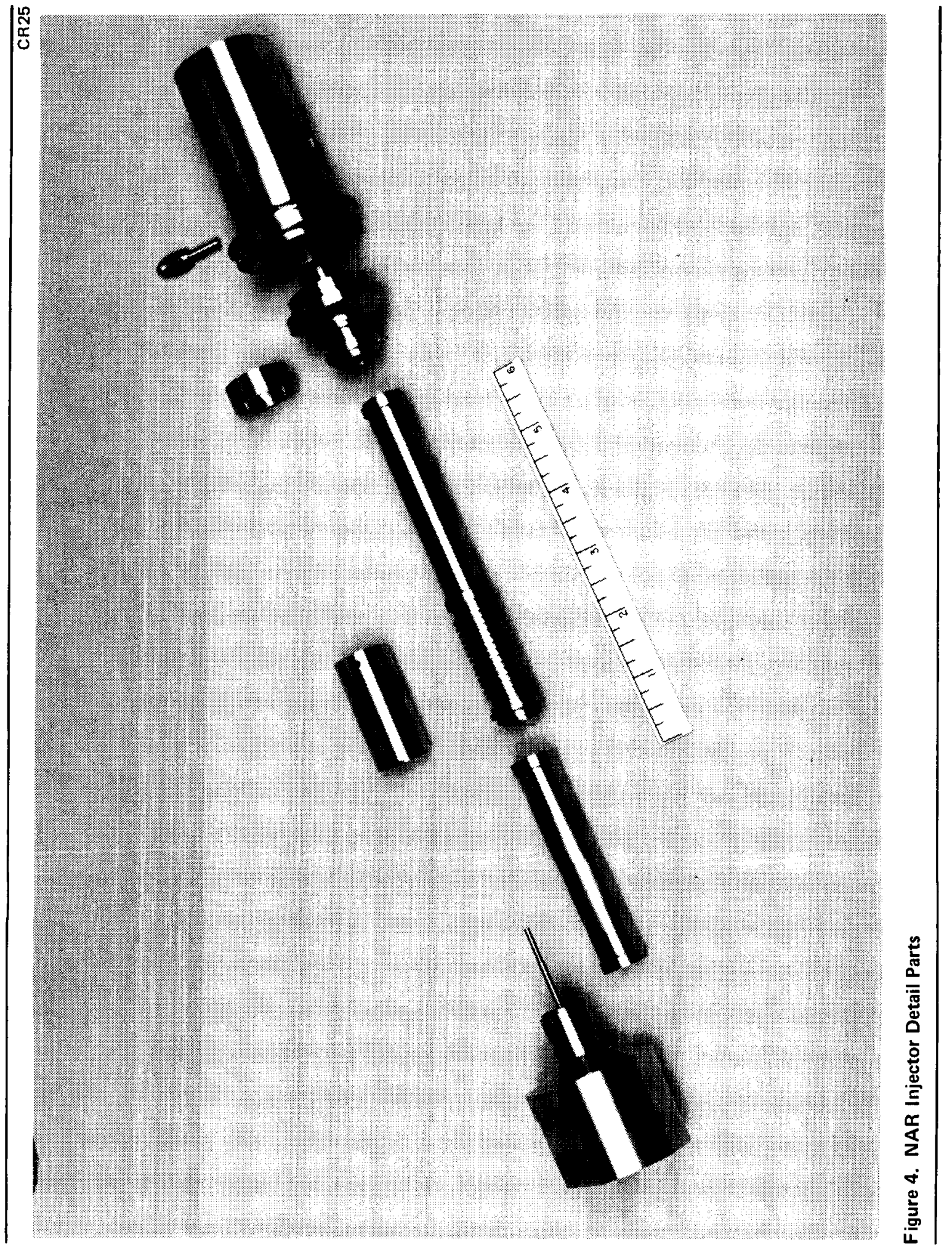
and external welds in the stainless steel outer shell were made using tungsten inert gas (TIG). The small tubes for hydrogen circulation were attached with a fluorine-compatible braze alloy (gold-nickelpalladium alloy, Palniro No. 7). The completed injector is shown in Figure 5 .

The injector configuration was somewhat different from the NAS3-13328 injector in order to adapt the new injector for installation on the Thor test tank. The injector was mounted to an existing flange on the test tank, firing vertically downward. The first stage was situated outside the tank (to reduce thermal effects on first stage performance) while the second stage was situated inside the tank. The second stage nozzle has an annular slot in it to reduce heat transfer across the nozzle to the incoming $\mathrm{LH}_{2}$ flow. At the $\mathrm{GF}_{2}$ inlet, the -023 tube is pinned and free to slide relative to the -003 body thus allowing for thermal expansion of the injector during firing. The injector was designed so the interior of the injector can be purged with helium to prevent cryopumping of air and freezing on the cold second stage. As shown in Figure 1, the injector was instrumented with chromel-alumel thermocouples (TI 1, 2, and 3) external to the first and second stages. The first stage thermocouple wire was routed through a hole in the -015 nozzle diffuser body and the hole was sealed shut with epoxy on assembly. A static pressure tap was provided in the pumping region downstream of the second stage.

Following assembly, the injector was flow-checked with $\mathrm{GN}_{2}$. The computed $\mathrm{GF}_{2}$ flow characteristic of the injector is shown in Figure 6. The $\mathrm{H}_{2}$ pumping characteristics for the NAS3-13328 injector, from Reference 3, are shown in Figure 7 (the scaled-up injector should have identical $\mathrm{LH}_{2}$ flow characteristics). The theoretical performance line shown is at a constant $\mathrm{GF}_{2} / \mathrm{LH}_{2}$ pressure ratio of 2. 25:1. After the $\mathrm{GN}_{2}$ flow calibration, the injector was passivated with $\mathrm{GF}_{2}$ by NAR and delivered to MDAC for test. 

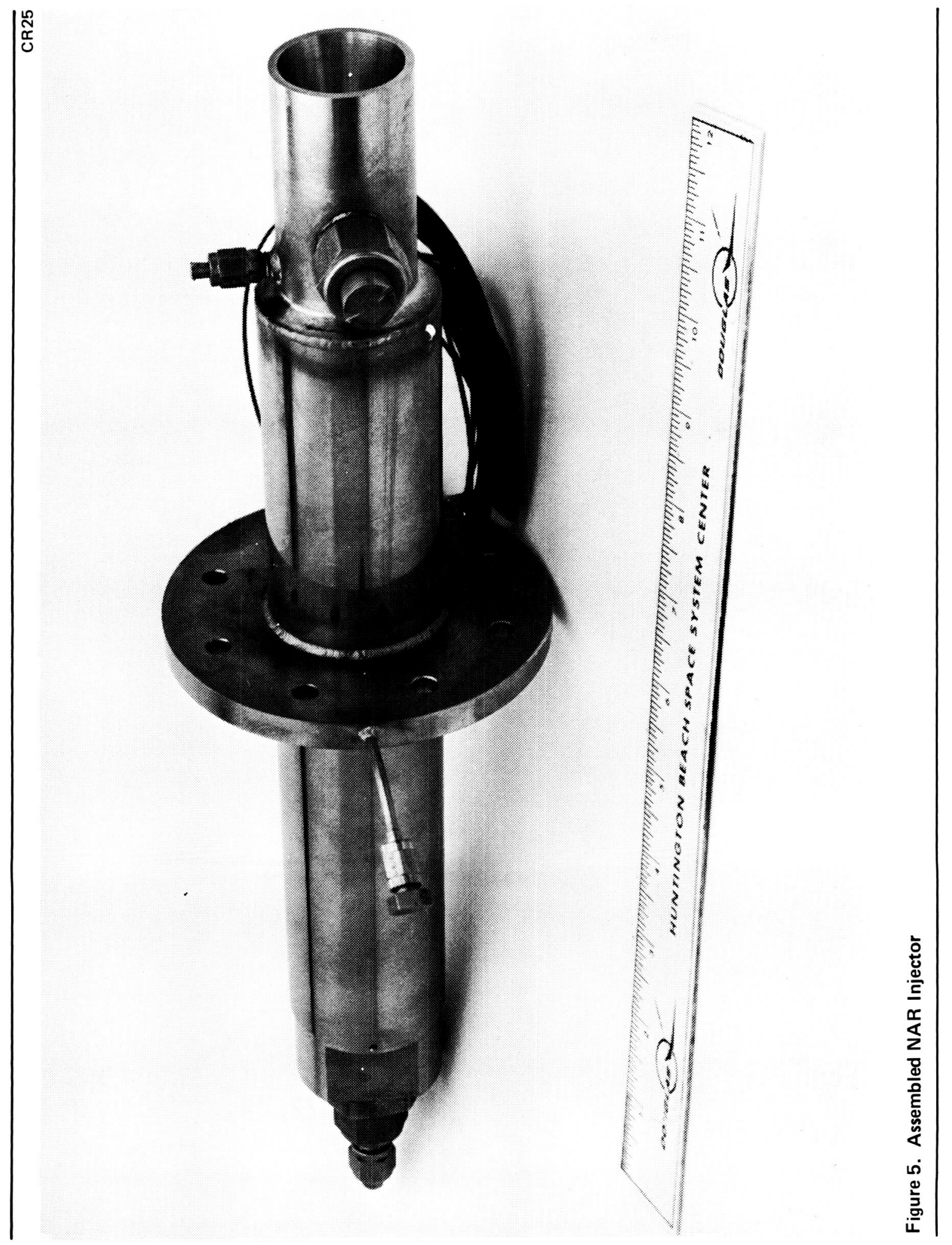

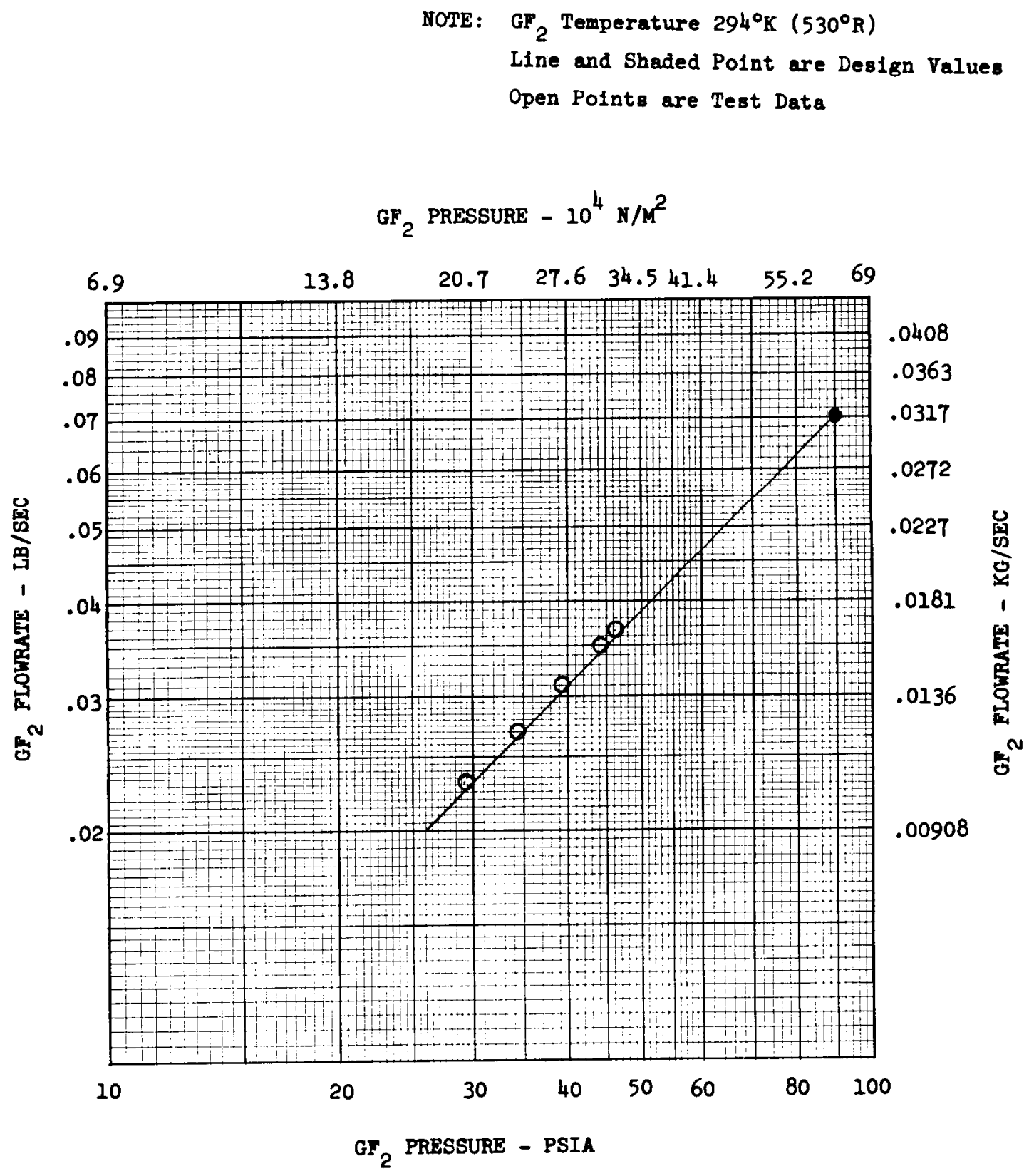

Figure 6. Enlarged NAR Injector Flow Calibration 


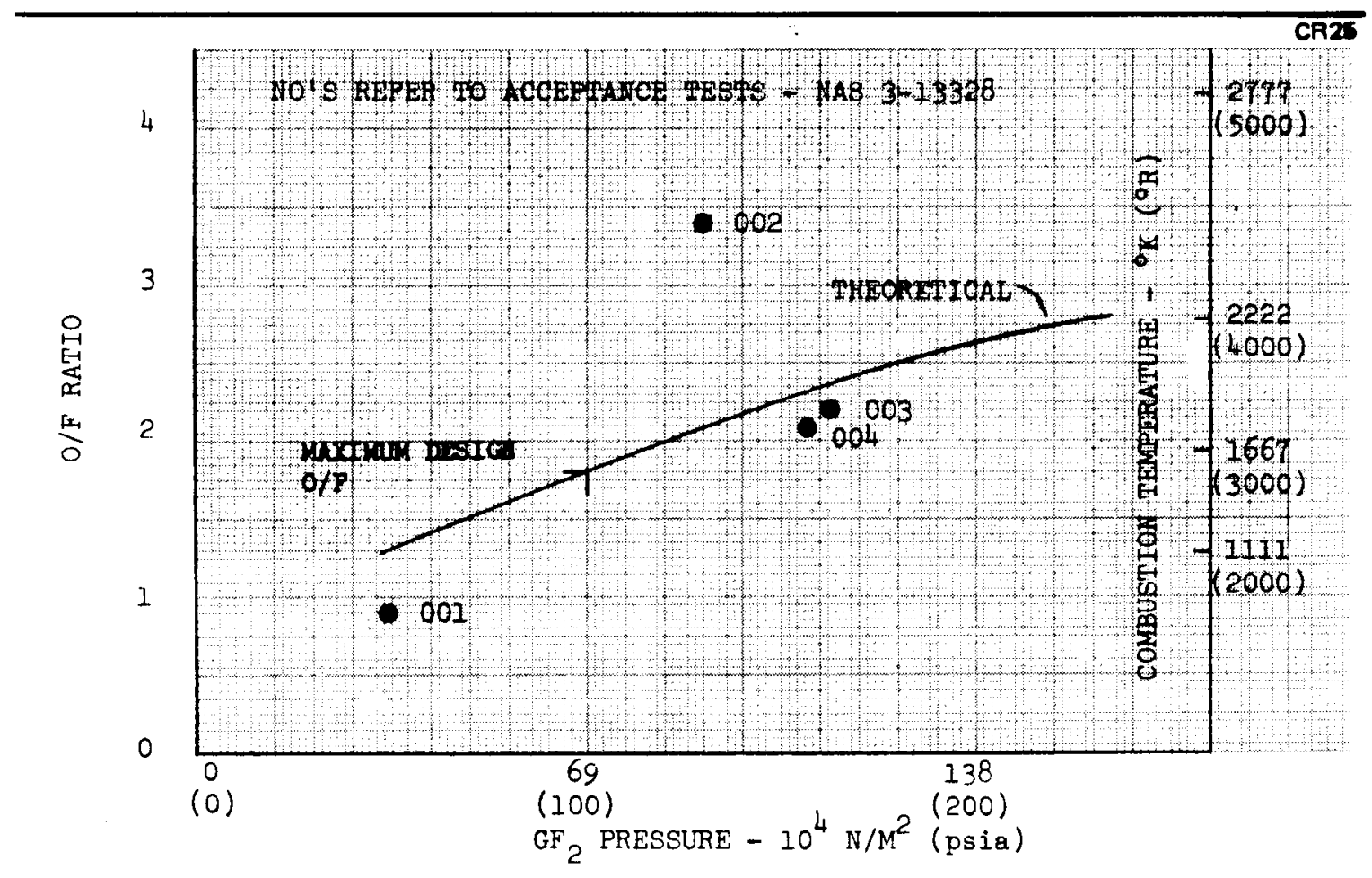

Figure 7. NAR Injector Pumping Characteristics

\section{EXPERIMENTAL SYSTEM DESIGN}

The basic experimental system design (test tank, test facility, instrumentation, etc.) was essentially the same as used for the NAS3-13306 tests (see Reference 2), and is described in detail in this section. Modifications of the MTI system to adapt it to the NAR injector are described in the following section, MTI System Modifications.

Test Tank System

The large-scale flight-weight test tank was a Thor missile oxidizer tank made of 2014-T6 aluminum, internal waffle-pattern milled to a minimum wall thickness of $0.00127 \mathrm{~m}(0.050 \mathrm{in}$.). The tank had a 2. 43-m (95.5-in.) inside diameter, a 5.8-m (228-in.) long cylindrical section, and 0.427-m (16.8-in.) high spherical segment end domes. An insulation system of closed-cell polyurethane foam (Permafoam type CPR385D) with a density of $32 \mathrm{~kg} / \mathrm{m}^{3}\left(2 \mathrm{lb} / \mathrm{ft}^{3}\right)$ and a thermal 
conductivity of $2,075 \mathrm{Joule} / \mathrm{m}-\mathrm{sec}-{ }^{\circ} \mathrm{K}\left(0.16 \mathrm{Btu} / \mathrm{hr}-{ }^{\circ} \mathrm{R}-\mathrm{ft}^{2} / \mathrm{in}\right.$. ) was installed. Assuming an external foam temperature of $272^{\circ} \mathrm{K}\left(30^{\circ} \mathrm{F}\right)$, $0.0635 \mathrm{~m}(2-1 / 2 \mathrm{in}$.) of this foam was calculated to limit the heat flux into the Thor tank to about 94.6 watt $/ \mathrm{m}^{2}\left(30 \mathrm{Btu} / \mathrm{hr}-\mathrm{ft}^{2}\right)$.

The thick foam insulation had become badly cracked from the tank expansion and thermal stresses induced by the MTI pressurization cycles during previous testing. The apparent heat flux to the tank had increased during the NAS3-13306 test program from $2.11 \times 10^{3}$ watt $(2 \mathrm{Btu} / \mathrm{sec})$ to $1.054 \times 10^{4}$ watt $(10 \mathrm{Btu} / \mathrm{sec})$ due to insulation deterioration. The insulation was repaired for the current program by potting the cracks, mechanically fastening the foam to the tank with steel banding straps, enclosing the insulation in a polyethylene purge bag, and purging the insulation with helium. This resulted in no further insulation deterioration and reduced the heat flux to a value of $5.27 \times 10^{3}$ watt $\left(5 \mathrm{Btu} / \mathrm{sec}\right.$ ), which corresponds to $94.6 \mathrm{watt} / \mathrm{m}^{2}$ (30 Btu/hr-ft ${ }^{2}$ ), as determined by tank self-pressurization tests preceding each hot test.

Test Facility System

The Thor test tank installed at the Alpha Complex-Test Stand 1 at the Sacramento Test Center (STC) is shown in Figure 8. The Alpha Complex is shown schematically in Figure 9, which also indicates the facility capacities for purge and pressurization gases. The test facility, described in detail in Reference 2, is quite complex. The important subsystems making up the facility are described below.

The $G_{2}$ supply system was unchanged from the previous program. The baseline $G_{2}$ plumbing was selected to be $0.0254-\mathrm{m}$ (1-in.) diameter tubing routed from three manifolded $G_{2}$ gas cylinders through a prevalve to the injector complex. GHe and $\mathrm{GN}_{2}$ purge valves were also installed. The $\mathrm{GF}_{2}$ cylinder hand valves can be remotely opened. 


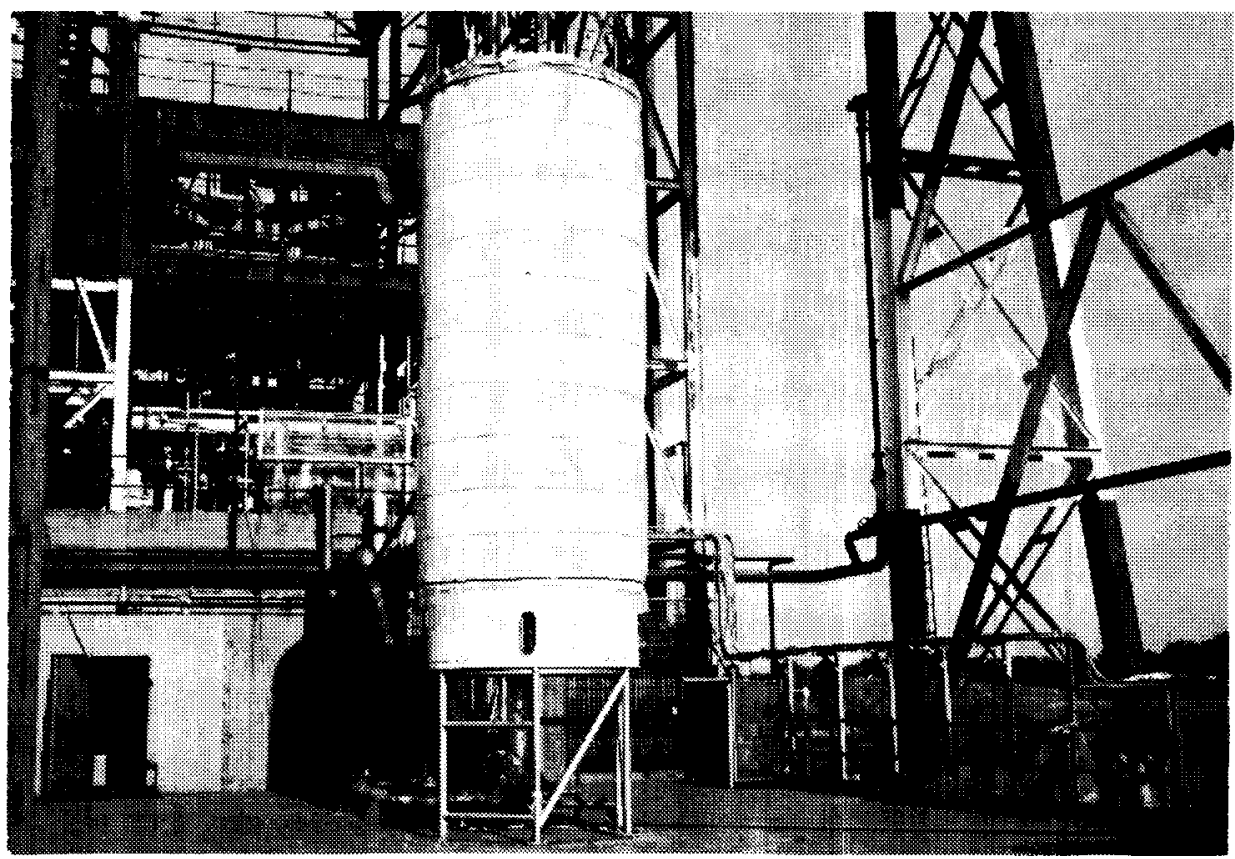

Figure 8. Test Tank Installed at Alpha Test Stand

The $\mathrm{LH}_{2}$ was filled and emptied from the tank bottom through the main $\mathrm{LH}_{2}$ outflow valve, a $0.1524-\mathrm{m}$ (6-in.) diameter Annin valve with a Domotor operator. This valve could be set at any position from fullopen to closed and was used to control the $\mathrm{LH}_{2}$ outflow rate to preset values. The $\mathrm{LH}_{2}$ flow was dumped through the facility $\mathrm{LH}_{2}$ valve complex (sled) and out the 0.1524-m (6-in.) diameter facility vent line, where it was burned. The tank $\mathrm{GH}_{2}$ vent valve was also located in the vicinity of the $\mathrm{LH}_{2}$ valve sled, with the result that the tank vent line was about $23 \mathrm{~m}$ (75 ft) long. The tank vent line can be seen in the side view of the Thor tank in Figure 10 . The vent line was supported by the vertical beam which also provided support for all plumbing lines and wiring to the top of the tank; the pressure switches were also mounted at the top of the beam (see MTI system design in the next section). This large vent line contributed $0.566 \mathrm{~m}^{3}\left(20 \mathrm{ft}^{3}\right)$ to the tank ullage volume, the effects of which are compensated for in 


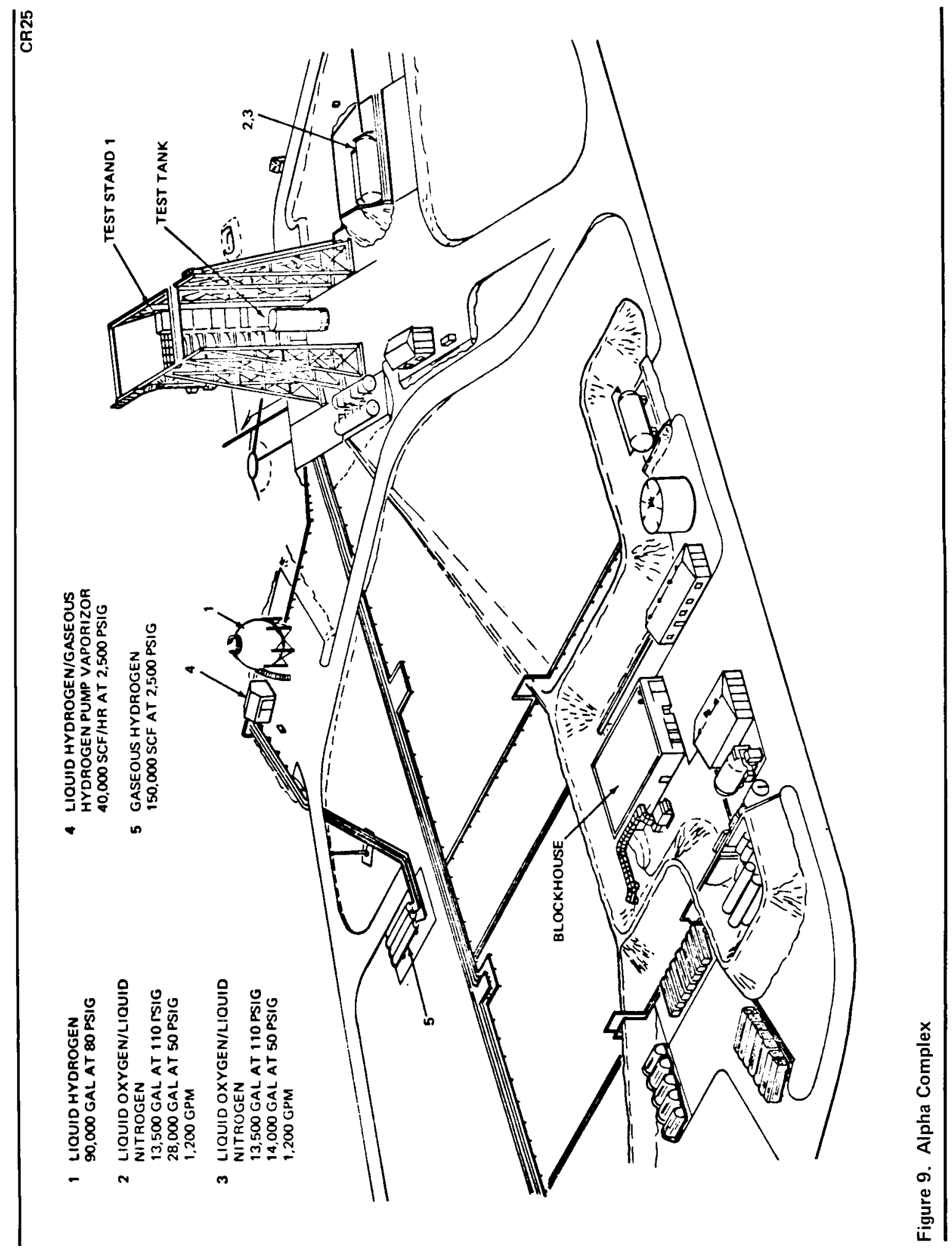




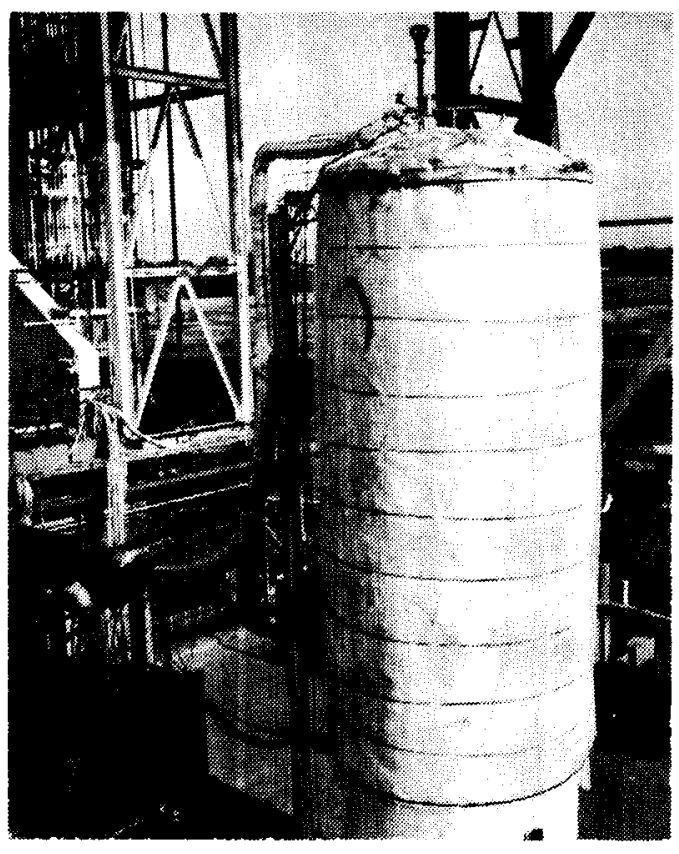

Figure 10. Side View of Test Tank

the analysis of the experimental results. All cryogenic $\mathrm{H}_{2}$ lines were batted, wrapped, and helium-purged to resist cryopumping. Helium pressurization through a diffuser for $\mathrm{LH}_{2}$ offloading was available if the situation required.

The extremely complex subsystem which was used to sample for $\mathrm{HF}$ in the effluent $\mathrm{LH}_{2}$ in the NAS3-13306 tests was eliminated for this program. No HF sampling was performed.

The previous work indicated that HF would plate out on the internal tank surfaces. Although frozen HF is not particularly reactive, following MTI pressurization the tank ullage and walls could be warm enough to cause the HF to liquify (or the tank could warm up between test days). Liquid anhydrous $H F$ is quite corrosive and could attack the tank material, instrumentation, wiring, etc. $\mathrm{A} \mathrm{GN}_{2}$ hot purge 
system was used to purge out and completely warm up the tank to remove $\mathrm{HF}$ between test days. The tank was warmed up to about $311^{\circ} \mathrm{K}\left(100^{\circ} \mathrm{F}\right)$. As $\mathrm{HF}$ boils at about $292^{\circ} \mathrm{K}\left(65^{\circ} \mathrm{F}\right)$, the warming proved quite successful in eliminating the corrosive effects of $\mathrm{HF}$.

\section{Instrumentation System}

The instrumentation and data acquisition equipment used in the test program was basically that used for the previous NAS3-13306 tests, except for some failed temperature transducers which were not replaced. The previous tests utilized several tank-wall-mounted heat flux and temperature sensors at each of several axial locations in the tank to provide data on radial nonuniformities in the ullage gas. No significant nonuniformities were found (see Reference 2), and further, several of the fluxmeters were damaged by overheating. It was therefore decided to provide at least one fluxmeter/wall gas temperature installation at each principal axial location, but not to replace thermal instrumentation beyond that. The location of all thermal sensors (to be used in measuring the temperatures of the ullage gas, $\mathrm{LH}_{2}$, and tank wall, as well as the local heat flux) is shown in Figure 11 , which is an exploded view from inside the tank. The instruments to measure ullage gas (TU) and liquid temperature (TL) were mounted on a vertical probe situated at the half-radius of the tank. These platinum resistance sensors were Thermal Systems, Inc., type $1080-1\left(1,380 \Omega\right.$ at $273^{\circ} \mathrm{K}$ $\left.\left[32^{\circ} \mathrm{F}\right]\right)$, and were situated at $0.305-\mathrm{m}(\mathrm{l}-\mathrm{ft})$ intervals on the probe. Essentially, every third sensor was set to measure $\mathrm{LH}_{2}$ temperature. These generally coincided with the location of the level sensors, and at the basic tank levels of 95,50 and 10 percent (stations 384, 492, and 588), the $\mathrm{LH}_{2}$ temperature platinum sensors provided the reference temperature for the thermopile installations. Seven-element thermopile assemblies were situated on the vertical probe above stations 384,492 , and 588 to determine the initial conditions at the interface (as shown in Figure 12). The thermopile assemblies were 


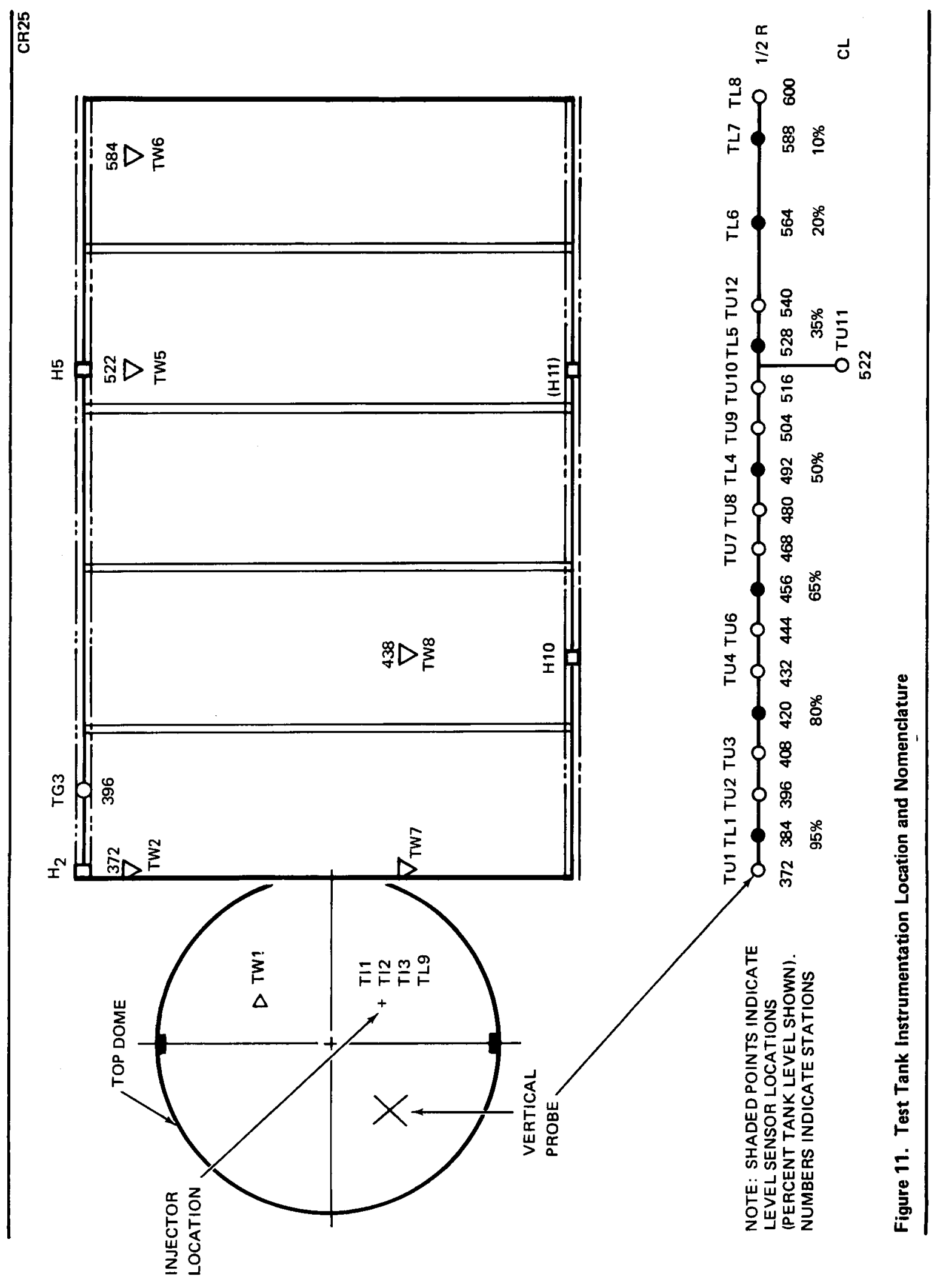




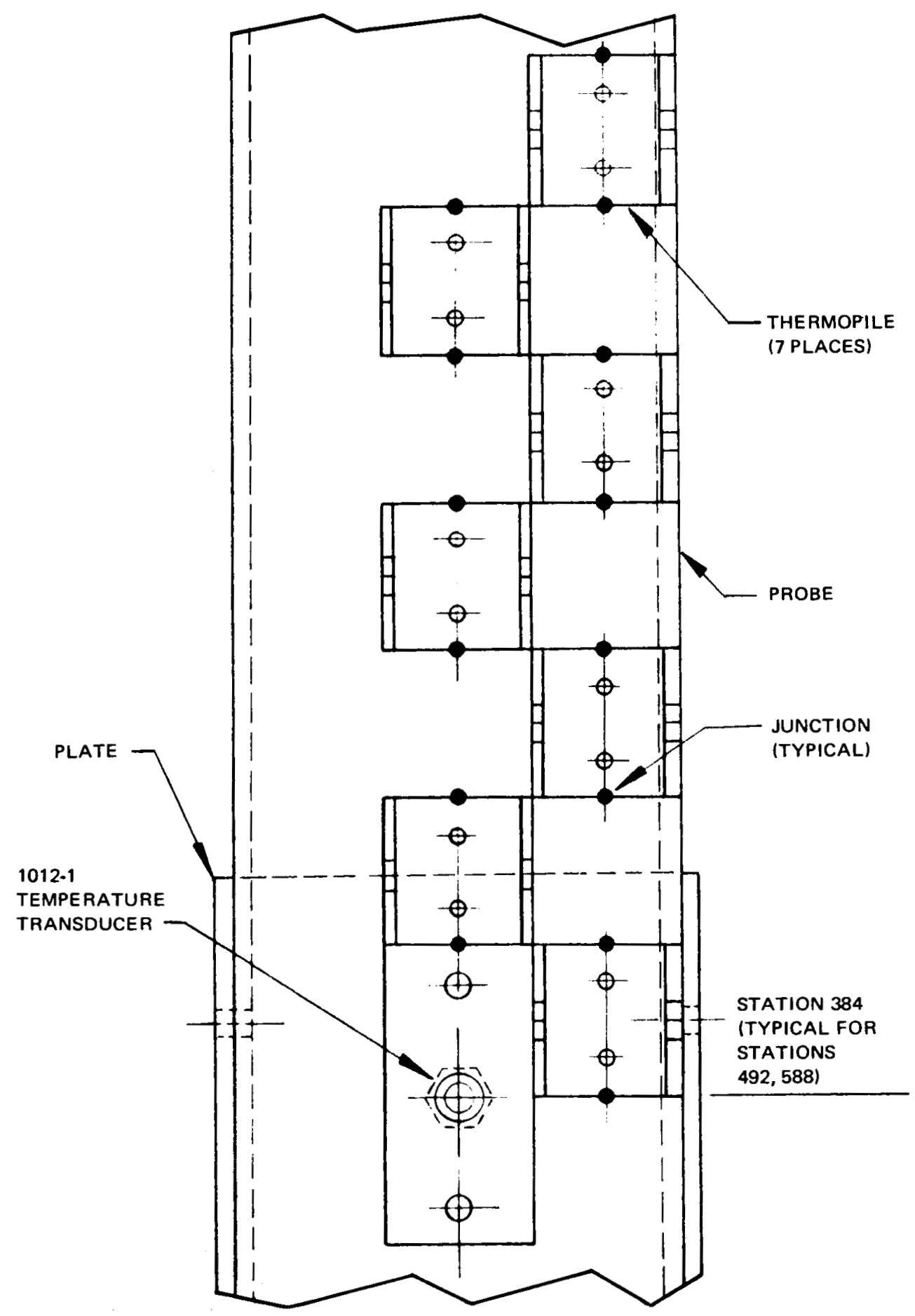

Figure 12. Thermopile Assembly 
configured as shown in Figure 13. Each thermopile element had six chromel-constantan junctions (three at one level and three at a level $0.0254 \mathrm{~m}$ [l in.] below) and two null junctions of copper-chromel. The lower junctions of each element were level with the upper junctions of the element below, with the lower junctions of the lowest element level with the $\mathrm{LH}_{2}$ temperature sensor at that station. The thermopiles measure the temperature difference between the junction levels $0.0254 \mathrm{~m}$ ( 1 in.) apart. Level sensors were also situated on the vertical probe. These were Ohmite Little Devil $1 \mathrm{~K} \Omega$ resistors, overdriven to heat up (and change resistance) rapidly when the surrounding medium changed from $\mathrm{LH}_{2}$ to gas. Two level sensors were situated $0.0254 \mathrm{~m}$ ( $1 \mathrm{in.}$ ) apart at the basic liquid fill levels (95+, 95, $50+, 50,10+$, and 10 percent). The initial liquid level was kept between these sensors which were $0.0254 \mathrm{~m}$ ( 1 in.) apart. These sensors, plus level sensors at 80,65, 35, and 20-percent liquid levels, were used for $\mathrm{LH}_{2}$ outflow rate measurement. This technique was used successfully on the previous test program.

The tank wall temperatures (TW) were measured at six (out of the original eight) locations, as shown in Figure 11 . The platinum resistance sensors used were Thermal Systems, Inc. type 5001-19 (500 at $\left.273^{\circ} \mathrm{K}\left[32^{\circ} \mathrm{F}\right]\right)$ which were bonded to the outside of the tank wall under the foam insulation.

The heat flux and local heat transfer coefficients inside the tank were measured using commercially fabricated thermal flux meters. This meter, made by International Thermal Instrument Company, is a polyimide glass plate with plated thermopiles on each surface.

The thermopiles would directly measure the $\Delta \mathrm{T}$ across the plate and produce a multimillivolt signal proportional to heat flux. These devices were completely compatible with the cryogenic environment 

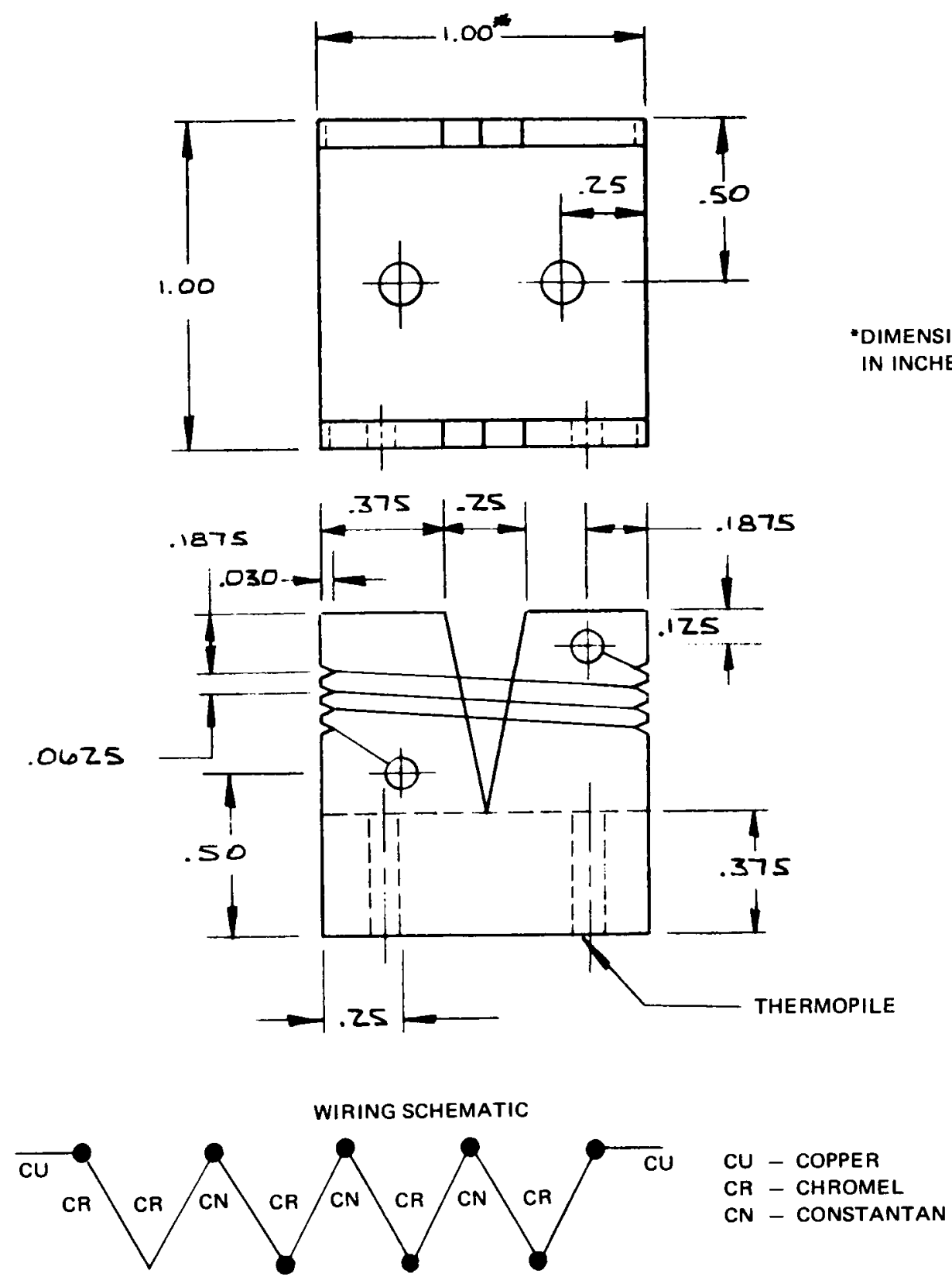

Figure 13. Thermopile Element Detail 
and have been used on many $\mathrm{LH}_{2}$ research programs. The instruments are individually calibrated to an accuracy of 1 percent. They were supplied clad with stainless steel to protect the glass from $\mathrm{HF}$ attack.

These fluxmeters gave consistent data in the previous test program. A typical fluxmeter installation is shown in Figure 14. The fluxmeters were bonded to the aluminum channel with a thin coating of Dow-Corning 731 RTV Silastic. The fluxmeter surface temperature was measured with a Thermal Systems, Inc. type 5001-19 platinum resistance sensor bonded to the front of the fluxmeter with Minnesota Mining and Manufacturing Co. EC3515 epoxy. The gas temperature in the vicinity of the fluxmeter was measured with a Thermal Systems, Inc. type 1012-1 platinum resistance sensor. These also provided a comparison with the gas temperature measured at the vertical probe at the tank half-radius. The local heat transfer coefficient was determined by dividing the heat flux by the temperature difference between the gas and fluxmeter. The fluxmeters were situated in the tank as shown by the $\mathrm{H}$ nomenclature in Figure 11 .

Figure 15 shows a view looking upward inside the Thor tank prior to testing and indicates the relative position of the instrumentation in the tank. The NAR injector is installed at right center; note the vacuum jacketed $\mathrm{LH}_{2}$ feedline leading to the injector (see MTI system modifications in the next section). The injector thermocouple wires are visible. The injector thermocouples were chromel-alumel with the reference junction situated at the bottom of the tank where it was immersed in $\mathrm{LH}_{2}$ during testing.

The fluxmeter output and all other temperatures were recorded on either Leeds and Northrup Speedomax H (Model 1022) strip charts, on Minneapolis-Honeywell Electronic 17 (Model 1070) strip charts, or on 


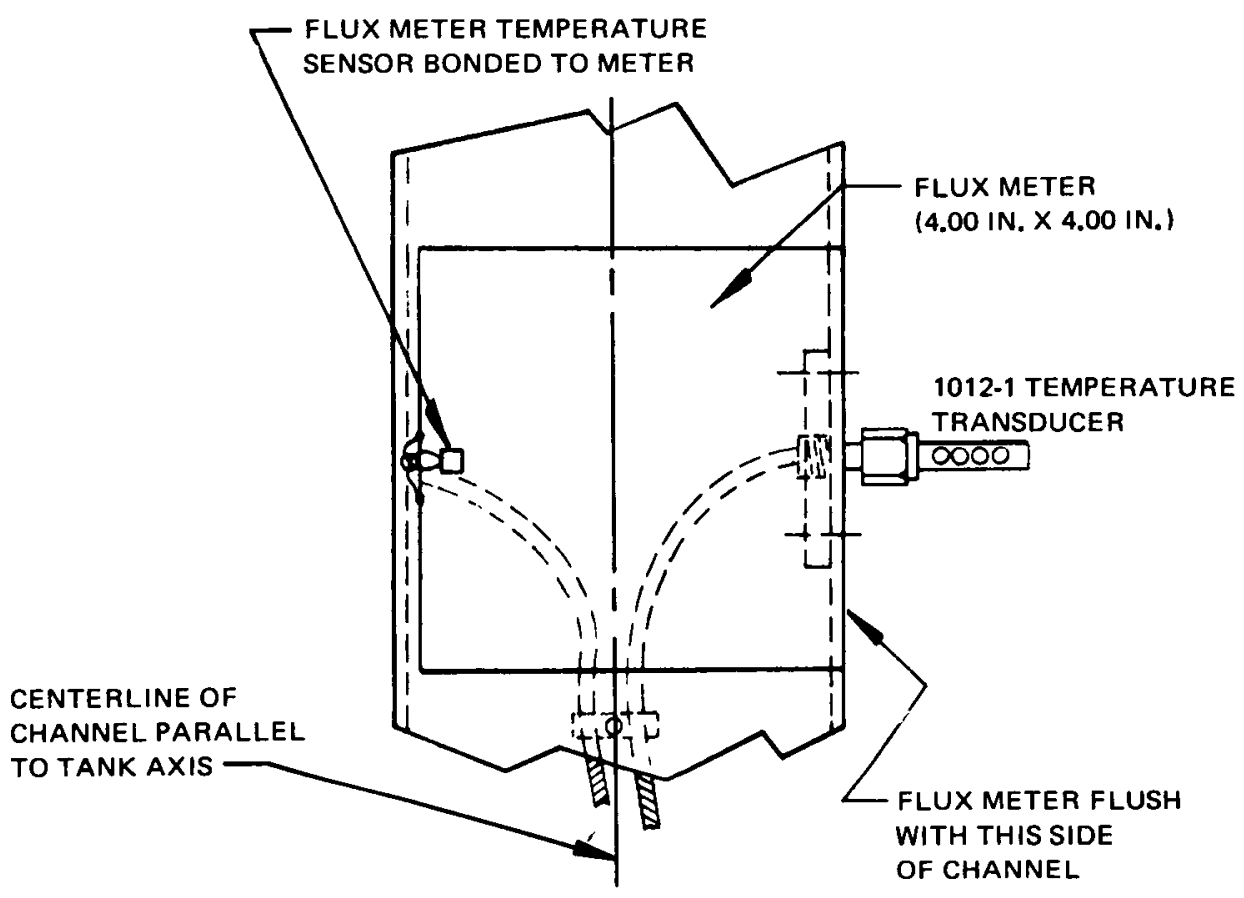

Figure 14. Fluxmeter Installation

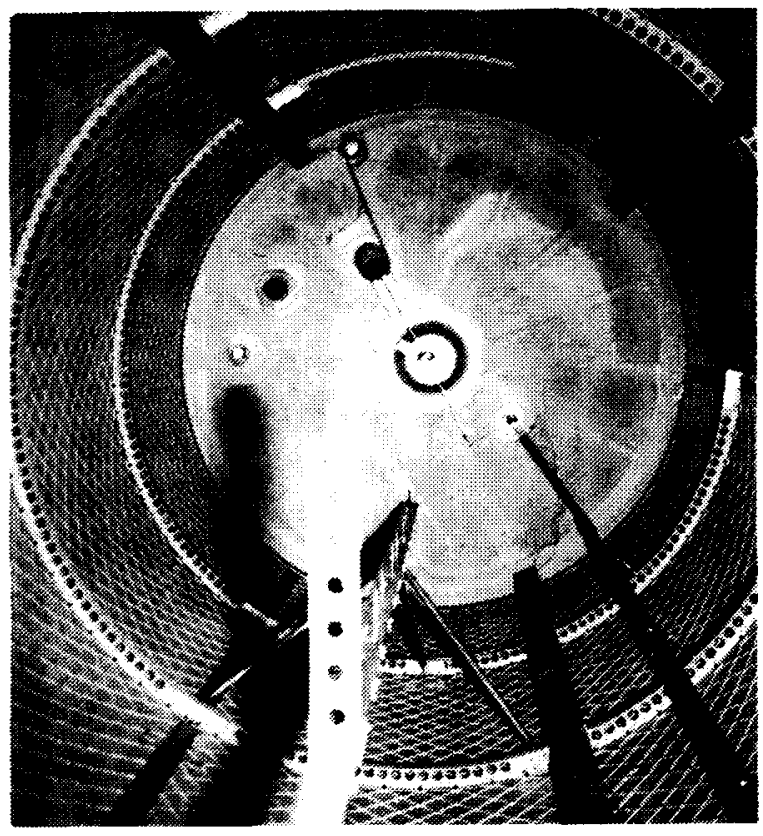

CR25

Figure 15. Interior View of Test Tank 
the Applied Electronics type 340-700 Pulse Duration Modulation (PDM) system. Sufficient parameters were recorded continuously on the strip charts to evaluate test results without performing the complete automated data reduction built into the PDM system. The temperature data on strip charts included two fluxmeter installations (also recorded on PDM), three tank wall temperatures, and essentially every other ullage temperature sensor on the vertical probe.

The complete temperature-related instrumentation list, showing location, function, working range, and data acquisition method, is shown in Table 1. Timing pulses were supplied by an Astrodata Model DAl12-38 Time Code Generator. The relay energize signals from the MTI control system were recorded on a Sanborn Model 125 Event Recorder.

All system pressures were measured with strain-gage-type pressure transducers. The test tank ullage pressure was measured with two fully redundant Owens Labs type PS-254-3Al0-TA $\left(0-345 \times 10^{3} \mathrm{~N} / \mathrm{m}^{2}\right.$ [0-50 psia]) pressure transducers. The $\mathrm{GF}_{2}$ flow rate was determined by the regulated $G_{2}$ pressure to the critical-flow injector (see Figure 6). The $\mathrm{GF}_{2}$ pressure upstream of the injector was measured with a Statham PA347-TC-100-350 (0-6.9 x $\left.10^{5} \mathrm{~N} / \mathrm{m}^{2}[0-100 \mathrm{psia}]\right)$ transducer. A backup $G_{2}$ flow rate measurement was made with a calibrated orifice $(0.00635-\mathrm{m}$ [0.25-in.] diameter) in the GF 2 flow line just upstream of the injector valve. The $\mathrm{GF}_{2}$ pressure upstream of the orifice (essentially $\mathrm{GF}_{2}$ cylinder pressure) was measured with a Statham type PA822-500 $\left(0-3450 \times 10^{3} \mathrm{~N} / \mathrm{m}^{2}[0-500 \mathrm{psia}]\right)$ transducer and the pressure drop across the orifice with a Statham type PM280-TC- $\pm 5-350\left( \pm 34.5 \times 10^{3} \mathrm{~N} / \mathrm{m}^{2}[ \pm 5\right.$ psia $\left.]\right)$ transducer. The $\mathrm{GF}_{2}$ temperature upstream of the orifice was measured with a Thermal Systems, Inc. type 1080-1 platinum sensor. The static pressure in the injector second stage was measured with a Statham PA285-TC-50-350 
Table 1

INSTRUMENTATION DATA (Page 1 of 4)

\begin{tabular}{|c|c|c|c|c|c|c|}
\hline No. & & $\mathrm{P} / \mathrm{N}$ & $\begin{array}{l}\text { Station } \\
\text { Location }\end{array}$ & $\begin{array}{c}\text { Function } \\
(\mathrm{T}=\text { Temp })\end{array}$ & $\begin{array}{l}\text { Range } \\
{ }^{\circ} K\left({ }^{\circ} R\right)\end{array}$ & Data \\
\hline $\begin{array}{r}\mathrm{H} 2 \\
\mathrm{TG} 2 \\
\mathrm{TQ2} \\
\mathrm{Q} 2\end{array}$ & $\begin{array}{l}\text { TS1 } \\
\text { TS1 } \\
1 \text { T1 }\end{array}$ & $\begin{array}{l}1012-1 \\
5001-19 \\
\text { "A" }\end{array}$ & 372 & $\begin{array}{l}\text { Heat Trans Coef } \\
\text { Ullage Gas } \mathrm{T} \\
\text { Flux Meter } \mathrm{T} \\
\text { Flux }\end{array}$ & $\begin{array}{ll}20-556 & (36-1,000) \\
20-556 & (36-1,000)\end{array}$ & $\begin{array}{l}\text { S/C \& } \\
\text { PDM }\end{array}$ \\
\hline $\begin{array}{l}(\mathrm{H} 3) \\
\text { TG3 }\end{array}$ & TSl & $1012-1$ & 396 & $\begin{array}{l}\text { (Heat Trans Coef) } \\
\text { Ullage Gas } \mathrm{T}\end{array}$ & $20-556(36-1,000)$ & PDM \\
\hline $\begin{array}{l}\text { H5 } \\
\text { TG5 } \\
\text { TQ5 } \\
\text { Q5 }\end{array}$ & $\begin{array}{l}\text { TS1 } \\
\text { TS1 } \\
1 \text { T } 1\end{array}$ & $\begin{array}{l}1012-1 \\
5001-19 \\
\text { "A" }\end{array}$ & 522 & $\begin{array}{l}\text { Heat Trans Coef } \\
\text { Ullage Gas T } \\
\text { Flux Meter } \mathrm{T} \\
\text { Flux }\end{array}$ & $\begin{array}{ll}20-556 & (36-1,000) \\
20-556 & (36-1,000)\end{array}$ & PDM \\
\hline $\begin{array}{l}\mathrm{H} 10 \\
\text { TG10 } \\
\text { TQ10 } \\
\text { Q10 }\end{array}$ & $\begin{array}{l}\text { TS1 } \\
\text { TS1 } \\
1 \text { T1 }\end{array}$ & $\begin{array}{l}1012-1 \\
5001-19 \\
\text { "A" }\end{array}$ & 438 & $\begin{array}{l}\text { Heat Trans Coef } \\
\text { Ullage Gas } \bar{I} \\
\text { Flux Meter } T \\
\text { Flux }\end{array}$ & $\begin{array}{ll}20-556 & (36-1,000) \\
20-556 & (36-1,000)\end{array}$ & $\begin{array}{l}\text { S/C \& } \\
\text { PDM }\end{array}$ \\
\hline $\begin{array}{l}(\mathrm{H} 11) \\
\text { TG11 } \\
\text { Q11 }\end{array}$ & $\begin{array}{l}\text { TS1 } \\
1 \mathrm{Tl}\end{array}$ & $\begin{array}{l}1012-1 \\
\text { "A" }\end{array}$ & 522 & $\begin{array}{l}\text { (Heat Trans Coef } \\
\text { Ullage Gas T } \\
\text { Flux }\end{array}$ & $20-556(36-1,000)$ & $\mathrm{PDM}$ \\
\hline TW1 & TSI & $5001-19$ & Top Dome & Tank Wall $\mathrm{T}$ & $20-389(36-700)$ & $\mathrm{S} / \mathrm{C}$ \\
\hline TW2 & $\mathrm{TS} 1$ & $5001-19$ & 372 & Tank Wall $\mathrm{T}$ & $20-389(36-700)$ & PDM \\
\hline TW5 & $\mathrm{TS} 1$ & $5001-19$ & 522 & Tank Wall $\mathrm{T}$ & $20-389(36-700)$ & $\mathrm{S} / \mathrm{C}$ \\
\hline TW6 & TS1 & $5001-19$ & 584 & Tank Wall T & $20-389(36-700)$ & $\mathrm{PDM}$ \\
\hline TW7 & TS1 & $5001-19$ & 372 & Tank Wall $\mathrm{T}$ & $20-389(36-700)$ & $\mathrm{PDM}$ \\
\hline TW8 & $\mathrm{TSl}$ & $5001-19$ & 438 & Tank Wall $\mathrm{T}$ & $20-389(36-700)$ & PDM \\
\hline TUl & $\mathrm{TS} 1$ & $1080-1$ & $372-1 / 2 \mathrm{R}$ & Ullage Gas $\mathrm{T}$ & $20-556(36-1,000)$ & $\mathrm{S} / \mathrm{C}$ \\
\hline TU2 & TSl & $1080-1$ & $396-1 / 2 R$ & Ullage Gas $\mathrm{T}$ & $20-556(36-1,000)$ & $\mathrm{S} / \mathrm{C}$ \\
\hline TU3 & TSI & $1080-1$ & $408-1 / 2 \mathrm{R}$ & Ullage Gas $\mathrm{T}$ & $20-556(36-1,000)$ & PDM \\
\hline TU4 & TSl & $1080-1$ & $432-1 / 2 \mathrm{R}$ & Ullage Gas $\mathrm{T}$ & $20-556(36-1,000)$ & $\mathrm{S} / \mathrm{C}$ \\
\hline
\end{tabular}


Table 1

INSTRUMENTATION DATA (Page 2 of 4)

\begin{tabular}{|c|c|c|c|c|c|c|}
\hline No. & $P / N$ & $\begin{array}{l}\text { Station } \\
\text { Location }\end{array}$ & $\begin{array}{c}\text { Function } \\
(\mathrm{T}=\text { Temp })\end{array}$ & & $\begin{array}{l}\text { Range } \\
\mathrm{K}\left({ }^{\circ} \mathrm{R}\right)\end{array}$ & Data \\
\hline TU6 & TSl 1080-1 & $444-1 / 2 \mathrm{R}$ & Ullage Gas $\mathrm{T}$ & $20-556$ & $(36-1,000)$ & PDM \\
\hline TU7 & TS1 $1080-1$ & $468-1 / 2 \mathrm{R}$ & Ullage Gas T & $20-556$ & $(36-1,000)$ & $\mathrm{S} / \mathrm{C}$ \\
\hline TU8 & TS1 $1080-1$ & $480-1 / 2 \mathrm{R}$ & Ullage Gas T & $20-556$ & $(36-1,000)$ & $\mathrm{PDM}$ \\
\hline TU9 & TS1 1080-1 & $504-1 / 2 \mathrm{R}$ & Ullage Gas $\mathrm{T}$ & $20-556$ & $(36-1,000)$ & $\mathrm{S} / \mathrm{C}$ \\
\hline TU10 & TS1 $1080-1$ & $516-1 / 2 \mathrm{R}$ & Ullage Gas T & $20-556$ & $(36-1,000)$ & PDM \\
\hline TU11 & TS1 $1080-1$ & $522-C I$ & Ullage Gas T & $20-556$ & $(36-1,000)$ & $\mathrm{S} / \mathrm{C}$ \\
\hline TU12 & TS1 $1012-1$ & $540-1 / 2 \mathrm{R}$ & Ullage Gas T & $20-556$ & $(36-1,000)$ & $\mathrm{S} / \mathrm{C}$ \\
\hline TLl & TS1 $1012-1$ & $384-1 / 2 \mathrm{R}$ & Liquid $\mathrm{T}$ & $20-33$ & $(36-60)$ & PDM \\
\hline TL4 & TS1 $1012-1$ & $492-1 / 2 R$ & Liquid $T$ & & $(36-60)$ & PDM \\
\hline TL5 & TS1 $1080-1$ & $528-1 / 2 \mathrm{R}$ & Liquid $T$ & & $(36-60)$ & PDM \\
\hline TL6 & TS1 $1080-1$ & $564-1 / 2 \mathrm{R}$ & Liquid $\mathrm{T}$ & & $(36-60)$ & PDM \\
\hline TL7 & TS1 $1012-1$ & $588-1 / 2 \mathrm{R}$ & Liquid $\mathrm{T}$ & & $(36-60)$ & PDM \\
\hline TL8 & TS1 1012-1 & $600-1 / 2 \mathrm{R}$ & Liquid $\mathrm{T}$ & $20-33$ & $(36-60)$ & $S / C$ \\
\hline TL9 & $7882210-505$ & $\begin{array}{l}\text { Injector } \\
\mathrm{LH}_{2} \text { Line }\end{array}$ & $\mathrm{LH}_{2}$ Supply $\mathrm{T}$ & $20-89$ & $(36-160)$ & $\mathrm{S} / \mathrm{C}$ \\
\hline TPl 1 & $\begin{array}{l}\text { MDAC } \\
\text { Thermopile }\end{array}$ & $384-1 / 2 \mathrm{R}$ & Interface $T$ & & & PDM \\
\hline TPl2 & $\begin{array}{l}\text { MDAC } \\
\text { Thermopile }\end{array}$ & $383-1 / 2 \mathrm{R}$ & Interface $T$ & & & PDM \\
\hline TP1 3 & $\begin{array}{l}\text { MDAC } \\
\text { Thermopile }\end{array}$ & $382-1 / 2 R$ & Interface $T$ & & & PDM \\
\hline TP1 4 & $\begin{array}{l}\text { MDAC } \\
\text { Thermopile }\end{array}$ & $381-1 / 2 R$ & Interface $T$ & & & PDM \\
\hline TPl 5 & $\begin{array}{l}\text { MDAC } \\
\text { Thermopile }\end{array}$ & $380-1 / 2 \mathrm{R}$ & Interface $\mathrm{T}$ & & & PDM \\
\hline
\end{tabular}


Table 1

INSTRUMENTATION DATA (Page 3 of 4)

\begin{tabular}{|c|c|c|c|c|c|}
\hline No. & $\mathrm{P} / \mathrm{N}$ & $\begin{array}{l}\text { Station } \\
\text { Location }\end{array}$ & $\begin{array}{c}\text { Function } \\
(\mathrm{T}=\text { Temp })\end{array}$ & $\begin{array}{l}\text { Range } \\
{ }^{\circ} \mathrm{K}\left({ }^{\circ} \mathrm{R}\right)\end{array}$ & Data \\
\hline TPl 6 & $\begin{array}{l}\text { MDAC } \\
\text { Thermopile }\end{array}$ & $379-1 / 2 \mathrm{R}$ & Interface $T$ & & PDM \\
\hline $\mathrm{TP} 17$ & $\begin{array}{l}\text { MDAC } \\
\text { Thermopile }\end{array}$ & $378-1 / 2 \mathrm{R}$ & Interface $T$ & & PDM \\
\hline TP21 & $\begin{array}{l}\text { MDAC } \\
\text { Thermopile }\end{array}$ & $492-1 / 2 \mathrm{R}$ & Interface $\mathrm{T}$ & & PDM \\
\hline TP22 & $\begin{array}{l}\text { MDAC } \\
\text { Thermopile }\end{array}$ & $491-1 / 2 R$ & Interface $\mathrm{T}$ & & PDM \\
\hline T P23 & $\begin{array}{l}\text { MDAC } \\
\text { Thermopile }\end{array}$ & $490-1 / 2 \mathrm{R}$ & Interface $T$ & & $\mathrm{PDM}$ \\
\hline $\mathrm{TP} 24$ & $\begin{array}{l}\text { MDAC } \\
\text { Thermopile }\end{array}$ & $489-1 / 2 \mathrm{R}$ & Interface $\mathrm{T}$ & & PDM \\
\hline TP25 & $\begin{array}{l}\text { MDAC } \\
\text { Thermopile }\end{array}$ & $488-1 / 2 \mathrm{R}$ & Interface $T$ & & PDM \\
\hline TP26 & $\begin{array}{l}\text { MDAC } \\
\text { Thermopile }\end{array}$ & $487-1 / 2 \mathrm{R}$ & Interface $T$ & & PDM \\
\hline TP27 & $\begin{array}{l}\text { MDAC } \\
\text { Thermopile }\end{array}$ & $486-1 / 2 \mathrm{R}$ & Interface $T$ & & PDM \\
\hline TP31 & $\begin{array}{l}\text { MDAC } \\
\text { Thermopile }\end{array}$ & $588-1 / 2 \mathrm{R}$ & Interface $T$ & & PDM \\
\hline TP32 & $\begin{array}{l}\text { MDAC } \\
\text { Thermopile }\end{array}$ & $587-1 / 2 \mathrm{R}$ & Interface $T$ & & PDM \\
\hline TP33 & $\begin{array}{l}\text { MDAC } \\
\text { Thermopile }\end{array}$ & $586-1 / 2 \mathrm{R}$ & Interface $T$ & & PDM \\
\hline TP34 & $\begin{array}{l}\text { MDAC } \\
\text { Thermopile }\end{array}$ & $585-1 / 2 \mathrm{R}$ & Interface $\mathrm{T}$ & & PDM \\
\hline TP35 & $\begin{array}{l}\text { MDAC } \\
\text { Thermopile }\end{array}$ & $584-1 / 2 \mathrm{R}$ & Interface $T$ & & PDM \\
\hline TP36 & $\begin{array}{l}\text { MDAC } \\
\text { Thermopile }\end{array}$ & $583-1 / 2 \mathrm{R}$ & Interface $T$ & & PDM \\
\hline
\end{tabular}


Table 1

INSTRUMENTATION DATA (Page 4 of 4)

\begin{tabular}{|c|c|c|c|c|c|}
\hline No. & $\mathrm{P} / \mathrm{N}$ & $\begin{array}{l}\text { Station } \\
\text { Location }\end{array}$ & $\begin{array}{c}\text { Function } \\
(\mathrm{T}=\mathrm{Temp})\end{array}$ & $\begin{array}{r}\text { Range } \\
{ }^{\circ} \mathrm{K}\left({ }^{\circ} \mathrm{R}\right)\end{array}$ & Data \\
\hline TP37 & $\begin{array}{l}\text { MDAC } \\
\text { Thermopile }\end{array}$ & $582-1 / 2 \mathrm{R}$ & Interface $\mathrm{T}$ & & PDM \\
\hline LLl & Ohmite Res & $383-1 / 2 R$ & Liquid Level & & $\mathrm{S} / \mathrm{C}$ \\
\hline LL2 & Ohmite Res & $384-1 / 2 \mathrm{R}$ & Liquid Level & & $\mathrm{S} / \mathrm{C}$ \\
\hline LL3 & Ohmite Res & $420-1 / 2 \mathrm{R}$ & Liquid Level & & $\mathrm{S} / \mathrm{C}$ \\
\hline LL4 & Ohmite Res & $456-1 / 2 \mathrm{R}$ & Liquid Level & & $\mathrm{S} / \mathrm{C}$ \\
\hline LL5 & Ohmite Res & $491-1 / 2 R$ & Liquid Level & & $\mathrm{S} / \mathrm{C}$ \\
\hline LL6 & Ohmite Res & $492-1 / 2 R$ & Liquid Level & & $\mathrm{S} / \mathrm{C}$ \\
\hline LL7 & Ohmite Res & $528-1 / 2 R$ & Liquid Level & & $\mathrm{S} / \mathrm{C}$ \\
\hline LL8 & Ohmite Res & $564-1 / 2 R$ & Liquid Level & & $\mathrm{S} / \mathrm{C}$ \\
\hline LL9 & Ohmite Res & $587-1 / 2 \mathrm{R}$ & Liquid Level & & $\mathrm{S} / \mathrm{C}$ \\
\hline LL10 & Ohmite Res & $588-1 / 2 R$ & Liquid Level & & $\mathrm{S} / \mathrm{C}$ \\
\hline TF1 & TS1 1080-1 & $\mathrm{F}_{2}$ Line & $\mathrm{GF}_{2} \mathrm{~T}$ & $222-305 \quad(400-550)$ & $\mathrm{S} / \mathrm{C}$ \\
\hline TI1 & CR-AL T/C & $\begin{array}{l}\text { Injector } \\
\text { l st Stage }\end{array}$ & Injector $\mathrm{T}$ & $\begin{array}{l}20-1,645 \\
(36-2,960)\end{array}$ & $\mathrm{S} / \mathrm{C}$ \\
\hline TI2 & $\mathrm{CR}-\mathrm{AL} \mathrm{T} / \mathrm{C}$ & $\begin{array}{l}\text { Injector } \\
\text { 2nd Stage }\end{array}$ & & $\begin{array}{l}20-1,645 \\
(36-2,960)\end{array}$ & $\mathrm{S} / \mathrm{C}$ \\
\hline TI3 & $\mathrm{CR}-\mathrm{AL} \mathrm{T} / \mathrm{C}$ & $\begin{array}{l}\text { Injector } \\
\text { 2nd Stage }\end{array}$ & & $\begin{array}{l}20-1,645 \\
(36-2,960)\end{array}$ & $\mathrm{S} / \mathrm{C}$ \\
\hline
\end{tabular}


$\left(0-345 \times 10^{3} \mathrm{~N} / \mathrm{m}^{2}[0-50 \mathrm{psia}]\right)$ transducer. All pressures were recorded on Leeds and Northrup Speedomax H (Model 1022) strip charts for continuous data evaluation during testing.

\section{MTI SYSTEM MODIFICATIONS}

The general MTI system design requirements for this program were the same as for the previous test program under Contract NAS3-13306:

A. Self-regulating.

B. Capable of controlled pressurization, pressure hold, and expulsion at varied $\mathrm{LH}_{2}$ outflow rates up to a maximum of $6.8 \mathrm{~kg} / \mathrm{sec}(15 \mathrm{lb} / \mathrm{sec})$.

C. Operable at any ullage volume.

D. Capable of a wide range of flow rates and operating pressures.

E. Able to pressurize the tank to within $6,895 \mathrm{~N} / \mathrm{m}^{2}$ (l psia) of the desired pressure.

F. Capable of safe operation without damaging the injector or tank, or freezing of fluorine in the injector, and causing minimum heat leakage into the tank when not in operation.

The basic MTI control and injection system used for the previous program was used for this one; however, due to the unique nature of the NAR injector, some system modifications were necessary. The new MTI control and injection system is shown schematically in Figure 16 and the reasons for the component selection are discussed below.

For steady $\mathrm{LH}_{2}$ outflow at constant tank pressure, the maximum MTI pressurization energy requirements occur at the end of the test when the tank is nearly empty because the heat transfer losses to the wall are highest. If the $\mathrm{GF}_{2}$ injection rate is sized to the maximum energy requirements, excessive $\mathrm{GF}_{2}$ inflow will occur at the beginning of $\mathrm{LH}_{2}$ outflow. To control the $\mathrm{GF}_{2}$ inflow, the flow rate must either 


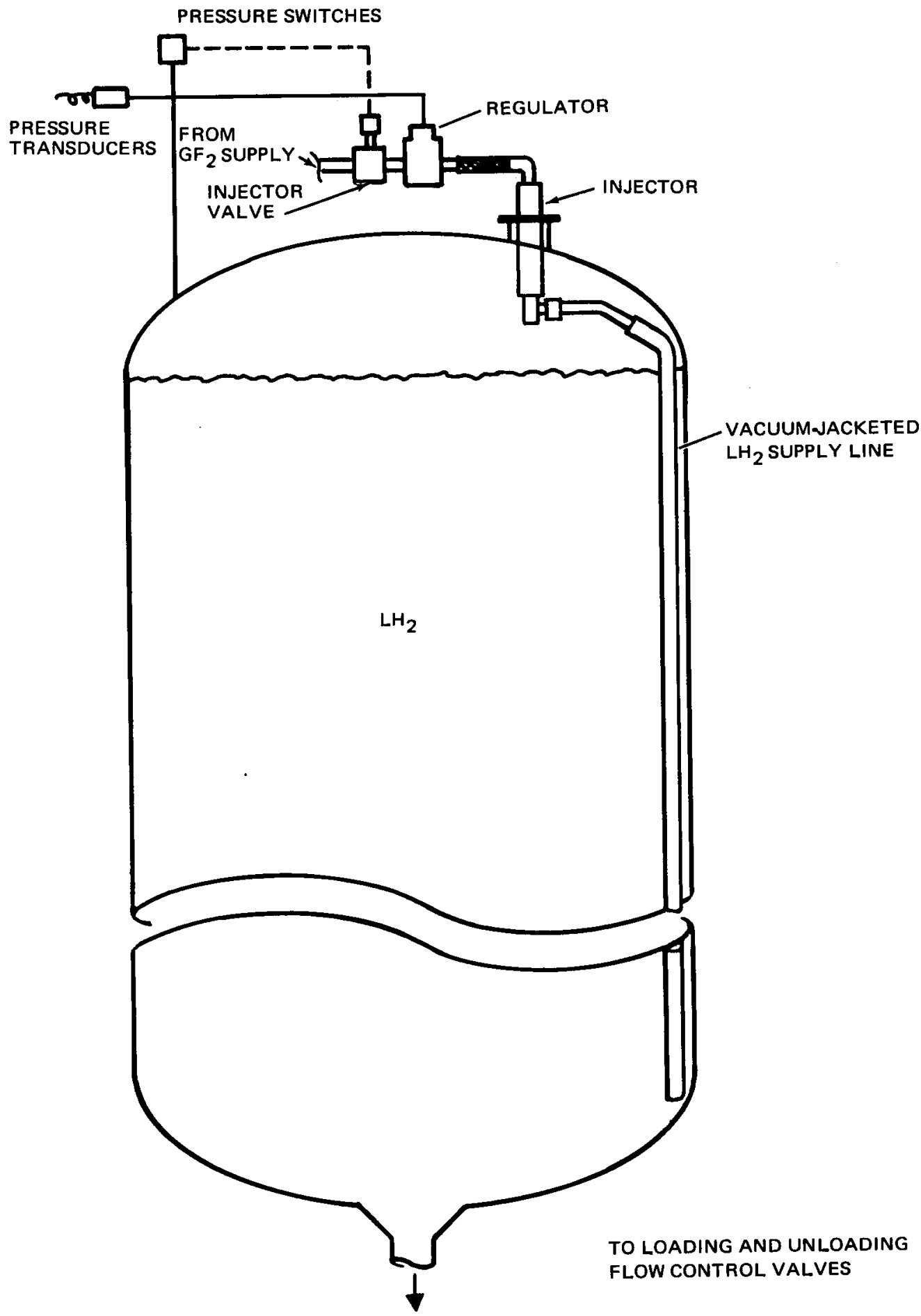

Figure 16. Test Tank Injector Installation 
be continuously varied, or the $\mathrm{GF}_{2}$ flow held constant and cycled on and off to provide the proper energy input. The latter solution, called a "bang bang" system, was used on the previous program and is suitable for this programas well, since the NAR injector is a constant-. low device. The control system is implemented by using pressure switches tosense tankpressure and openand close the injectorvalve to keep the tank pressurewithin a narrow band. The pressureswitches used were completely redundant individually plumbed mercury-type pressure switches, Mercoid type APH-41-153. The switches have a range of 10.3 to $31 \times 10^{4} \mathrm{~N} / \mathrm{m}^{2}$ (15 to $45 \mathrm{psia}$ ) and could be individually set to any pressure within this range with a maximum actuation band (relay energize-to-denergize) of $\pm 2.58 \times 10^{3} \mathrm{~N} / \mathrm{m}^{2}( \pm 0.375 \mathrm{psia})$. This switch had a maximum time delay of 15 milliseconds and was safe for operation in an $\mathrm{H}_{2}$ atmosphere because the contacts were sealed. The switch would not be suitable for flight vehicle use, however, because the mercury element must be level and is thus g-vector sensitive. Bellows-type switches suitable for flight use with the same fast response and narrow actuation band are available, but must be custom-made (especially for $\mathrm{H}_{2}$ service) and are very expensive. Their use was deemed to be not cost-effective for this program. The chosen switch was available off-the-shelf, inexpensive, and suitable for ground service within an $\mathrm{H}_{2}$ atmosphere without sacrifice of accuracy, response, or safety.

When the preset actuation pressure (tank pressure) is reached, the pressure switch relay terminates $G_{2}$ inflow by closing the injector valve. When $\mathrm{LH}_{2}$ outflow or heat transfer causes the tank pressure to drop to the lower limit of the actuation band, the pressure switch relay reopens the injector valve. 
The $\mathrm{GF}_{2}$ supply system used for the previous MTI tests utilized a simple $\mathrm{GF}_{2}$ storage cylinder blowdown mode, with $G F_{2}$ flow principally controlled across the injector valve. However, for the NAR injector tests, two critical flow-control devices exist downstream of the injector valve: The injector proper and the regulator, both of which operate at a near-critical pressure ratio. Because of this, the Fox injector valve, Part No. 610851, as configured and used on the NAS3-13306 tests, would not have been capable of flowing sufficient $\mathrm{GF}_{2}$ without a prohibitively large pressure drop. Therefore, the Fox valve flow orifice was increased to the maximum diameter possible (approximately $6.35 \times 10^{-3} \mathrm{~m}[0.25 \mathrm{in}$.]) without redesign of the actuator assembly. This minimized pressure drop across the injector valve. This modification allowed use of the same reliable injector valve successfully used on the two previous MTI programs under Contracts NAS3-13306 and NAS3-7963.

The Fox injector valve is liquid-and gaseous-fluorine compatible and has a copper-on-stainless-steel seat. The valve was actuated by $3,447 \times 10^{3} \mathrm{~N} / \mathrm{m}^{2}$ (500 psia) helium through two integral solenoids, one to actuate open and the other to actuate closed. The high-pressure helium actuation enabled extremely fast valve response (closed to full-open or vice versa in less than 10 milliseconds. Use of helium (rather than spring-loading) to actuate closed was required to provide the high seat loadings necessary to affect a leak-tight metal-to-metal seal. In the event of power failure, the valve would remain in its last position, which could be open. The valve, therefore, incorporated a pressurized override which was utilized by attaching a normally open valve (energized closed by the main power) to the override. In the event of power failure, the normally open valve would open, thus pressurizing the injector valve closed. 
The requirement for pressure regulation of the $G F_{2}$ supplied to the NAR injector was necessary to provide sufficient pressure differential in the injector second stage annulus to properly pump $\mathrm{LH}_{2}$. Nominally, the NAR injector $\mathrm{GF}_{2}$ inlet pressure should be about 2.25 times the $\mathrm{LH}_{2}$ inlet (tank) pressure. However, this $\mathrm{GF}_{2}$ pressure cannot be a fixed value (relative to the preset tank pressure), as shown by the following example: For a tank pressure of $30 \times 10^{4} \mathrm{~N} / \mathrm{m}^{2}(43 \mathrm{psia})$, the $\mathrm{GF}_{2}$ inlet pressure would be $67 \times 10^{4} \mathrm{~N} / \mathrm{m}^{2}(97 \mathrm{psia})$, and the second stage ejector static pressure would be 0.16 times that or $10.7 \times 10^{4} \mathrm{~N} / \mathrm{m}^{2}(15.5 \mathrm{psia})$. Assuming a 90 -percent ullage in the Thor test tank, the $\mathrm{LH}_{2}$ inlet pressure could start as low as 10.3 x $10^{4} \mathrm{~N} / \mathrm{m}^{2}$ (15.0 psia) (initial tank pressure at the start of prepressurization minus the hydrogen head). Thus, during prepressurization, the injector would pump no $\mathrm{LH}_{2}$ until the $\mathrm{LH}_{2}$ inlet pressure increased above $10.7 \times 10^{4} \mathrm{~N} / \mathrm{m}^{2}$ (15.5 psia) due to the tank pressure rise; even then, the injector would operate at high $\mathrm{O} / \mathrm{F}$ ratios and temperatures until the tank pressure approached the design tank pressure. For a 90-percent ullage, the prepressurization time could be as long as 60 seconds (Reference 2 ) and the injector, operating at high $\mathrm{O} / \mathrm{F}$ ratios, could be hot for several seconds during the prepressurization cycle. This situation would also be true for the injector demonstration test where the $\mathrm{LH}_{2}$ inlet pressure stays at about $10.1 \times 10^{4} \mathrm{~N} / \mathrm{m}^{2}$ (14.7 psia), and there would be no $\mathrm{LH}_{2}$ flow. It is clear, therefore, that the $\mathrm{GF}_{2}$ regulator must be designed to provide a constant ratio of 2. 25 times $\mathrm{LH}_{2}$ inlet (tank) pressures from 10.1 to $30 \times 10^{4} \mathrm{~N} / \mathrm{m}^{2}$ (14.7 to 43 psia). Further, the regulator must be capable of flowing $0.0317 \mathrm{~kg} / \mathrm{sec}(0.07 \mathrm{lb} / \mathrm{sec})$ of $294^{\circ} \mathrm{K}\left(530^{\circ} \mathrm{R}\right) \mathrm{GF}_{2}$ at $62 \times 10^{4} \mathrm{~N} / \mathrm{m}^{2}$ (90 psia) downstream and approximately $138 \times 10^{4} \mathrm{~N} / \mathrm{m}^{2}$ (200 psia) upstream ( $\mathrm{GF}_{2}$ pressure downstream of the injector valve). An offthe-shelf regulator to meet these requirements did not exist; therefore, a special regulator was designed jointly by MDAC and Wintec Corp. A cutaway of this regulator (MDAC P/N 1 T42072; Wintec 
$\mathrm{P} / \mathrm{N}$ 1346-5700) is shown in Figure 17. The regulator has many unique features. A differential-area piston in the ratio of 2.25:1 is used to regulate the $G_{2}$ pressure to a value of 2.25 times the tank pressure. The dome of the regulator is pressurized with hydrogen from the tank ullage (see Figure 16). To positively separate the $\mathrm{GH}_{2}$ in the dome from the $\mathrm{GF}_{2}$ in the regulator, a double-sealed $\mathrm{GN}_{2}-$ "purged" (actually dead-headed) port is provided. $\mathrm{GN}_{2}$ was supplied to the port at $138 \times 10^{4} \mathrm{~N} / \mathrm{m}^{2}(200 \mathrm{psia})$ so that the pressure in the sealed cavity was always higher than both the dome $\mathrm{GH}_{2}$ pressure and the regulated $G_{2}$ pressure (even during the starting surge). In addition, an overboard vent was provided under the piston step to relieve any leakage that could occur. Because the regulator had to deliver an absolute pressure ratio of $2: 25: 1$, the atmospheric pressure force under the piston was counteracted with a trim spring. This spring also compensated for the small residual force from the balanced poppet (which was used to minimize the effects of varying upstream pressure). The moving seals in the regulator were of the omni-seal type. In order to minimize the frictional force of the seals, which contribute to hysteresis in the regulation, special close-tolerance seals were procured, and the piston was split to allow seal in stallation without stretching the seals. The frictional force of the seals contributes to more regulation error at low dome pressures (and low forces) than at high pressures. The trim spring was used to set the regulator to give the best regulated pressure ratio at each basic steady-state dome pressure. The regulator had a 316 stainless steel poppet and a brass seat. The internal leakage was less than $3.17 \times 10^{-7} \mathrm{~m}^{3} / \mathrm{sec}$ (19 $\mathrm{sccm}$ ) but the regulator was situated downstream from the injector valve (see Figure 16) so that with the valve off, the regulator will be wide open, thus allowing greater tolerances on internal leakage across the metal-to-metal regulator seat. The performance of the regulator, reported on in the Experimental Results section, was excellent. 


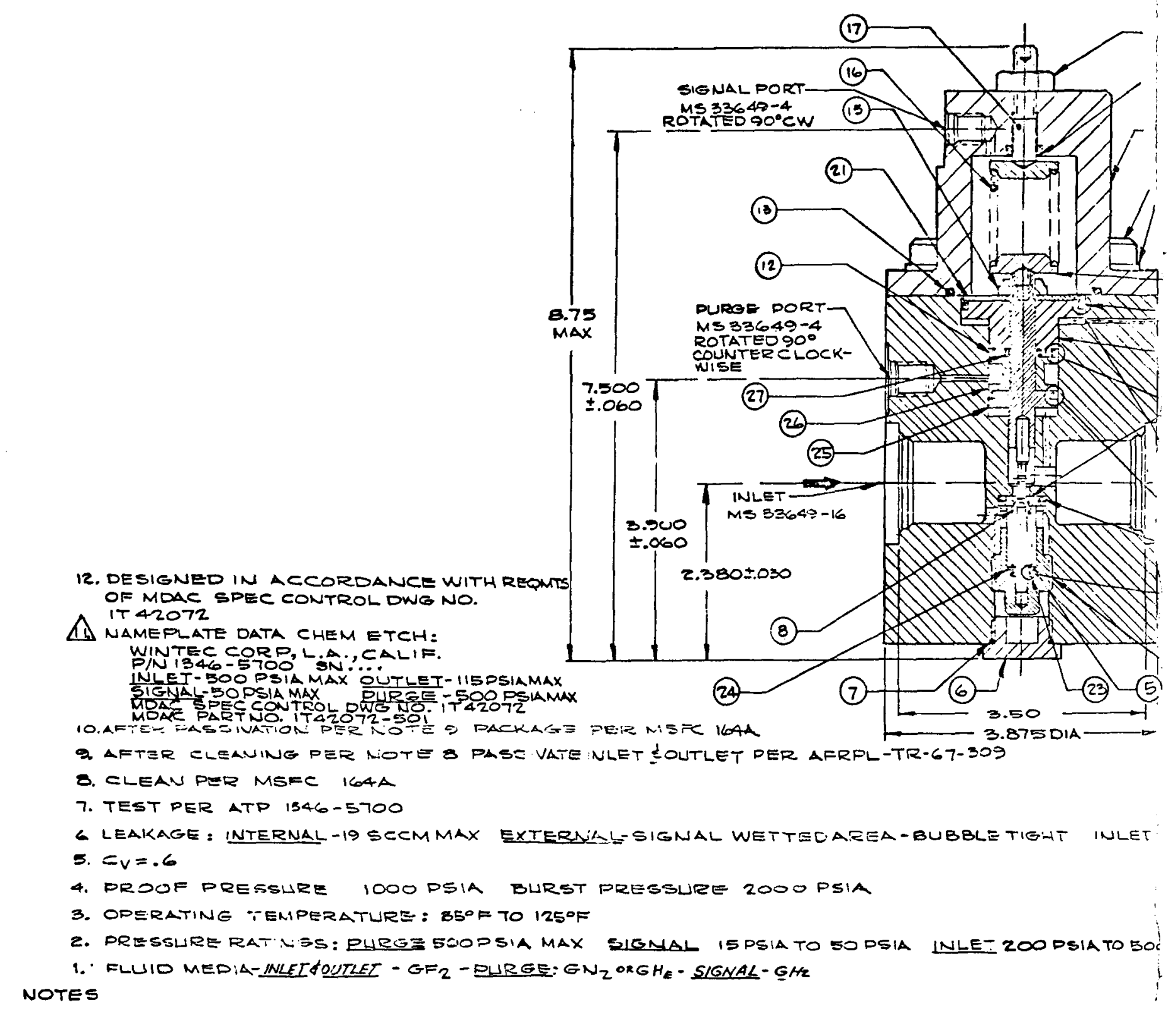

Figure 17. Pressure Regulator Drawing 
;)

(19)

(2)

-(1)

-(i)

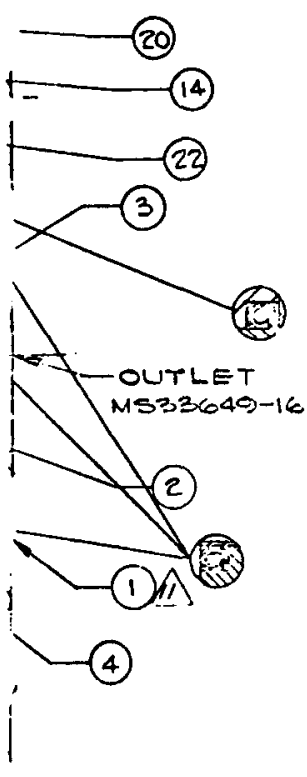

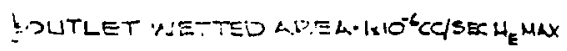

DPSIA OUTLET $2.25 \times$ SIGNALE $10 \%$

\begin{tabular}{|c|c|c|c|c|c|}
\hline 27 & 1 & Q-RING & $0208-2012$ & TEFLON & \\
\hline 26 & 1 & SPACER & $1346-3713$ & CRES & \\
\hline 25) & 1 & GUIOE & $1346-5714$ & CRES & \\
\hline 24 & 1 & WASHER & $1346-5713$ & CRES & \\
\hline 23 & 1 & seAl & $1346-5716-1$ & TEFLONKERES & \\
\hline 22 & 1 & PISTON & $1346-5712$ & CRES & \\
\hline 21 & 1 & WASHER,RET. & $1346-5711$ & CRES & \\
\hline 20 & 2 & BLTTOMSPRINS & $1346-9710$ & CRES & \\
\hline 19 & 1 & O-RINS & $0208-2111$ & TEELON & \\
\hline 18 & 1 & NUT & $\dot{A} N 316-5 R$ & & \\
\hline 17 & 1 & SCREW,AD & $13410-1309$ & ERES & \\
\hline 16 & 1 & SPRING & 122913 & $\angle R=S$ 17-7DH & \\
\hline 15 & 1 & NUT & NAS1022C6 & $c 2 \equiv s$ & \\
\hline 14 & 1 & SEAL & $1346-5716-3$ & TEFLNACRES & \\
\hline 13 & 1 & D-RINS & $0209-2137$ & TEFLON & \\
\hline 12 & 2 & SEAL & $1346-5716-2$ & TEFLONSCRES & \\
\hline 11 & 6 & WASHER & 99020 & STLCADPL & \\
\hline 10 & 6 & SCREW, CAPSOSHD & $\frac{1}{2}-352 \times 1-34 \times 756$ & JTLCADPL & \\
\hline 9 & 1 & DOME & $1346-5707$ & CRES 316 & \\
\hline 8 & 1 & POPPET & $1346-5705$ & CRES 31.6 & \\
\hline 7 & 1 & O-RINSE & $0203-3010$ & TEELON & \\
\hline 6 & 1 & PLIJS & $115150-2$ & CRES 316 & \\
\hline 5 & 1 & SPRINE & 112727 & CRES 17-7PH & \\
\hline 4 & 1 & RET ANER, SEAT & $1346-5703$ & CEES 316 & \\
\hline 5 & 1 & SEAT & $1346-5702$ & BPASO & \\
\hline 2 & 1 & O-RING & $0208-2015$ & TEFLON & \\
\hline 1 & 1 & BODY & $1346-5701$ & CRES 316 & \\
\hline $\begin{array}{l}\text { TEm } \\
\text { No. } \\
\end{array}$ & & neme & 10. & MATERIAL & \\
\hline
\end{tabular}

LIST JF MATERIAL 
During the NAS3-13328 injector acceptance tests (see Reference 3), NAR apparently had considerable difficulty in providing $\mathrm{LH}_{2}$ to the injector, as indicated by Figure 7. Points 001, 003, and 004 lie close to the theoretical line, but point 002 is at a much higher $\mathrm{O} / \mathrm{F}$ ratio (and much hotter) because of vaporization of $\mathrm{LH}_{2}$ in the feed line to the injector and subsequent restriction of hydrogen flow. It was feared the same problem might occur in the tank tests with large ullages. For some tests, the $\mathrm{LH}_{2}$ feed line from the tank bottom sump to the injector (Figure 16) will pass through a relatively warm ullage, possibly as warm as $333^{\circ} \mathrm{K}\left(600^{\circ} \mathrm{R}\right)$ for a 90 -percent ullage prepressurization. The heat flux from the ullage to the $\mathrm{LH}_{2}$ feed line was calculated to vaporize sufficient $\mathrm{LH}_{2}$ to reduce the hydrogen flow rate by a factor of four. The injector feed line must therefore be insulated from the ullage to ensure that $\mathrm{LH}_{2}$ reaches the injector. The insulation must be compatible with $\mathrm{LH}_{2}$, hydrogen fluoride (HF), and high temperatures. The least complex insulation technique was to use a vacuum-jacketed line. Thus a $1.27 \times 10^{-2}-\mathrm{m}(1 / 2$-in. $)$ diameter vacuum-jacketed line (vendor-pumped and permanently sealed) was installed in the test tank (Figure 16). The line weighed about $6.8 \mathrm{~kg}$ (15 1b) but restricted the $\mathrm{LH}_{2}$ flow degradation to a few percent.

The MTI control system used to actuate all valves, etc., was essentially the same as used during the NAS3-13306 tests, and is described in detail in Reference 2. The only major modification to the control system was the elimination of the infrared (IR) ignition detector. This was done for two reasons: (1) It was deemed no longer necessary for system safety. In 11 previous ullage injection tests under Contract NAS3-7963, and 17 previous ullage injection tests under Contract NAS3-13306, there was never a case of nonignition. Further, with the NAR injector and its "preburner" first stage, there is even less chance of nonignition (NAR obtained reliable ignition in all 12 firing 
tests under NAS3-13328), (2) The installation of the NAR injector in the available Thor tank ports precluded being able to look directly at the injector with the IR detector. In previous "offset injector" tests under Contract NAS3-13306, the IR detector was unable to look directly at the injector with the result that there were three test shutdowns due to spurious IR detector nonignition signals (in fact, two tests were run without the IR detector in the circuit). To avoid this problem in this program, the IR detector was eliminated, and ignition was reliably sensed by the rapid tank pressure rise during firing.

The complete assembled $\mathrm{GF}_{2}$ injection loop, shown schematically in Figure 16, is a compact installation on top of the Thor test tank, as shown in Figure 18. The flex line between the regulator and injector allowed movement of the injector due to thermal expansion

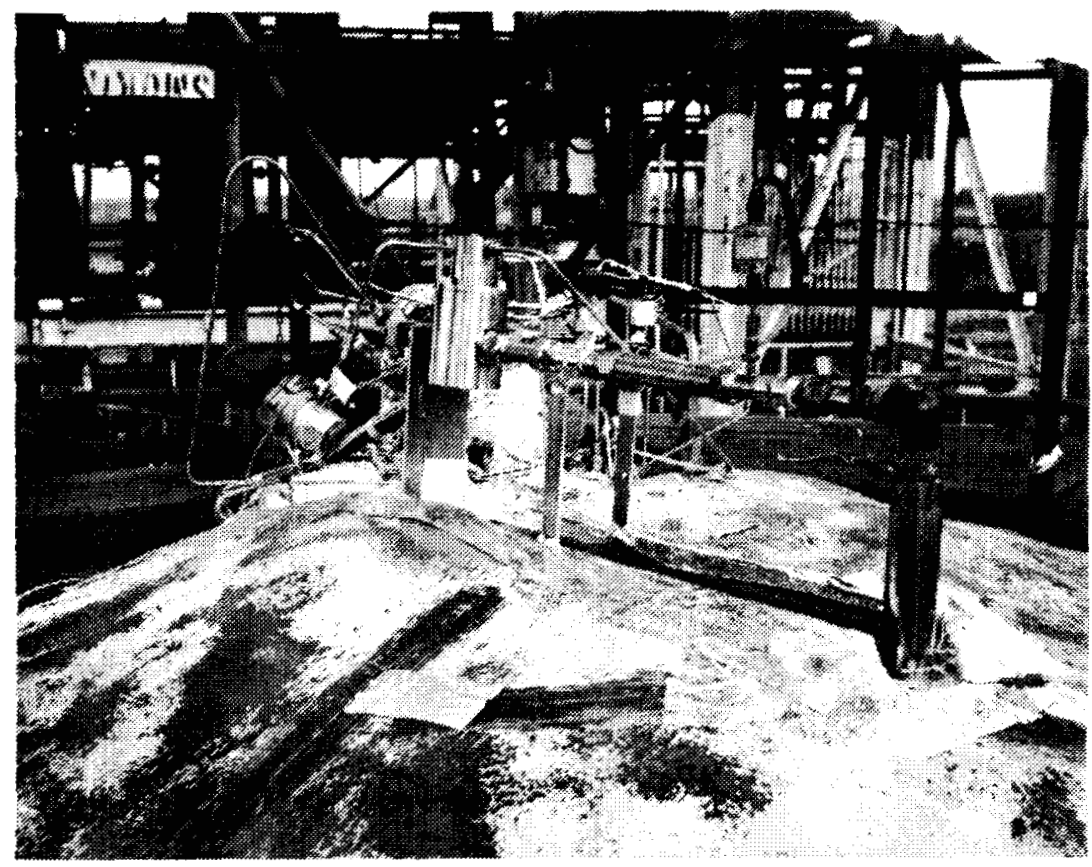

Figure 18. Injection Assembly Installation on Test Tank 
when operating and allowed installation flexibility. The entire assembly was passivated with $G F_{2}$ prior to testing and was also used in essentially the same configuration for the injector demonstration tests discussed below. 


\section{EXPERIMENTAL RESULTS}

\section{INJECTOR DEMONSTRATION TEST}

Prior to installation of the NAR injector in the Thor test tank, the injector was hot-fired in a cold $\mathrm{GH}_{2}$ atmosphere with $\mathrm{GF}_{2}$ flow on-off cycle rates simulating the injector cycling anticipated in the Thor tank tests.

The purpose of this test was twofold:

1. To verify the structural adequacy of the injector, and reveal any injector burning problems which could occur.

2. To verify the proper operation of the MTI control system and $G F_{2}$ supply system.

The apparatus used for this test was essentially the same used for the previous injector demonstration tests under Contract NAS3-13306. The apparatus, shown in Figure 19, consists of a horizontally mounted stainless steel pipe $0.3 \mathrm{~m}$ (12 in.) in diameter by $3 \mathrm{~m}$ (10 ft) long. Some modifications to the test apparatus were made to adapt it to the NAR injector, which was configured with the first stage outside the pipe at ambient temperature, and the second stage inside the pipe. The injector was mounted axially along the pipe centerline through a blind flange at one end of the pipe. The liquid hydrogen flow was introduced along the bottom of the pipe, where it partially boiled, providing a cold $\mathrm{GH}_{2}$ atmosphere in the pipe. The pipe apparatus was modified by the addition of a series of baffles and a foam-insulated $\mathrm{LH}_{2}$ sump, as shown in Figure 19. These decelerated the $\mathrm{LH}_{2}$ flow and provided a sump from which saturated $\mathrm{LH}_{2}$ at $10.1 \times 10^{4} \mathrm{~N} / \mathrm{m}^{2}$ (14.7 psia) could be drawn to the injector. A $7.6 \times 10^{-2}-\mathrm{m}(3-\mathrm{in}$. 
diameter pyrex window was installed near the injector tip, through which high-speed motion pictures were taken at the rate of 250 frames per second with a Mitchell Monitor Model 500 camera. This exposure rate allowed 180 seconds of film time using a $366-\mathrm{m}(1,200-\mathrm{ft})$ magazine, and it had been hoped that direct comparison could be made with the motion pictures taken (also at a 250 frames-per-second rate) of the previous MTI injectors. This was not possible, however, because the view was generally obscured by clouds of $\mathrm{H}_{2}$ vapor and $\mathrm{LH}_{2}$ splashing on the camera window.

The test pipe was installed at the Alpha Complex-Site 3, STC (as shown in Figure 20). GF 2 from the MTI control pallet was plumbed to the site, and $\mathrm{LH}_{2}$ was available from the facility supply. During installation of the injector in the test pipe, the $\mathrm{GF}_{2}$ flow tube in the injector was accidentally torqued. To verify that no damage had occurred, the injector was flow-proofed with GHe at $10^{6} \mathrm{~N} / \mathrm{m}^{2}(145$ psia), and externally leak-checked with GHe at $7.1 \times 10^{5} \mathrm{~N} / \mathrm{m}^{2}(103$ psia). No external leakage was detected, and subsequent measurements indicated that although the injector was twisted slightly, it had not been stretched or otherwise damaged by the incident.

The firing test was conducted according to MDAC Countdown ManualSite 3 (MDAC Drawing 1 T17019) requirements. The plan was to fire the injector continuously for 60 seconds, then cycle the injector for 60 seconds at 0.1 second $O N, 0.9$ second OFF, and finally cycle the injector for 60 seconds at 0.9 second ON, 0.1 second OFF. During the first 60 seconds of continuous firing, the injector behaved normally, with the first stage temperature stabilizing at $320^{\circ} \mathrm{K}\left(570^{\circ} \mathrm{R}\right)$ and the second stage temperature stabilizing at $935^{\circ} \mathrm{K}\left(1,680^{\circ} \mathrm{R}\right)$. It was noted that the regulated $G F_{2}$ pressure to the injector overshot to $3.45 \times 10^{5}$ $\mathrm{N} / \mathrm{m}^{2}$ (50 psia) 0.5 second after the injector valve opened, then slowly 


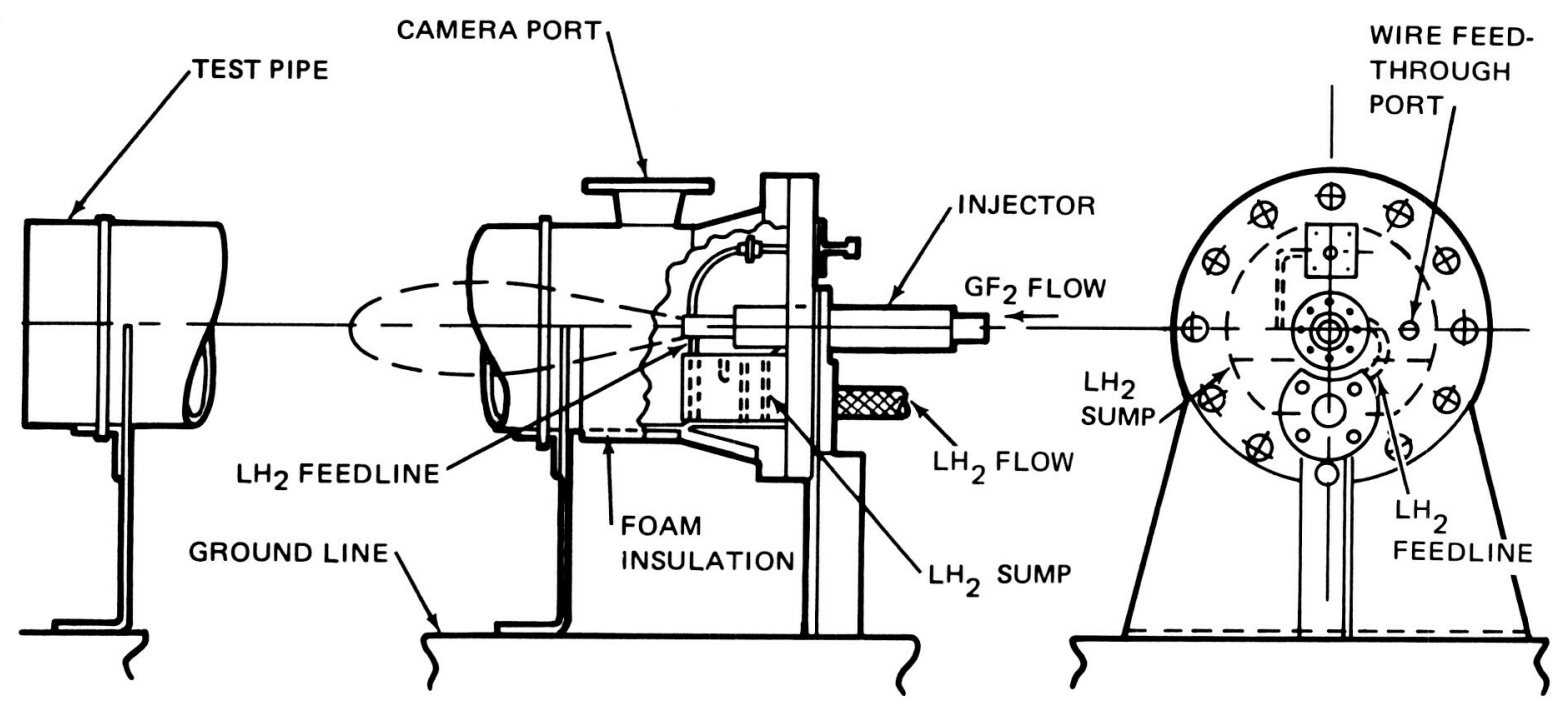

Figure 19. Injector Demonstration Test Apparatus

CR25

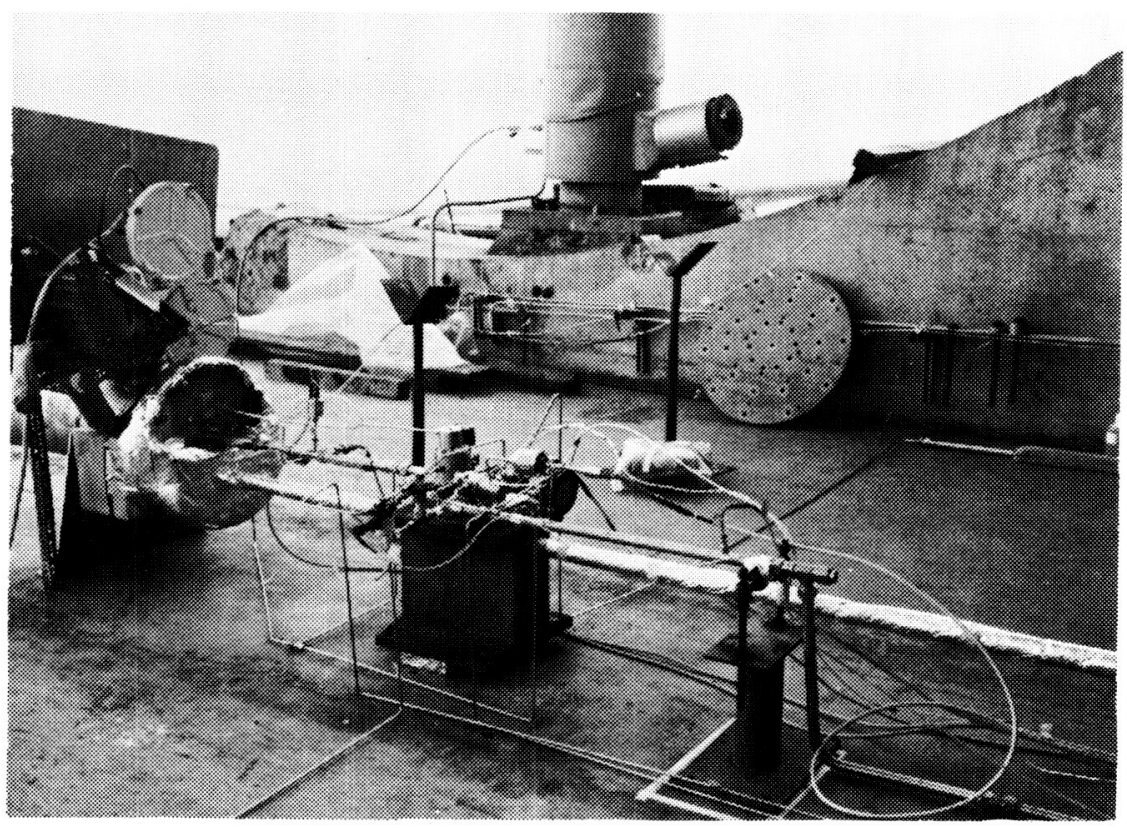

Figure 20. Installation of Injector Test Apparatus 
dropped to $2.85 \times 10^{5} \mathrm{~N} / \mathrm{m}^{2}(41.3 \mathrm{psia})$ at a time of 64 seconds (the correct regulated pressure should have been $2.35 \times 10^{5} \mathrm{~N} / \mathrm{m}^{2}$ [34 psia]).

During the short ON cycle (0.1 second ON, 0.9 second $O F F)$, the first stage temperature increased to $350^{\circ} \mathrm{K}\left(625^{\circ} \mathrm{R}\right)$ and the second stage temperature dropped to $775^{\circ} \mathrm{K}\left(1,394^{\circ} \mathrm{R}\right)$. The regulated $\mathrm{GF}_{2}$ pressure cycled between $2.73 \times 10^{5} \mathrm{~N} / \mathrm{m}^{2}(30.6 \mathrm{psia})$ and $1.03 \times 10^{5}$ $\mathrm{N} / \mathrm{m}^{2}(15 \mathrm{psia})$. It appeared that the injector valve was open too short a time $\left(0.1\right.$ second) to allow the pressure to reach the $3.45 \times 10^{5}$ $\mathrm{N} / \mathrm{m}^{2}$ (50 psia) overshoot; consequently, the injector temperature decreased to $775^{\circ} \mathrm{K}\left(1,394^{\circ} \mathrm{R}\right)$ because of the relatively long OFF time and the cooling effect of the $\mathrm{H}_{2}$ in the test apparatus. However, during the long ON cycle ( 0.9 second $O N, 0.1$ second OFF), the regulator again overshot to $3.52 \times 10^{5} \mathrm{~N} / \mathrm{m}^{2}(51 \mathrm{psia})$ and oscillated between $3.52 \times 10^{5} \mathrm{~N} / \mathrm{m}^{2}(51 \mathrm{psia})$ and $2.07 \times 10^{5} \mathrm{~N} / \mathrm{m}^{2}(30 \mathrm{psia})$. The first stage temperature increased slowly to $514^{\circ} \mathrm{K}\left(924^{\circ} \mathrm{R}\right)$, but the second stage temperature immediately went off scale, indicating temperatures in excess of $1,650^{\circ} \mathrm{K}\left(2,960^{\circ} \mathrm{R}\right)$. This occurred so rapidly that it was thought the thermocouple had failed, and the test was allowed to continue, although it should have been terminated at this time. Following the test, inspection of the injector revealed that the nozzle diffuser, downstream of the second stage throat, had been damaged by overheating. Figure 21 shows the injector following the test. The $\mathrm{LH}_{2}$ sump and feed line are shown. The temperature in the $\mathrm{LH}_{2}$ feed line stayed at $21^{\circ} \mathrm{K} \cdot\left(37^{\circ} \mathrm{R}\right)$ throughout the test, although this may have been due to the cold $\mathrm{GH}_{2}$ atmosphere in the test pipe.

Apparently the abnormally high regulated $G_{2}$ pressure of $3.52 \times 10^{5}$ $\mathrm{N} / \mathrm{m}^{2}$ (5l psia) had reduced the $\mathrm{LH}_{2}$ pumping (aspiration) pressure difference, leading to reduced $\mathrm{LH}_{2}$ flow, higher injector $\mathrm{O} / \mathrm{F}$ ratio, and excessive temperatures. Injector failure probably did not occur during the initial overshoot to $3.45 \times 10^{5} \mathrm{~N} / \mathrm{m}^{2}(50 \mathrm{psia})$ during the 
60 -second continuous run because the injector was cold, and its thermal capacity allowed the injector to survive until the regulated $G F_{2}$ pressure dropped to a lower value.

The injector damage is shown in Figure 22. The view is in the direction of flow and shows the $\mathrm{LH}_{2}$ pumping annulus (the $\mathrm{LH}_{2}$ inlet port is top center). Detailed examination of the injector revealed that the damage was fortunately confined to the nozzle diffuser. The delicate expansion region of the second stage throat, although covered with molten metal, was essentially undamaged and was refurbished without replacement. The damaged diffuser was cut off the injector and a new nozzle diffuser was fabricated and welded to the injector, together with an additional thermocouple on the second stage.

It should be noted that the injector pumping ability is very sensitive to second-stage temperature. This is because higher temperatures in the $\mathrm{LH}_{2}$ pumping region tend to vaporize some of the $\mathrm{LH}_{2}$ in contact with the pumping annulus, which reduces the $\mathrm{LH}_{2}$ pumping effectiveness, leading to less $\mathrm{LH}_{2}$ flow, higher $\mathrm{O} / \mathrm{F}$ ratios and temperatures, and so forth. This is discussed in detail in the section, Analysis and Comparison of Injectors.

\section{PRESSURIZATION TESTS}

The regulator overshoot and subsequent injector failure during the firing test indicated the need for a number of operational changes; these were implemented in the tank pressurization tests. During the injector sequence checks of the pressure switches, the regulator was adjusted under flow to give the correct regulated pressure during overshoot under dynamic (cycling) conditions. In addition, the regulated pressure was viewed as a redline (shutdown) parameter in which, if the regulated pressure were to exceed 120 percent of the correct value (based on tank pressure), the $G_{2}$ flow would be terminated. The firing 


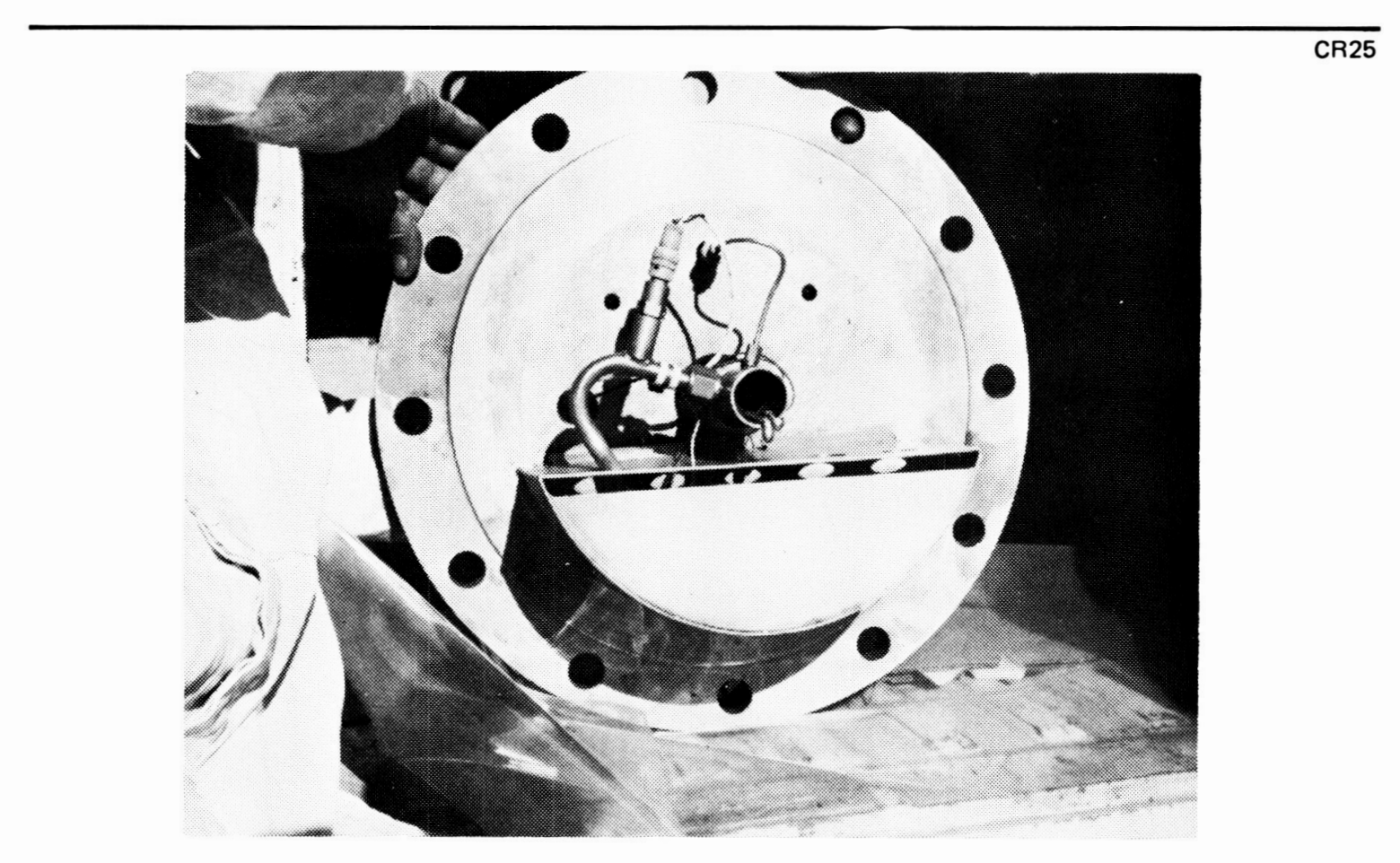

Figure 21. Injector Installation Following Firing Test

CR25

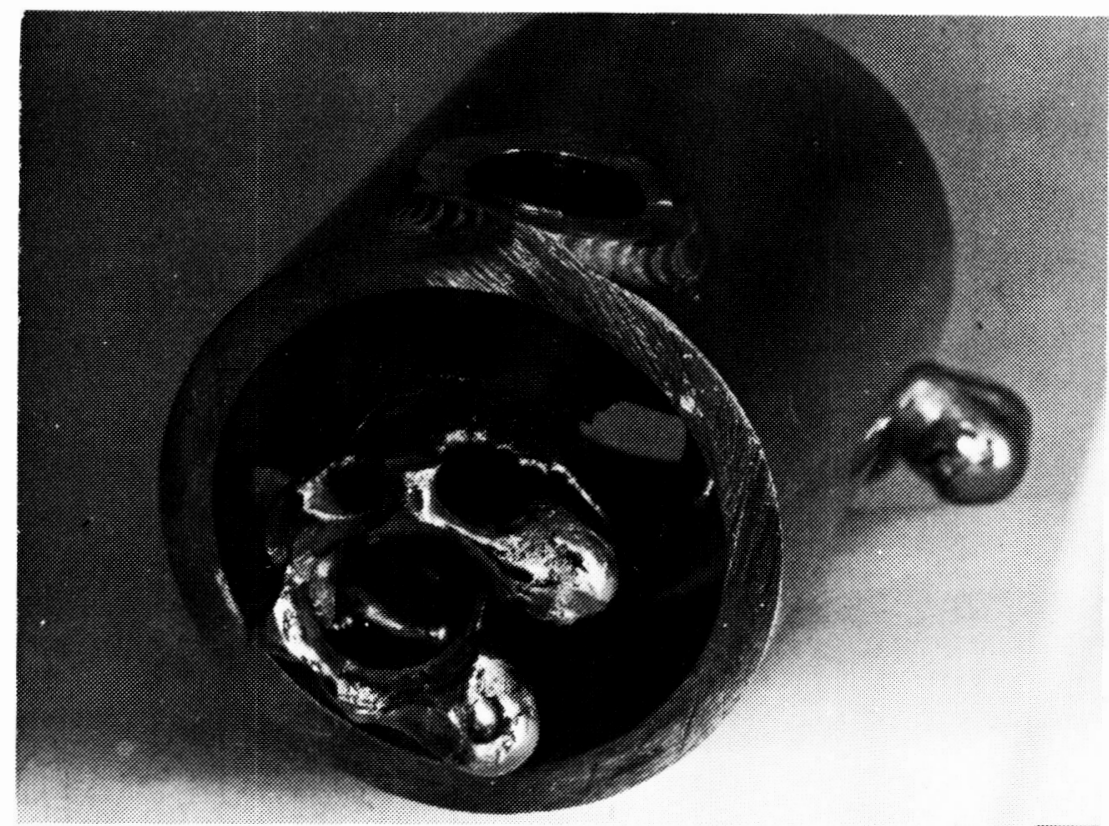

Figure 22. Injector Damage From Firing Test 
test data indicated that the second stage temperature stabilized at a value about $279^{\circ} \mathrm{K}\left(500^{\circ} \mathrm{R}\right)$ less than the theoretical combustion temperature at the presumed $\mathrm{O} / \mathrm{F}$ ratios which occurred; therefore, for the nominal $O / F$ ratio of $1.8: 1$ (maximum at a $G F_{2}$ pressure of $6.9 \times 10^{5} \mathrm{~N} / \mathrm{m}^{2}$ [100 psia]), the second stage temperature was redlined at $1,300^{\circ} \mathrm{K}\left(2,350^{\circ} \mathrm{R}\right)$. It was for redline reasons that a redundant thermocouple was added to the second stage. Further, as was done during the NAS3-13306 tests, the tank ullage pressure was redlined at $3.45 \times 10^{5} \mathrm{~N} / \mathrm{m}^{2}$ (50 psia), the ullage gas temperature at $555^{\circ} \mathrm{K}\left(1,000^{\circ} \mathrm{R}\right)$, and the tank wall temperature at $500^{\circ} \mathrm{K}\left(900^{\circ} \mathrm{R}\right)$.

The pressurization test sequence was also altered, so that the 5 -percent ullage tests were scheduled first and the 90 -percent tests, potentially more prone to injector failure from $\mathrm{LH}_{2}$ starvation, were scheduled last. The revised test sequence is presented in Table 2. The

Table 2

PRESSURIZATION TEST SEQUENCE

\begin{tabular}{|c|c|c|c|c|c|c|c|}
\hline Test & $\begin{array}{c}\text { Similar } \\
\text { NAS3-13306 } \\
\text { Test }\end{array}$ & $\begin{array}{c}\text { Tank Pr } \\
\left(10^{4}\right. \\
\left.\mathrm{N} / \mathrm{m}^{2}\right)\end{array}$ & $\begin{array}{l}\text { ssure } \\
\text { (psia) }\end{array}$ & $\begin{array}{l}\mathrm{LH}_{2} \\
\text { flow } \\
(\mathrm{kg} / \\
\text { sec) }\end{array}$ & $\begin{array}{l}\text { Out- } \\
\text { Rate } \\
(1 \mathrm{~b} / \\
\text { sec) }\end{array}$ & Ullage $(\%)$ & Hold \\
\hline 1 & 5 & 30 & 43 & 6.8 & 15 & 5 to 50 & None \\
\hline 2 & 6 & 30 & 43 & 6.8 & 15 & $\begin{array}{l}50 \text { (wa } \mathrm{rm} \text { ) to } \\
\text { empty }\end{array}$ & None \\
\hline 3 & 2 & 30 & 43 & 6.8 & 15 & 50 to empty & $60 \mathrm{sec}$ \\
\hline 4 & 4 & 30 & 43 & 6.8 & 15 & 5 to empty & None \\
\hline 5 & 7 & 17 & 25 & 2.3 & 5 & 5 to empty & $60 \mathrm{sec}$ \\
\hline 6 & 14 & 17 & 25 & 2.3 & 5 & 50 to empty & None \\
\hline 7 & 11 & 17 & 25 & 2.3 & 5 & 90 to empty & $60 \mathrm{sec}$ \\
\hline
\end{tabular}


straight-pipe tests of Contract NAS3-13306, which were conducted under similar operating conditions, are shown (also see Reference 2). The test conditions were made as similar as possible in order to more directly compare the performance of the straight-pipe and NAR injectors.

All tests were conducted according to MDAC Countdown Manual-Site 4 (MDAC Drawing 1 T17020) requirements. Prior to the tank pressurization tests, the $G_{2}$ system was passivated with $G_{2}$ at $69 \times 10^{4} \mathrm{~N} / \mathrm{m}^{2}$ (100 psia) and all GF 2 control components were exercised. Injection sequence checks were made to verify proper operation of the injection loop and pressure switches, and to verify that the GF 2 regulator delivered the correct pressure (approximately $67 \times 10^{4} \mathrm{~N} / \mathrm{m}^{2}$ [97 psia] at $30 \times 10^{4} \mathrm{~N} / \mathrm{m}^{2}$ [43 psia] in the dome or tank). The tank was loaded with $\mathrm{LH}_{2}$ and checked for leakage. All $\mathrm{LH}_{2}$ flow control valves were exercised and all instrumentation was checked for proper functioning.

In the first test attempt, the prepressurization occurred normally, but when initiation of $\mathrm{LH}_{2}$ outflow was attempted, the main $\mathrm{LH}_{2}$ flow control valve failed to open. Pressurization was terminated and the tank was vented. The flow control valve then opened normally and was left open. The $\mathrm{LH}_{2}$ outflow was henceforth initiated by opening the downstream $\mathrm{LH}_{2}$ rapid-unloading valve, although the outflow rate was controlled by modulating the main flow control valve.

Unfortunately, on the initial aborted pressurization test, the sensing line from the injector second stage static pressure tap to the transducer was burned off. Examination of the line indicated that the probable cause was that the initial surge of $G F_{2}$ through the injector pushed a flame front up the $\mathrm{GH}_{2}$-filled sensing line. The static pressure 
transducer henceforth actually indicated tank pressure, but this was not detected during the test series because it had been anticipated that the static pressure would probably be close to tank pressure (as was the case in the injector firing test).

The overall MTI test results are shown in Table 3. The times shown are the times following initial tank pressure rise until the pressure switch actuated, then the time at which outflow began, and then the time at which a sensor at a particular level indicated the exact ullage volume. The tank pressures shown in parentheses are not necessarily the exact pressures at that time, but indicate the low point of the initial pressure band (the most extreme). The $\mathrm{LH}_{2}$ outflow rate is the average between the time given and the previous time (e.g., for Test 1 , between $t=4$ seconds and 51 seconds, the average $\mathrm{LH}_{2}$ outflow rate was $6.13 \mathrm{~kg} /$ $\sec [13.5 \mathrm{lb} / \mathrm{sec}])$. The cumulative $G_{2}$ consumption is shown for each time, as are the maximum ullage and wall temperatures.

The MTI control system performed in a nominal manner, exactly as it had in the NAS3-13306 tests. This was because the response of the control system is strongly dependent on the pressure switch response, which did not change. Figure 23 shows the tank pressure history for Test 4 (5-percent initial ullage) during prepressurization and outflow, together with the regulated $G_{2}$ pressure history. Despite the very rapid prepressurization $(-4$ seconds), the control system maintains a tank pressure band of about $2 \times 10^{4} \mathrm{~N} / \mathrm{m}^{2}(3 \mathrm{psia})$ which soon narrows to less than $1.4 \times 10^{4} \mathrm{~N} / \mathrm{m}^{2}$ (2 psia). Note the abrupt change in the slope of the tank pressure decay from hold to outflow. The regulated $\mathrm{GF}_{2}$ pressure has a characteristic response caused by initial overshoot with the regulator wide open when the injector valve opens. This is followed by a period of roughly constant pressure until the tank pressure increases sufficiently to overcome the regulator seal friction 


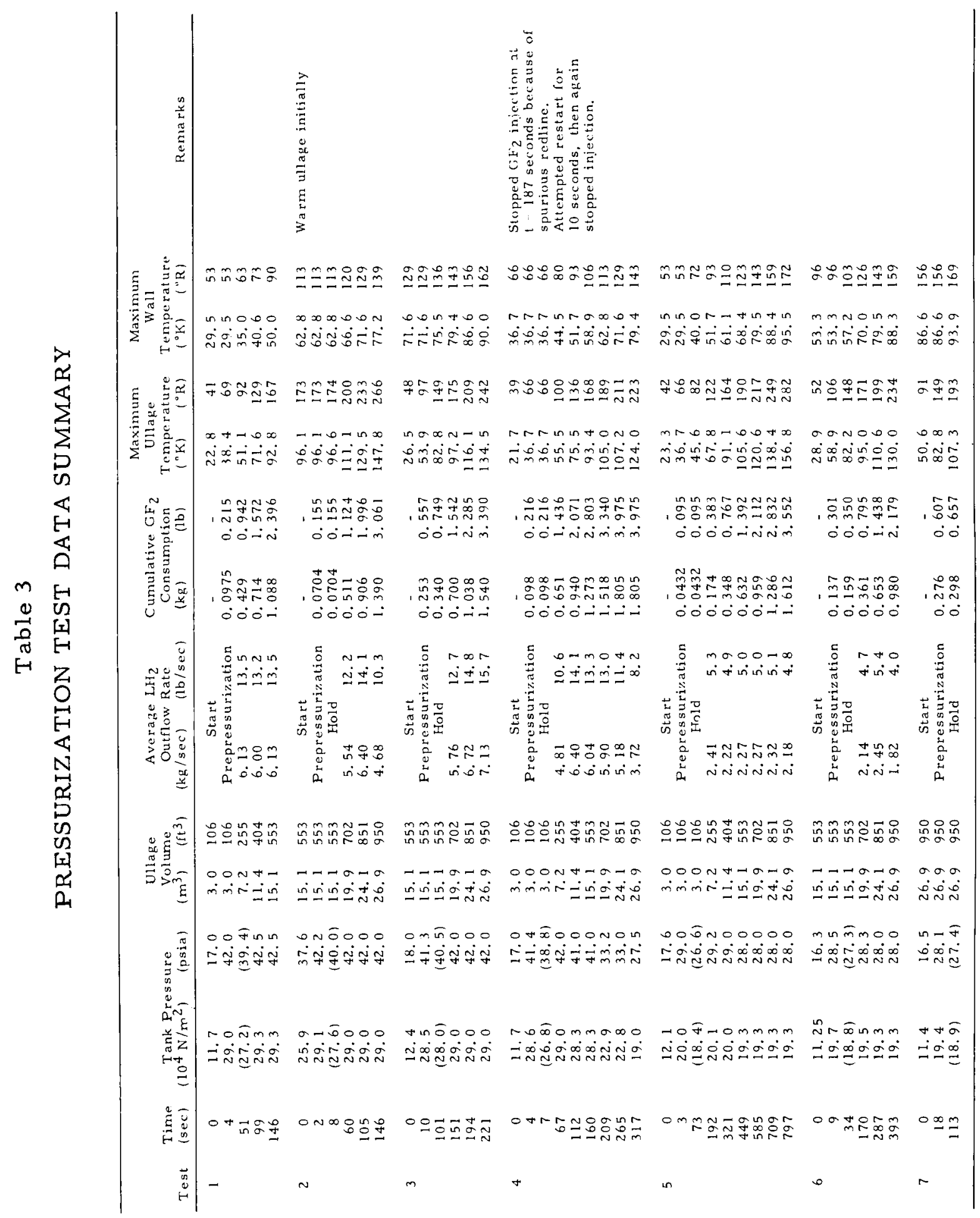




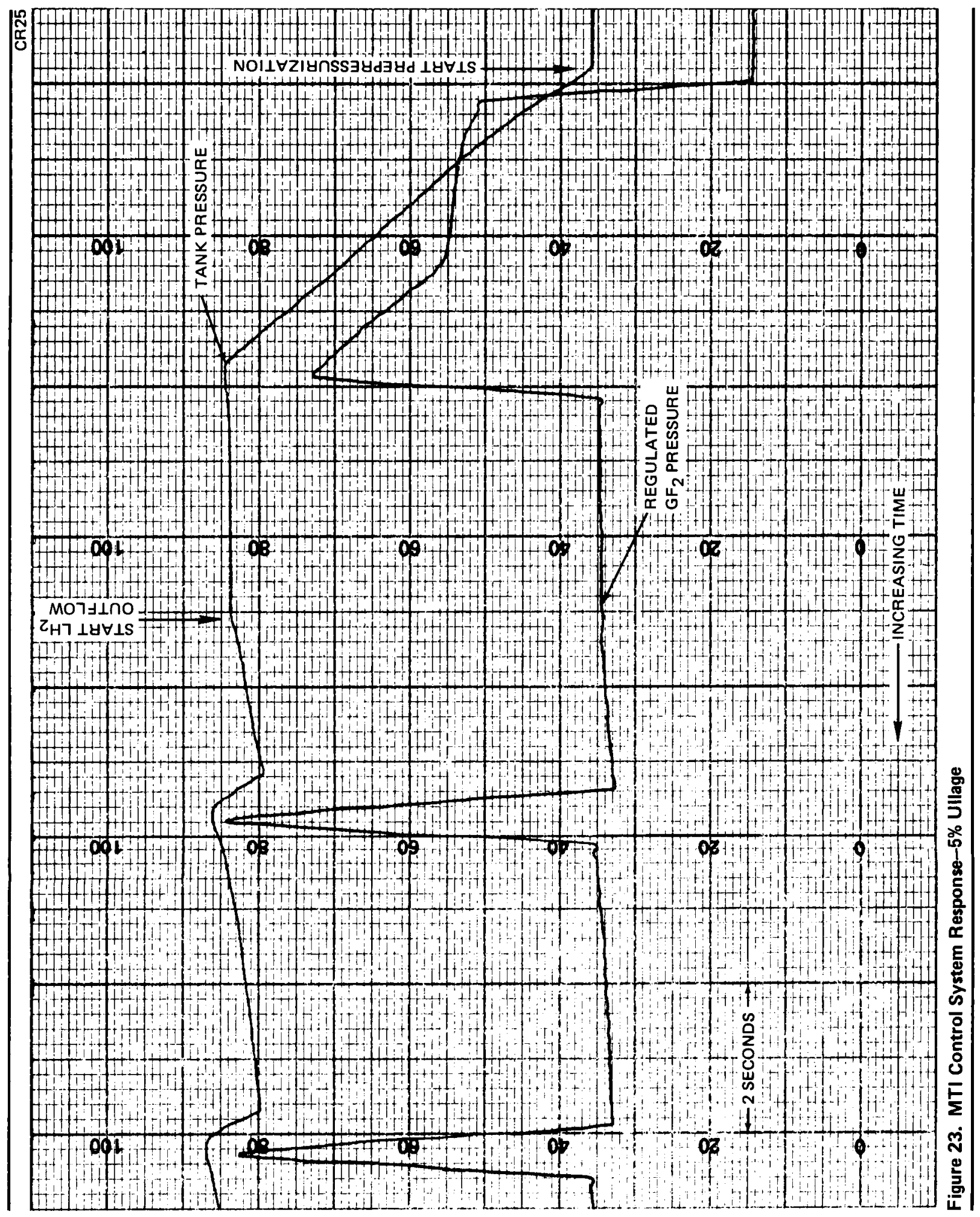


and provide regulation. The regulated pressure then follows (with some lag) the increasing tank pressure. The ON time fraction is quite low ( $<10$ percent during outflow and $<2$ percent during hold). Figure 24 shows the control system response for prepressurization of 50-percent ullage. Again, the tank pressure decay during hold is very slow, and the regulated pressure follows the same characteristic response curve. Figure 25 shows the dramatic change in injector valve cycle rate and $O N$ time fraction when outflow starts. It was noted in all tests that tank pressure was controlled to within $0.69 \mathrm{x}$ $10^{4} \mathrm{~N} / \mathrm{m}^{2}$ (1.0 psia) under essentially all conditions.

During the testing, it was observed that the $G_{2} F_{2}$ usage and the ullage temperatures were very low (about half) compared to those of the straight-pipe tests under Contract NAS3-13306. Detailed analysis and correlation of the $\mathrm{GF}_{2}$ usage ard ullage temperature history is described in the next section, Analysis and Comparison of Injectors. While testing was in progress, it was thought that the injector was aspirating as designed, with $\mathrm{GH}_{2}$ mass addition to the ullage responsible for keeping the ullage temperatures low, thus reducing $\mathrm{GF}_{2}$ usage. However, following the test series, which demonstrated excellent pressurization characteristics in every respect, the injector was removed from the tank and it was found that the nozzle diffuser downstream of the second stage throat was again damaged by overheating (see Figure 26). The $\mathrm{LH}_{2}$ pumping annulus was melted, and the damage was virtually identical to that sustained during the injector firing test. The melting was again apparently caused by insufficient pumping of $\mathrm{LH}_{2}$ in the second stage.

Analysis of the data indicated the regulator (which was suspected of causing the damage in the injector firing test) had performed in a nominal fashion. The injector thermocouples indicated steadily increasing 


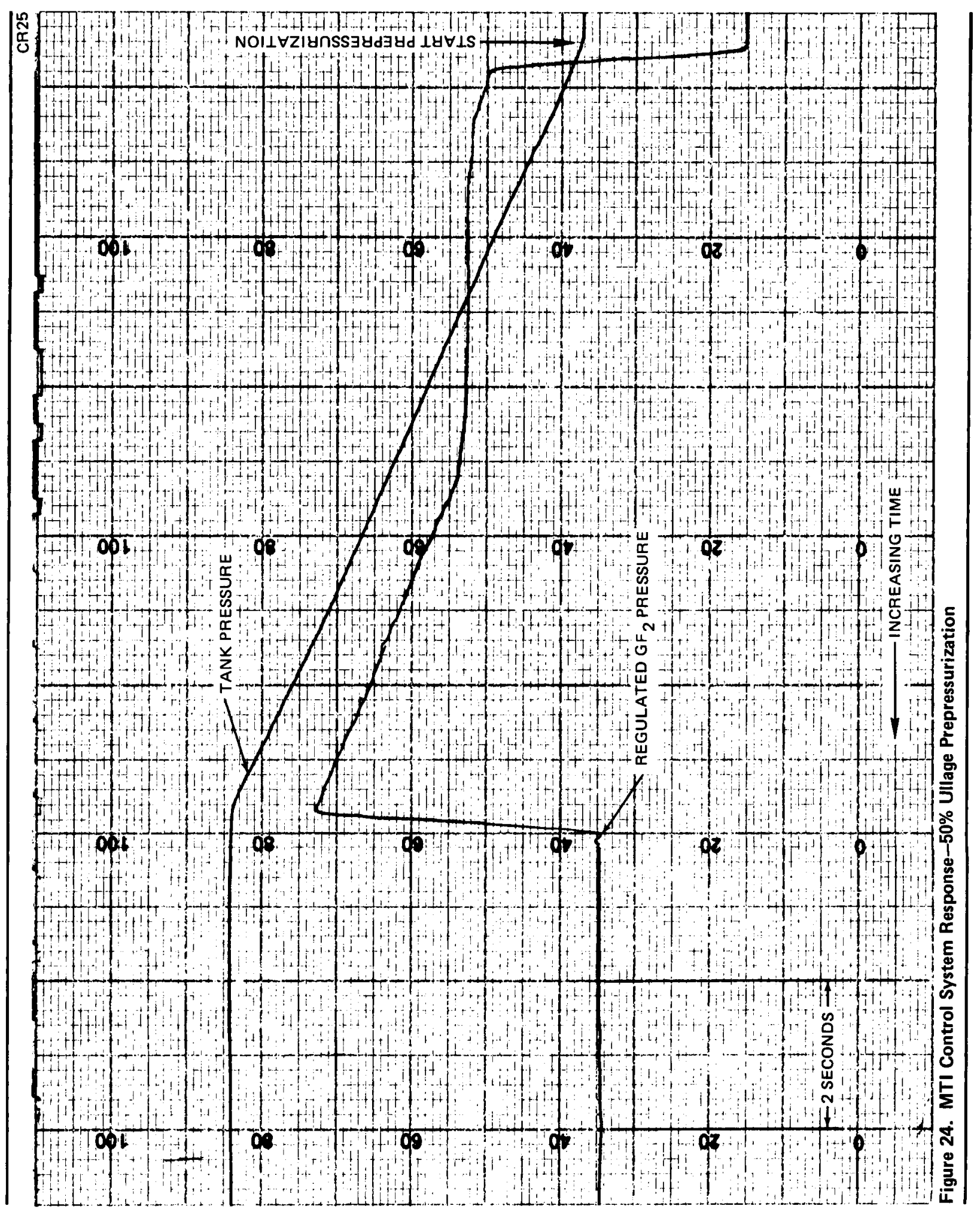




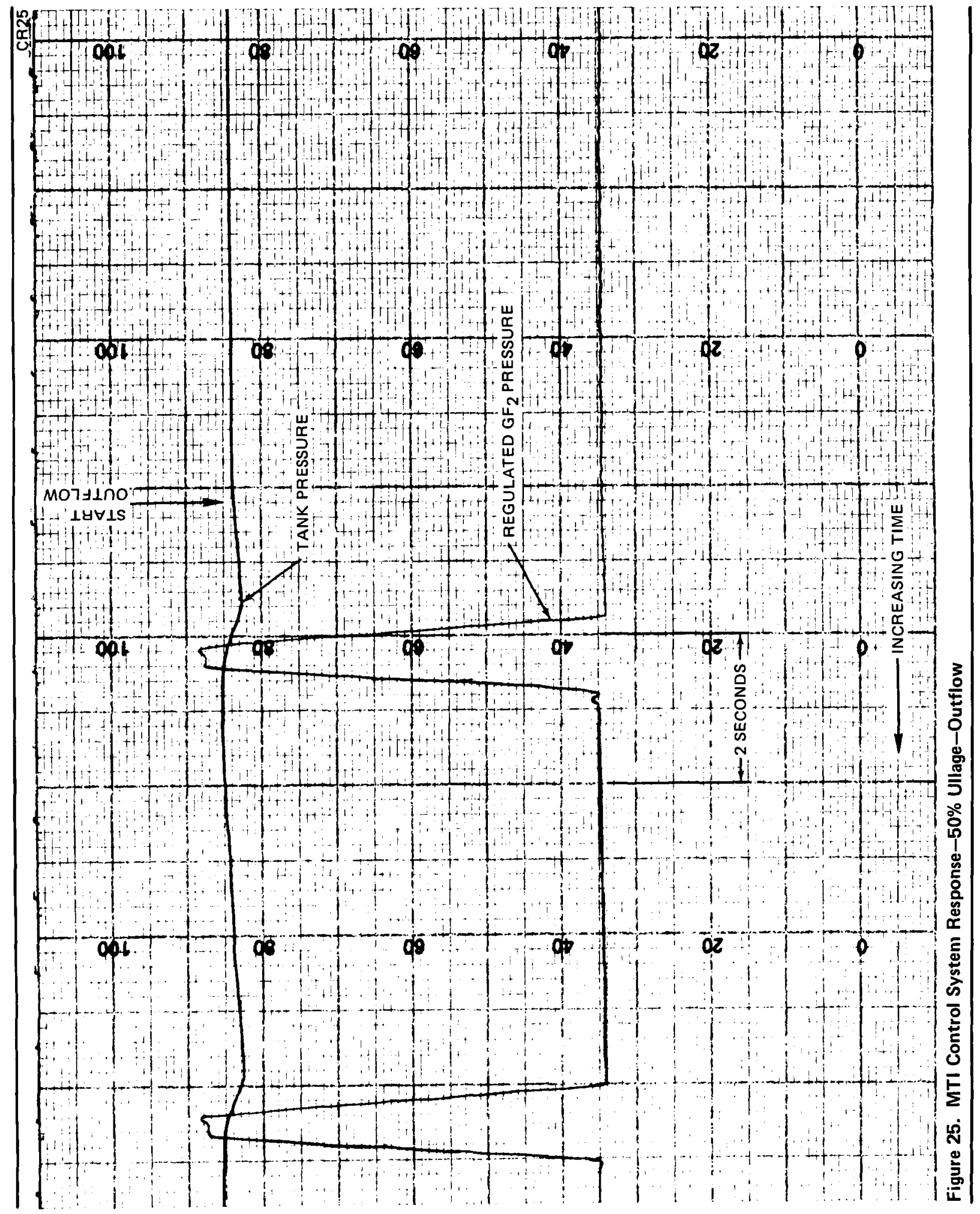






Figure 26. Injector Damage from Pressurization Tests 
temperatures (as soon as $\mathrm{GF}_{2}$ injection began) but stayed below the redline values. The most informative data were obtained from the temperature transducer ( $\mathrm{TL} 9$ ) in the $\mathrm{LH}_{2}$ feed line to the injector. The data from two tests are shown in Figure 27 on a vertical scale of $19.5^{\circ} \mathrm{K}\left(35^{\circ} \mathrm{R}\right)$ to $89^{\circ} \mathrm{K}\left(160^{\circ} \mathrm{R}\right)$. Figure $27(\mathrm{a})$, for 5 -percent initial ullage (test 5) with the tank nearly full, shows the initial temperature in the $\mathrm{LH}_{2}$ line to be $20^{\circ} \mathrm{K}\left(36^{\circ} \mathrm{R}\right)$. Immediately following injection, the temperature jumped upward. This jump is attributed to backflow in the $\mathrm{LH}_{2}$ line caused by the initial surge of $\mathrm{GF}_{2} \cdot$ Following this initial transient, the injector did pump $\mathrm{LH}_{2}$, as evidenced by a temperature drop to $21^{\circ} \mathrm{K}\left(38^{\circ} \mathrm{R}\right)$. However, as soon as $\mathrm{GF}_{2}$ flow was terminated following prepressurization, the $\mathrm{LH}_{2}$ line temperature jumped to a value of $69.5^{\circ} \mathrm{K}\left(125^{\circ} \mathrm{R}\right)$ which was an approximate equilibrium temperature determined by the injector temperature ( $\left.108^{\circ} \mathrm{K}\left[194^{\circ} \mathrm{R}\right]\right)$ and the ullage gas temperature $\left(\sim 36.7^{\circ} \mathrm{K}\left[66^{\circ} \mathrm{R}\right]\right)$ following prepressurization. The $\mathrm{LH}_{2}$ line temperature stayed at about $55^{\circ} \mathrm{K}\left(100^{\circ} \mathrm{R}\right)$ throughout the hold period because the injector valve did not cycle. However, as soon as $\mathrm{LH}_{2}$ outflow started and the injector valve cycled, the injector tried to a spirate (note the temperature dip) but the $\mathrm{LH}_{2}$ line temperature immediately went off scale when injection ceased for that cycle. This indicates that the injector can pump $\mathrm{LH}_{2}$ during steadystate operation with small ullages, but cannot aspirate $\mathrm{LH}_{2}$ when the injector becomes warm during cyclic operation.

Figure 27(b) shows the temperature history of the $\mathrm{LH}_{2}$ line for $90-$ percent initial ullage (test 7) with the tank nearly empty. The initial temperature in the $\mathrm{LH}_{2}$ inlet line was $30^{\circ} \mathrm{K}\left(54^{\circ} \mathrm{R}\right)$. During the 18 second prepressurization, the injector pumped $\mathrm{GH}_{2}$, as evidenced by the drop in temperature to $27.5^{\circ} \mathrm{K}\left(49.5^{\circ} \mathrm{R}\right)$ which is more than $5.5^{\circ} \mathrm{K}$ $\left(10^{\circ} \mathrm{R}\right)$ above the saturation temperature at $19.3 \times 10^{4} \mathrm{~N} / \mathrm{m}^{2}(28 \mathrm{psia})$. Again, following injection termination at the end of prepressurization, the temperature jumped to the vicinity of $50^{\circ} \mathrm{K}\left(90^{\circ} \mathrm{R}\right)$ where it pulsed 


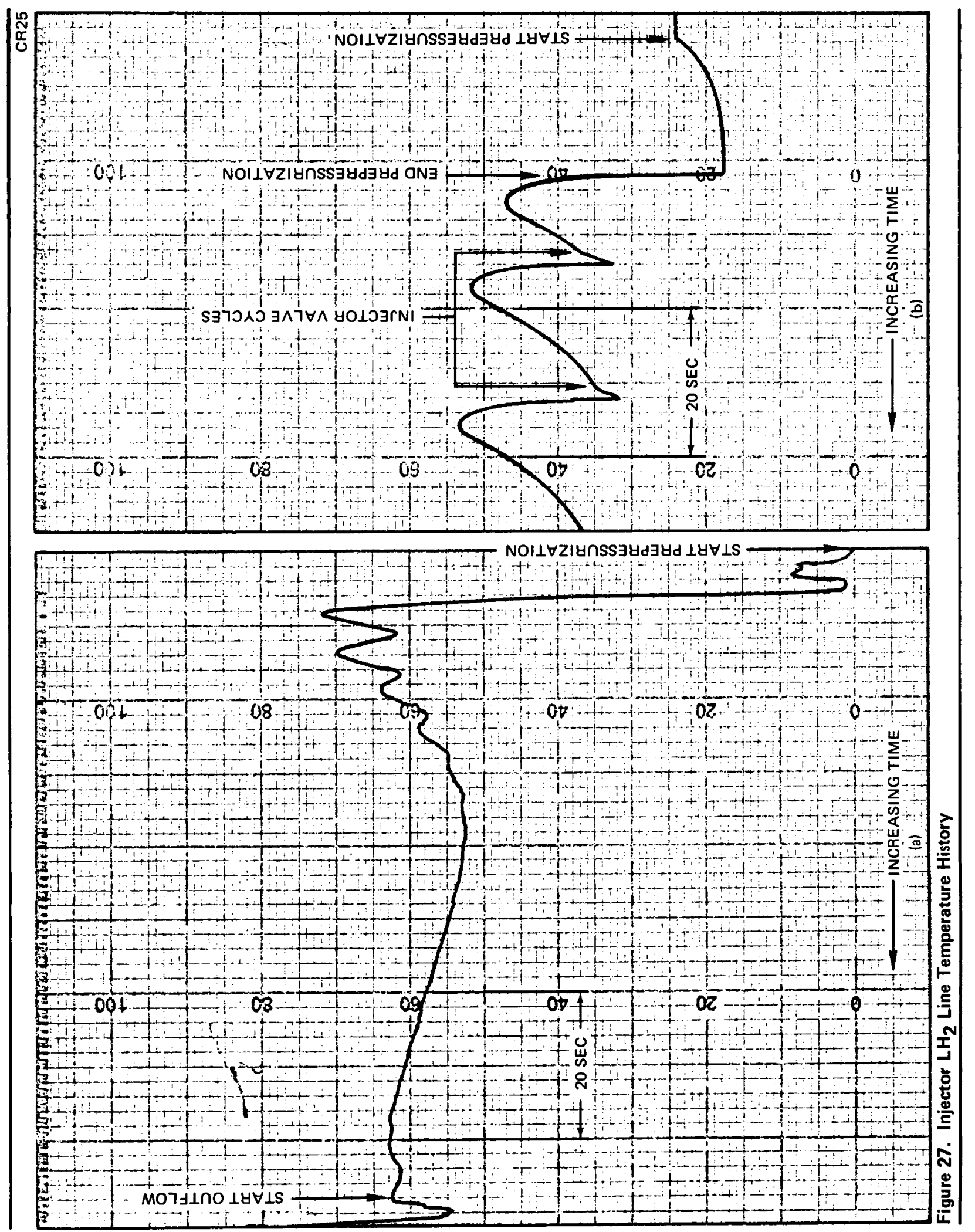


sharply downward with each injection cycle. This indicates that the injector was unable to pump $\mathrm{LH}_{2}$ up $5.8 \mathrm{~m}$ (19 ft) through the relatively warm ullage during the rather brief prepressurization.

It was probable that the injector damage occurred progressively throughout the test series, although a significant percentage of the damage may have occurred during the last test. The reason for this (and the basic reason for injector damage) was that the injector was designed to operate fuel-rich, at an $\mathrm{O} / \mathrm{F}$ weight ratio of about $1.8: 1$, when pumping $\mathrm{LH}_{2}$. The equilibrium combustion temperature at an $O / F$ ratio of $1.8: 1$ is $1,580^{\circ} \mathrm{K}\left(2,840^{\circ} \mathrm{R}\right)$, below the nickel 200 melting temperature of $1,715^{\circ} \mathrm{K}\left(3,090^{\circ} \mathrm{R}\right.$ ). If the injector pumped saturated $\mathrm{H}_{2}$ vapor (rather than $\mathrm{LH}_{2}$ ) through the same pumping area, the $\mathrm{O} / \mathrm{F}$ ratio would be $36: 1$ at a tank pressure of $30 \times 10^{4} \mathrm{~N} / \mathrm{m}^{2}$ (43 psia) with an equilibrium combustion temperature of $3,060^{\circ} \mathrm{K}\left(5,500^{\circ} \mathrm{R}\right)$. In addition, in the transition from $\mathrm{LH}_{2}$ to $\mathrm{GH}_{2}$ pumping, the injector $\mathrm{O} / \mathrm{F}$ ratio could pass through stoichiometric $(O / F=19)$ with an equivalent combustion temperature of $4,160^{\circ} \mathrm{K}\left(7,500^{\circ} \mathrm{R}\right)$.

In test 7 , when the injector was pumping $\mathrm{H}_{2}$ vapor at $27^{\circ} \mathrm{K}\left(49^{\circ} \mathrm{R}\right)$, assuming the design pumping area, the injector was operating at an $\mathrm{O} / \mathrm{F}$ ratio of about 70 (with an equivalent combustion temperature of $1,720^{\circ} \mathrm{K}\left[3,100^{\circ} \mathrm{R}\right]$ for up to 18 seconds. If the pumping a rea was larger (from annulus melting), more $\mathrm{GH}_{2}$ would have been pumped, with a lower $O / F$ ratio and higher combustion temperatures. Interestingly, the minimum $\mathrm{LH}_{2}$ flow area was the same after the testing damage as it was before. Although the annulus area was increased by melting from $0.449 \times 10^{-4} \mathrm{~m}^{2}\left(0.0696 \mathrm{in}^{2}\right.$ ) to $9.76 \times 10^{-4} \mathrm{~m}^{2}$ (1. 512 in. ${ }^{2}$ ), the $\mathrm{LH}_{2}$ inlet fitting was partially plugged by molten metal, reducing the original area of $0.895 \times 10^{-4} \mathrm{~m}^{2}\left(0.1386 \mathrm{in.}^{2}\right)$ to $0.448 \times 10^{-4} \mathrm{~m}^{2}\left(0.0693 \mathrm{in.}^{2}\right)$. However, the flow area was probably 
generally larger than the minimum during the testing so that the temperatures downstream of the second stage were probably in excess of $1,720^{\circ} \mathrm{K}\left(3,100^{\circ} \mathrm{R}\right)$, hence the melting of the nozzle diffuser.

The data indicate that the injector only pumps $\mathrm{LH}_{2}$ during prepressurization at 5-percent initial ullage. The consequences of this for pressurization are shown by the examples in Table 4.

It can be seen that the quantity of $\mathrm{H}_{2}$ pumped into the ullage by the injector is insignificant (and immeasurable) compared to the evaporated mass or the total ullage mass in all cases. Therefore, it appears that the injector did not perform its function of jet-pumping significant quantities of $\mathrm{H}_{2}$ into the ullage. However, the NAR injector did display superior pressurization performance, compared to the straight-pipe injector, with lower ullage temperatures and reduced $\mathrm{GF}_{2}$ usage. The reasons for this superior performance are that design features of the injector result in greater injection jet penetration, ullage mixing, and increased $\mathrm{LH}_{2}$ interface mass addition. These factors alone are the reasons for the superior performance, as will be described and analyzed in detail in the following section, Analysis and Comparison of Injectors. 
Table 4

INJECTOR $\mathrm{H}_{2}$ PUMPING PERFORMANCE

\begin{tabular}{|c|c|c|c|c|}
\hline & $\begin{array}{l}G F_{2} \\
\text { Usage* }\end{array}$ & \multirow{2}{*}{$\begin{array}{c}\text { Minimum } \\
\mathrm{O} / \mathrm{F} \\
\text { Ratio }\end{array}$} & \multicolumn{2}{|c|}{$\mathrm{H}_{2} \begin{array}{c}\text { Pumped into } \\
\text { Ullage }\end{array}$} \\
\hline & $(\mathrm{kg}) \quad(1 \mathrm{~b})$ & & (kg) & (lb) \\
\hline \multicolumn{5}{|l|}{ 5-Percent Ullage } \\
\hline Prepressurization & 0.0980 .216 & $1.8: 1$ & 0.0545 & 0.120 \\
\hline \multirow[t]{2}{*}{ Outflow } & $2.31 \quad 5.1$ & $36: 1$ & 0.0645 & 0.142 \\
\hline & & & 0.119 & 0.262 \\
\hline $\mathrm{H}_{2}$ added to ullage by interface & evaporation ${ }^{* *}$ & & 9.5 & 21 \\
\hline Total ullage mass ${ }^{* * *}$ & & & 12. 7 & 28 \\
\hline \multicolumn{5}{|l|}{ 50-Percent Ullage } \\
\hline Prepressurization and Outflow & $1.75 \quad 3.85$ & $36: 1$ & 0.0486 & 0.107 \\
\hline $\mathrm{H}_{2}$ added to ullage by interface & evaporation $* *$ & & 0 & 0 \\
\hline Total ullage mass $* *$ & & & 19.5 & 43 \\
\hline \multicolumn{5}{|l|}{ 90-Percent Ullage } \\
\hline Prepressurization (low pressure) & $0.276 \quad 0.607$ & $70: 1$ & 0.004 & 0.0087 \\
\hline $\mathrm{H}_{2}$ added to ullage by interface & evaporation $* *$ & & 0 & 0 \\
\hline Total ullage mass ${ }^{* * *}$ & & & 26.3 & 58 \\
\hline
\end{tabular}




\section{ANALYSIS AND COMPARISON OF INJECTORS}

The basic MTI pressurization analysis (MDAC computer code H819) developed under contract NAS3-13306 is reviewed in this section, followed by a comparison of experimental data from the straight-pipe tests (NAS3-13306) with data from the NAR injector tests. The analytic techniques required for correlation of the experimental data from the NAR injector pressurization tests are then discussed, followed by a description of the modifications of the H819 computer code required to allow performance prediction for straight-pipe, diffuser, and jet-pump injector types over the full range of hydrogen-fueled space vehicles.

\section{BASIC ANALYSIS}

The complete derivation of the MTI pressurization analysis is presented in Reference 2. Only the basic equations are summarized in this subsection.

The tank, propellant, and ullage are represented by a one-dimensional model. Variations in temperature and temperature-dependent properties occur only along the vertical tank axis with no radial or circumferential variations. This model is the basis for several analyses of conventional heated-gas tank pressurization (References 4, 5, 6) and its validity is well established. Buoyant forces caused by gravity or vehicle acceleration tend to produce a stable thermal stratification in the gas and liquid, resulting in a temperature distribution that is essentially one-dimensional. 
The computations are based on a finite difference representation of the physical system. The tank wall, internal hardware, propellant, and ullage are each divided by hórizontal planes into a number of nodes, as shown schematically in Figure 28, with the properties within each node being uniform. The axial thickness and location of the gas and liquid nodes can vary during the solution, while the wall and hardware nodes are of equal thickness and fixed.

Ullage mixing is a key feature of the MTI analysis. The injectant inflow causes gas mixing in the region near the injector, resulting in a nearly uniform temperature in the top part of the ullage. This mixed zone is represented by the large, single, upper gas node shown in Figure 28. Nonuniformities exist directly in the injectant flow path, particularly with the MTI flame; however, in the vicinity of the wall heat transfer surface, a nearly uniform temperature is maintained in the mixing zone.

The extent of the mixed ullage region is directly related to the depth of penetration into the ullage of the downward-flowing injectant jet. The velocity of this jet decreases with distance from its origin due to buoyancy because it is at higher temperature and lower density than the ullage and because of viscous mixing with the surroundings. These processes slow the jet to a zero axial velocity at some point, which is the jet penetration limit. An analysis for predicting this jet penetration depth was developed initially for nonreacting jets (Reference 7) and was extended to the reacting MTI case.

The basic equation for the deceleration of the jet centerline velocity due to buoyancy is

$$
I / 2 \rho_{j} d\left(U_{j}^{2}\right)=a\left(\rho_{j}-\rho_{u}\right) d X
$$




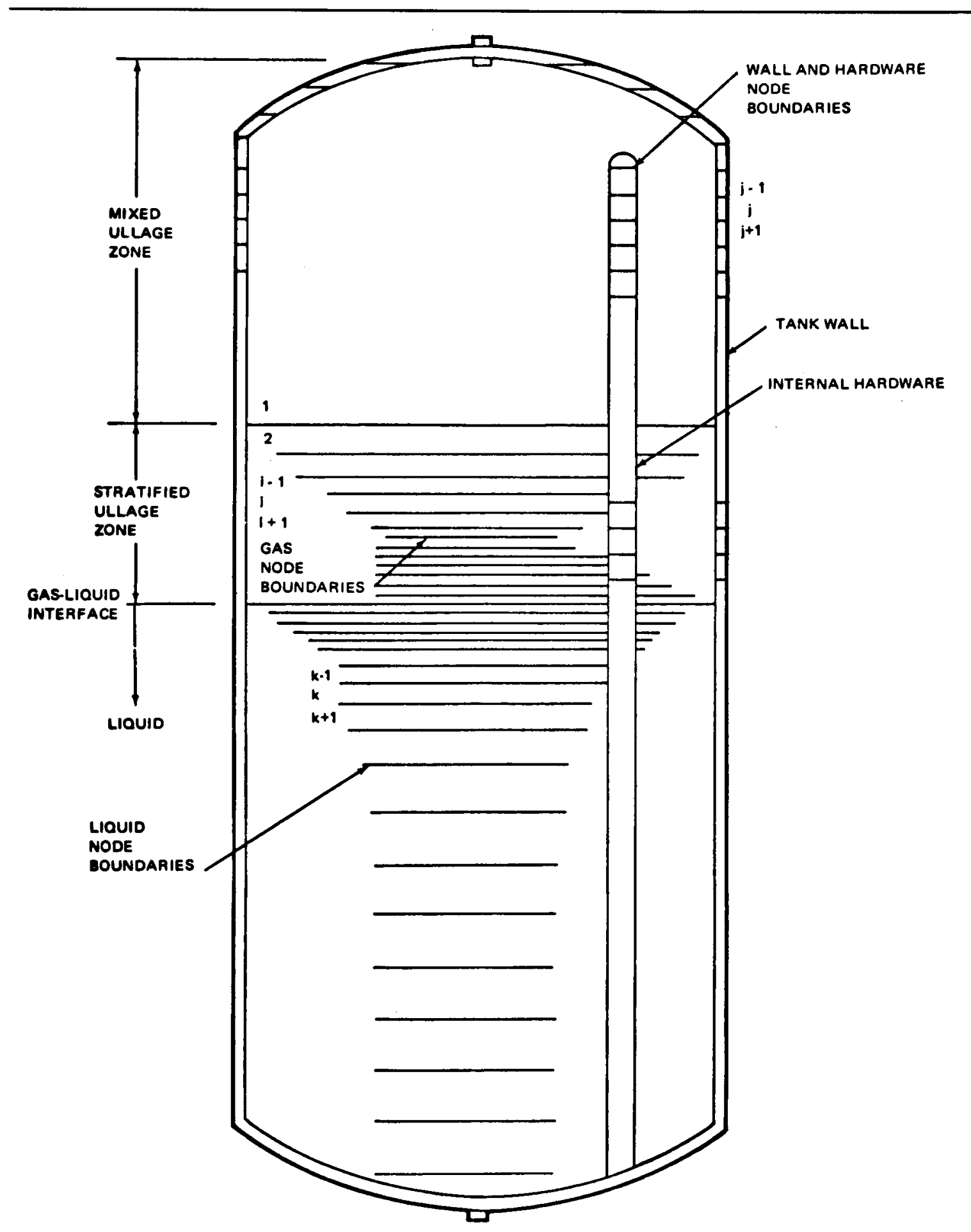

Figure 28. Finite Difference Node System 


$$
d\left(U_{j}{ }^{2}\right)=2 \mathrm{a}\left(1-\frac{\rho_{\mathrm{u}}}{\rho_{\mathrm{j}}}\right) \mathrm{dX}
$$

Because the ullage may be near $\mathrm{LH}_{2}$ temperatures initially, a compressibility factor is included in the equation for $\rho_{u}$, but the warmer jet is assumed to be a perfect gas; Equation (2) becomes

$$
d\left(U_{j}^{2}\right)=2 a\left(\begin{array}{cc}
I-\frac{T_{j}}{W_{j}} & \frac{W_{u}}{Z_{u}^{T} T_{u}}
\end{array}\right) d X
$$

where $T_{j}$ is the temperature and $W_{j}$ is the molecular weight on the centerline of the jet, both of which vary with distance $X$ in the flame structure. The variation in velocity because of turbulent jet mixing must also be specified.

For the nonreacting jet analysis (Reference 7 ), the equations of Laufer (Reference 8) were used for $T_{j}, W_{j}$, and the velocity decay caused by jet mixing. The same equation form is used for the reacting jet. The centerline velocity variation caused only by viscous mixing is assumed to be unaffected by the MTI reaction:

$$
\frac{U_{j}}{U_{j o}}=\frac{X_{c}}{X} \quad X>X_{c}
$$


where $X_{c}$ is the velocity core length. The temperature equation is modified by using the flame length $X_{F}$ as the effective temperature core length:

$$
\frac{T_{j}-T_{0}}{T_{j m}-T_{0}}=\frac{X_{F}}{X} \quad X>X_{F}
$$

In the flame region, a linear increase in centerline temperature is as sumed:

$$
\frac{T_{j}-T_{j o}}{T_{j m}-T_{j o}}=\frac{X-X_{c}}{X_{F}-X_{c}} \quad X_{c}<X \leq X_{F}
$$

and $T_{j}$ remains equal to $T_{j o}$ in the velocity core region $\left(X<X_{c}\right)$. The centerline gas composition is also given by Equations (5) and (6), replacing the left side of both by $Y_{j}$, the mass fraction of $H F$ which is equal to one at the maximum temperature point and zero in the surrounding medium, and at the jet exit. The jet centerline molecular weight is then given by

$$
W_{j}=\frac{W_{0} W_{H F}}{Y_{j}\left(W_{0}-W_{H F}\right)+W_{H F}}
$$

where $W_{0}=W_{I_{2}}$ for $X>X_{F}$ and $W_{0}=W_{F_{2}}$ for $X_{c}<X \leq X_{F}$.

The values of $X_{C}$ and $X_{F}$ were determined empirically. The velocity core length was evaluated from nonreacting jet test data (Reference 9).

$$
x_{c}=23.0\left[\rho_{j o} d^{2} / 8 \rho_{u}\right]^{1 / 2}
$$


The flame length was measured from photographic data taken during the NAS3-7963 tests (Reference 1) and defined as

$$
x_{F}=x_{c}+67 d
$$

where both $X_{C}$ and $X_{F}$ are measured from the jet exit.

The centerline velocity-squared decrement caused by buoyancy forces on the hot, downward flowing jet is found by combining and integrating the above equations, giving three different equations for the three regions of the jet structure: the velocity core, the flame zone, and beyond the flame zone.

Velocity core zone $\left(X \leq X_{C}\right)$ :

$\left.\Delta\left(U_{j}^{2}\right)_{b}\right|_{X_{1}} ^{x_{2}}=2 a\left(1-\frac{T_{j o} W_{H_{2}}}{{ }_{F_{2}}{ }^{{ }_{u}{ }^{T}}}\right)\left(x_{2}-x_{l}\right)$

Fiame zone $\left(X_{C}<X \leq X_{F}\right)$ :

$$
\begin{aligned}
\left.\Delta\left(U_{j}^{2}\right)_{b}\right|_{X_{1}} ^{X_{2}}= & 2 a\left\{A\left(x_{2}-x_{1}\right)\right. \\
& +\frac{B}{2}\left[\left(x_{2}-x_{c}\right)^{2}-\left(x_{1}-x_{c}\right)^{2}\right] \\
& \left.+\frac{C}{3}\left[\left(x_{2}-x_{c}\right)^{3}-\left(x_{1}-x_{c}\right)^{3}\right]\right\}
\end{aligned}
$$


where

$$
\begin{aligned}
& A=1-\frac{T_{j o} W_{H_{2}}}{W_{F_{2}} Z_{u} T_{u}} \\
& B=-\frac{W_{H_{2}}\left[T_{j o}\left(W_{F_{2}}-W_{H F}\right)+W_{H F}\left(T_{j m}-T_{j o}\right)\right]}{W_{F_{2}} W_{H F} Z_{u} T_{u}\left(X_{F}-X_{c}\right)} \\
& C=-\frac{W_{H_{2}}\left(W_{F_{2}}-W_{H F}\right)\left(T_{j m}-T_{j o}\right)}{W_{F_{2}} W_{H F} Z_{u} T_{u}\left(X_{F}-X_{c}\right)^{2}} .
\end{aligned}
$$

Beyond the flame zone $\left(X>X_{F}\right)$ :

$$
\begin{aligned}
\left.\Delta\left(U_{j}{ }^{2}\right)_{b}\right|_{X_{1}} ^{X_{2}}= & 2 a\left[D\left(x_{2}-X_{1}\right)+E \ln \left(\frac{x_{2}}{x_{1}}\right)\right. \\
& \left.-F\left(\frac{1}{x_{2}}-\frac{1}{x_{1}}\right)\right]
\end{aligned}
$$

where

$$
D=1-\frac{T_{0}}{Z_{u} T_{u}}
$$




$$
\begin{aligned}
& E=-\frac{X_{F}\left[T_{0}\left(W_{H_{2}}-W_{H F}\right)+W_{H F}\left(T_{j m}-T_{0}\right)\right]}{W_{H F} Z_{u} T_{u}} \\
& E=-\frac{x_{F}{ }^{2}\left(W_{H_{2}}-{ }^{W}{ }_{H F}\right)\left(T_{j m}-T_{o}\right)}{W_{H F} Z_{u \cdot} T_{u}}
\end{aligned}
$$

In all regions of the jet flow, the centerline velocity-squared decrement from locations $X_{1}$ to $X_{2}$ caused by turbulent mixing with the surrounding ullage is given by

$$
\left.\Delta\left(U_{j}^{2}\right)_{M}\right|_{X_{1}} ^{x_{2}}=U_{j o}^{2} x_{c}^{2}\left(\frac{1}{x_{2}^{2}}-\frac{1}{x_{1}^{2}}\right)
$$

from Equation (4). The total centerline velocity-squared decrement is the sum of the mixing and buoyancy contributions

$$
\left.\Delta\left(U_{j}{ }^{2}\right)\right|_{X_{1}} ^{x_{2}}=\left.\Delta\left(U_{j}^{2}\right)_{M}\right|_{X_{1}} ^{x_{2}}+\left.\Delta\left(U_{j}^{2}\right)_{b}\right|_{X_{1}} ^{x_{2}}
$$

where the mixing contribution is zero when $\mathrm{X}<\mathrm{X}_{\mathrm{c}}$. 
Equation (14) determines the jet penetration depth $\mathrm{X}_{\mathrm{p}}$ at which the centerline velocity has decreased to zero. The depth of the mixed ullage zone $X_{\text {mix }}$ may be less than $X_{p}$; therefore,

$$
x_{\text {mix }}=f_{m} x_{p}
$$

defines a mixing fraction factor $\mathrm{f}_{\mathrm{m}}$, which is a measure of the effectiveness of the ullage mixing.

The jet penetration and ullage partial-mixing models are of primary importance to the overall MTI pressurization analysis. All heat released by the flame goes into the mixed zone because this is the region directly affected by the injectant flow. Forced convection heat transfer to the tank wall occurs in this region due to the agitation caused by the gas mixing. The heat and mass transfer at the gasliquid interface are determined by the injectant jet penetration because the dominant mode of interface heat transfer results from direct impingement of the injectant flow upon the liquid surface. Other aspects of the analysis are similar to that of a conventional heated-gas pressurization system.

The MTI pressurization computer program (H819) incorporating the above features includes essentially all capabilities of existing pressurization programs: variable properties for the gas, liquid, wall, and internal hardware; unrestricted tank configuration; injectant supply system computations; operating parameters specified by either timevariable tabular inputs or internal calculations, and a number of different operating modes. In normal usage, the fluorine supply system and propellant outflow rates are specified and the computer program calculates the temperature distributions in the wall, hardware, liquid, and gas, as well as the liquid vaporization rate and tank pressure, all 
of which vary with time during the solution. These data may be output from the program as frequently as desired.

\section{COMPARISON OF INJECTORS}

During pressurization testing, it was obvious that the NAR injector was maintaining a much colder ullage and was using much less $\mathrm{GF}_{2}$ than was the case during the straight-pipe injector tests conducted under contract NAS3-13306. Fortunately, the test conditions often were practically identical for both the NAR injector and straight-pipe injector tests (see Table 2). For example, Test 2 from the NAS3-13306 tests is comparable to Test 3 from this program. Both tests had 50-percent initial ullage, operated at a tank pressure of $30 \times 10^{4} \mathrm{~N} / \mathrm{m}^{2}(43 \mathrm{psia})$, and had essentially identical $\mathrm{LH}_{2}$ outflow rates and test times. The ullage gas temperature history for both tests is shown in Figures $29 a, b$, and c. It is obvious from Figures $29 \mathrm{~b}$ and $29 \mathrm{c}$ that the NAR injector has greater jet penetration and ullage mixing than the straight-pipe. Figures $29 \mathrm{~b}$ and $29 \mathrm{c}$ also illustrate the acceleration of temperature rise when the ullage gets warm. This leads to increased heat transfer, $\mathrm{GF}_{2}$ demand, higher temperatures, etc., until the $\mathrm{GF}_{2}$ flow is on all the time, which leads to in-tank circulation and stratification, as shown by lest 2 results shown in Figure 29c (Reference 2). A comparison of $\mathrm{GF}_{2}$ usage for the tests is shown in Table 5.

Table 5

$\mathrm{GF}_{2}$ USAGE COMPARISON

\begin{tabular}{ccccc}
\hline & \multicolumn{2}{c}{$\begin{array}{c}\text { Test 3, NAS3-14381 } \\
\text { (NAR Injector) }\end{array}$} & \multicolumn{2}{c}{$\begin{array}{c}\text { Test 2, NAS3-13306 } \\
\text { (Straight-Pipe) }\end{array}$} \\
\cline { 2 - 5 } Ullage Level & $\mathrm{kg}$ & $\mathrm{lb}$ & $\mathrm{kg}$ & $1 \mathrm{~b}$ \\
\hline $\begin{array}{l}\text { End prepres } \\
\text { surization }\end{array}$ & 0.253 & 0.557 & 0.585 & 1.290 \\
$50 \%$ & 0.365 & 0.803 & 0.785 & 1.730 \\
$35 \%$ & 0.765 & 1.687 & 1.650 & 3.630 \\
$20 \%$ & 1.145 & 2.522 & 2.550 & 5.630 \\
$10 \%$ & 1.750 & 3.850 & 3.030 & 6.680 \\
\hline
\end{tabular}


CR25

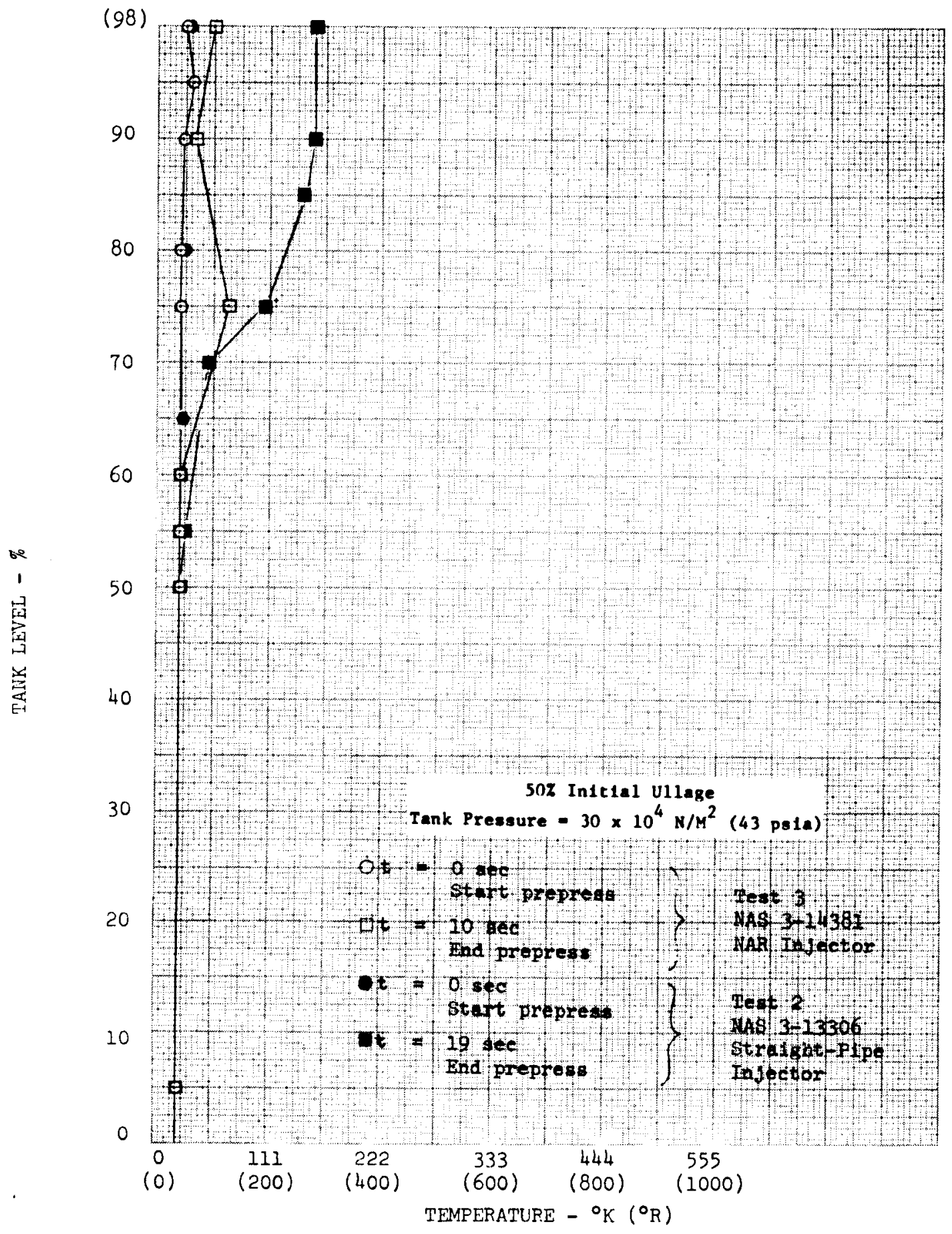

Figure 29a. Ullage Gas Temperature Comparison, 50-Percent Ullage 


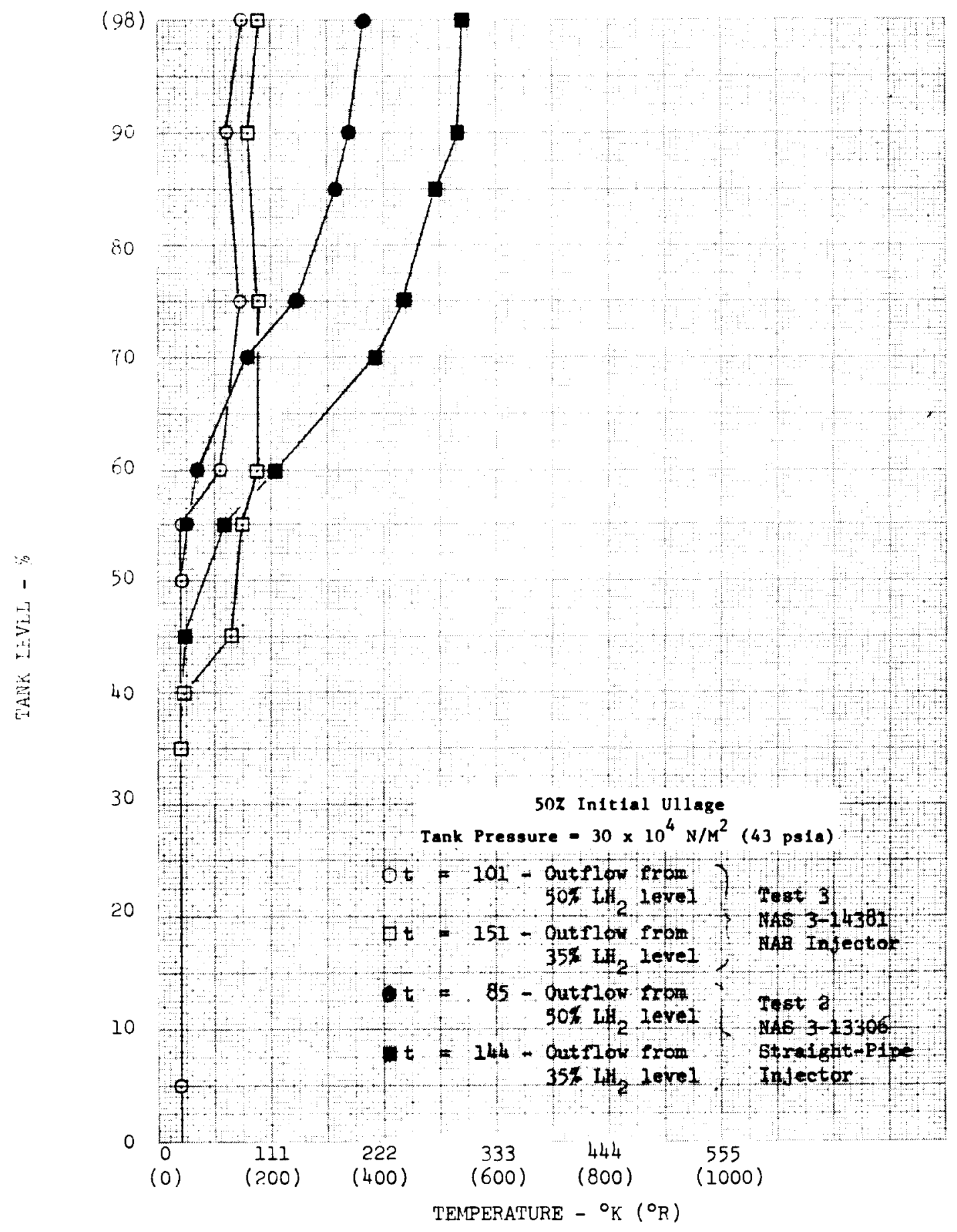

Figure 29b. Ullage Gas Temperature Comparison, 50-Percent Ullage 


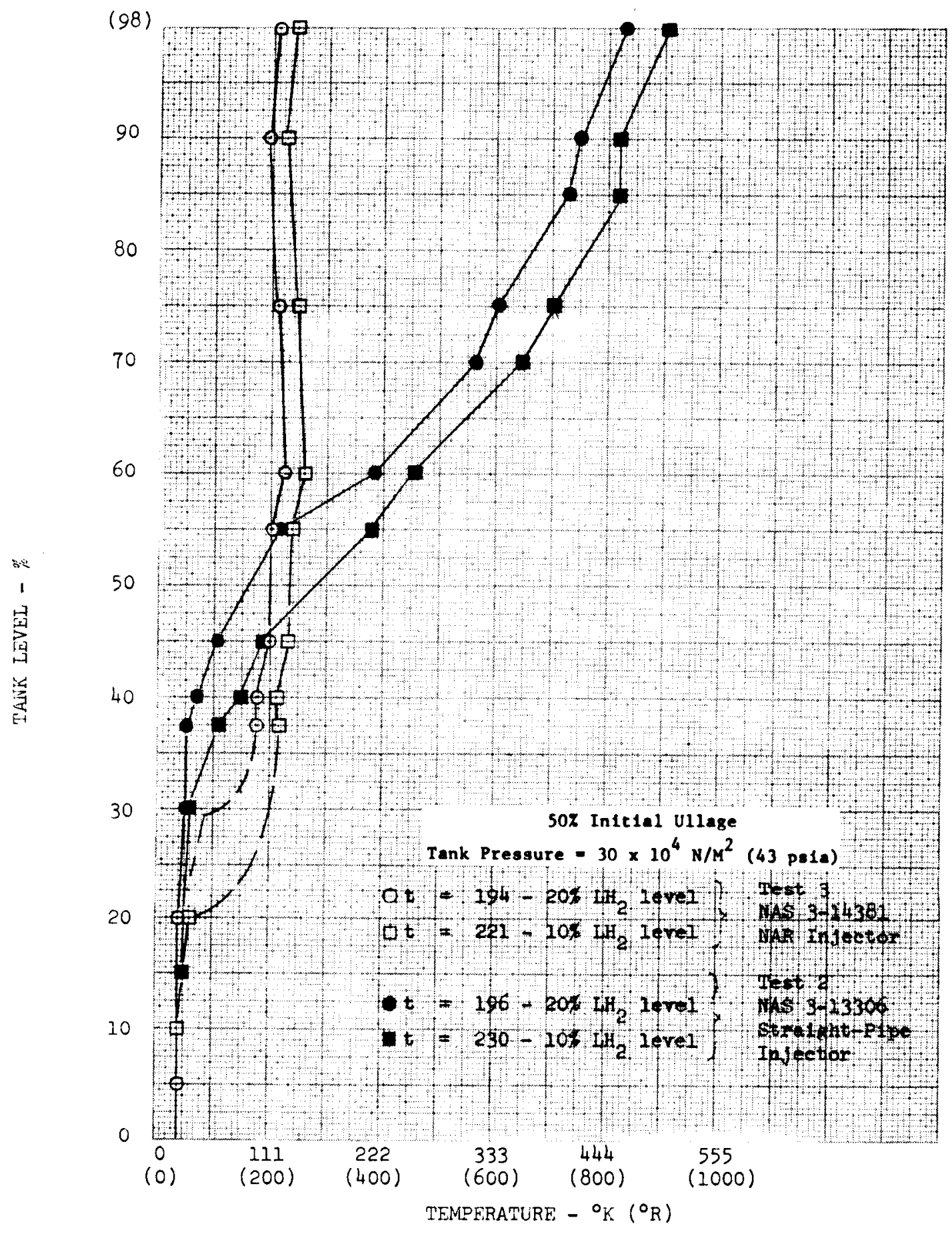

Figure 29c. Ullage Gas Temperature Comparison, 50-Percent Ullage 
The NAR injector consistently used about half as much $\mathrm{GF}_{2}$ as the straight-pipe injector, which is a direct indication of the NAR injector's superior jet penetration and mixing, and demonstrates the importance of these parameters.

Test 7 from the NAS3-13306 tests and Test 5 from this program also were compared. Both tests had 5-percent initial ullage, operated at a tank pressure of $18.6 \times 10^{4} \mathrm{~N} / \mathrm{m}^{2}(27 \mathrm{psia})$, and has essentially identical $\mathrm{LH}_{2}$ flow rates and test times. The ullage gas temperature history for these tests is shown in Figures $30 a, b, c$, and $d$. It can be seen from Figures $30 \mathrm{a}$ and $30 \mathrm{~b}$ that the temperatures and penetration for the two injectors are essentially the same down to the 65-percent level. At that point, the straight-pipe temperatures rise rapidly and diverge from the NAR injector data (see Figures 30c and 30d). This, basically, is because the NAR injector has greater evaporation of $\mathrm{LH}_{2}$ at the interface, and therefore lower ullage temperatures. The GF 2 usage and $\mathrm{LH}_{2}$ evaporation are compared in Table 6 . The table data show that the $\mathrm{GF}_{2}$ usage is also close, down to the 65-percent level, before the straight-pipe $G_{2}$ usage increases rapidly. In fact, the NAR injector uses $0.036 \mathrm{~kg}(0.08 \mathrm{lb})$ more $\mathrm{GF}_{2}$ than the straight-pipe at the $80-$ and 65-percent levels. This extra GF 2 goes directly into the increased $\mathrm{LH}_{2}$ evaporation of $1.36 \mathrm{~kg}(3.0 \mathrm{lb})$ that the NAR injector shows at the 80 - and 65-percent levels, (The combustion energy from $0.036 \mathrm{~kg}$ [0.08 lb] of $\mathrm{GF}_{2}$ can evaporate $1.18 \mathrm{~kg}[2.6 \mathrm{lb}]$ of $\mathrm{LH}_{2}$.) For the straight pipe, the $\mathrm{LH}_{2}$ evaporation stops at the 65-percent level (when the liquid penetration by the jet ceases), but the NAR injector, with its superior jet penetration, continues to penetrate the liquid and evaporate $\mathrm{LH}_{2}$ down to nearly the 35-percent level. The large evaporation numbers shown in parentheses in Table 6 are in error, and are caused by the linear extrapolation from the 40 -percent level down, due to inoperable temperature sensors at the se levels. In actuality, the NAR 


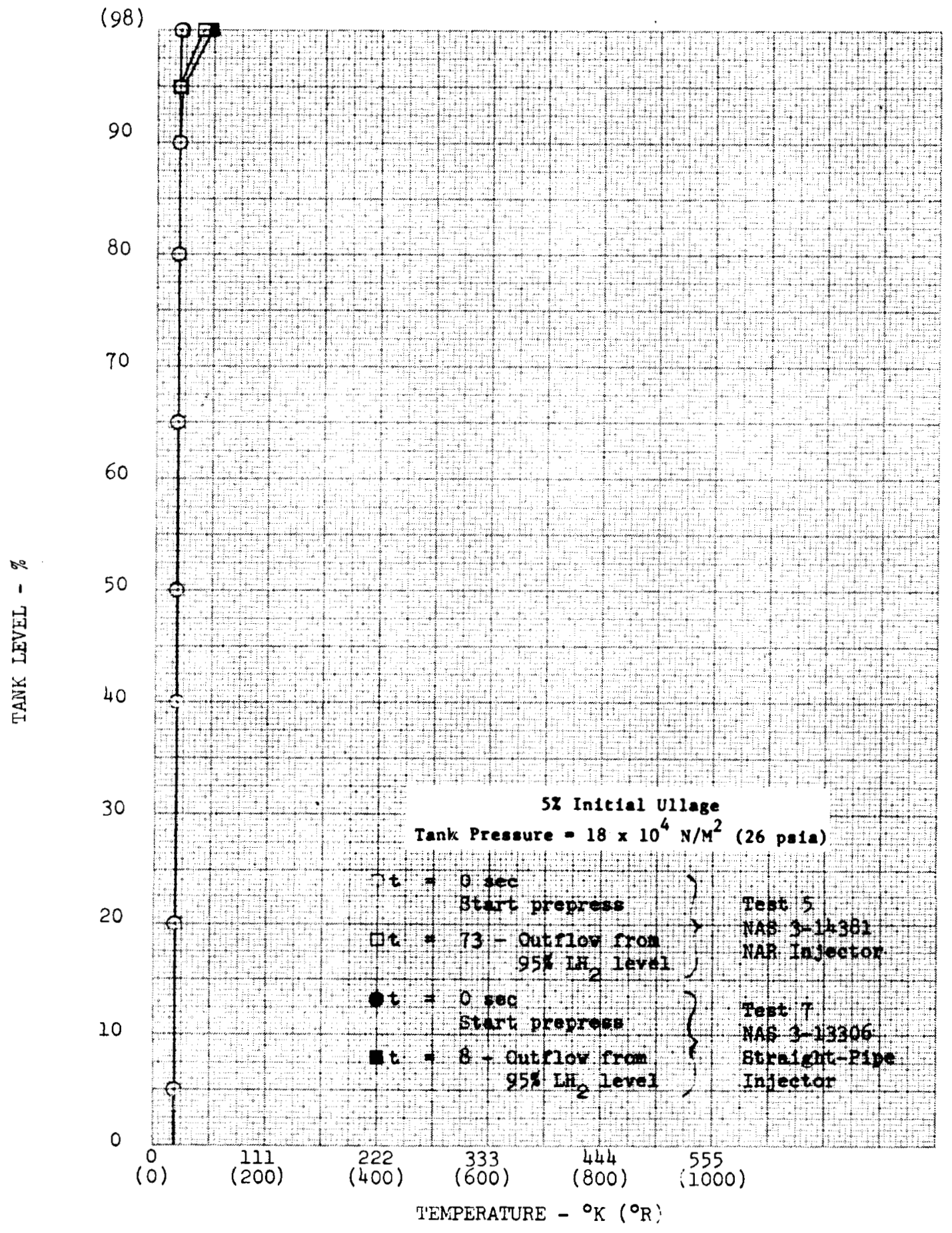

Figure 30a. Ullage Gas Temperature Comparison, 5-Percent Ullage 


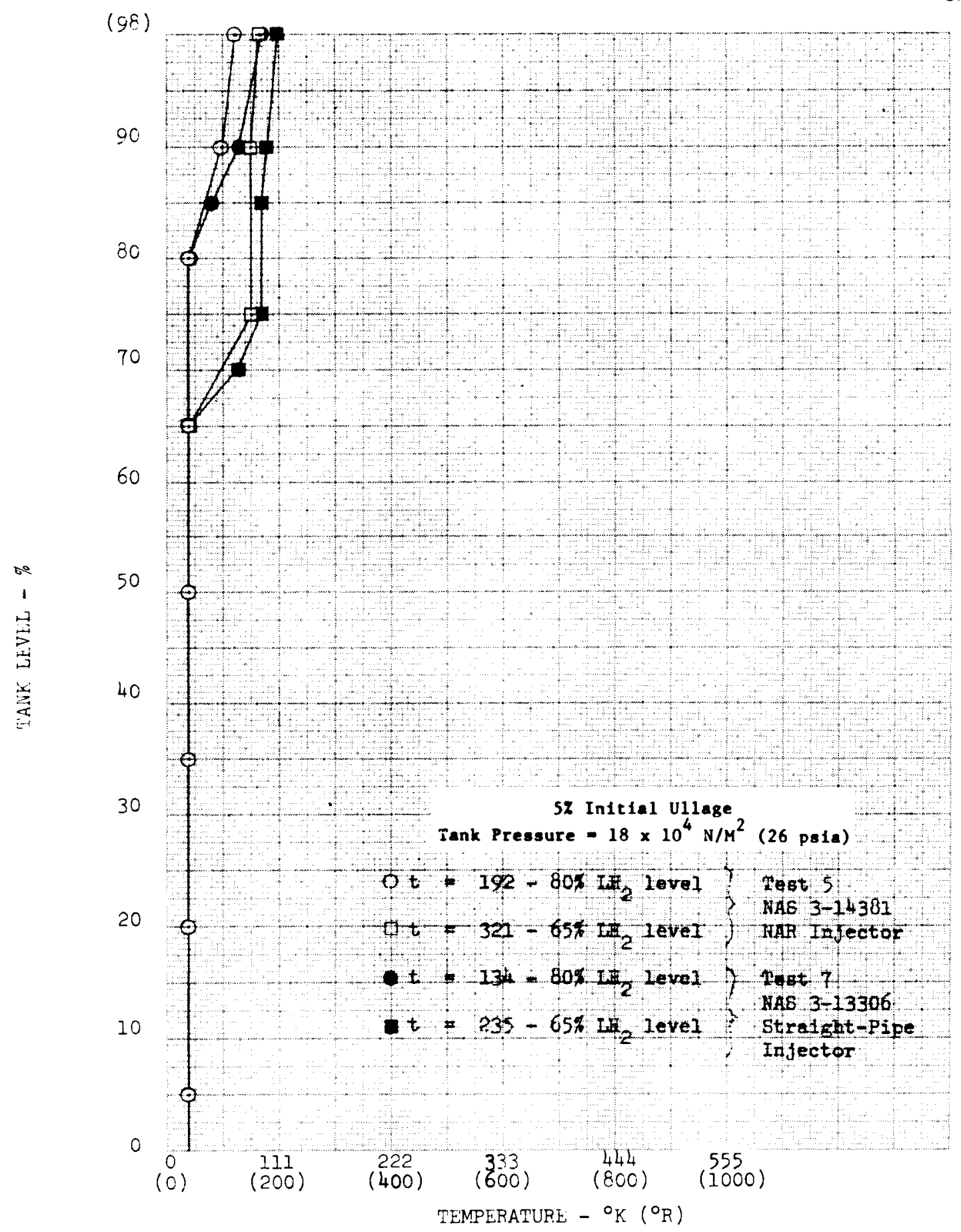

Figure 30b. Ullage Gas Temperature Comparison, 5-Percent Ullage 


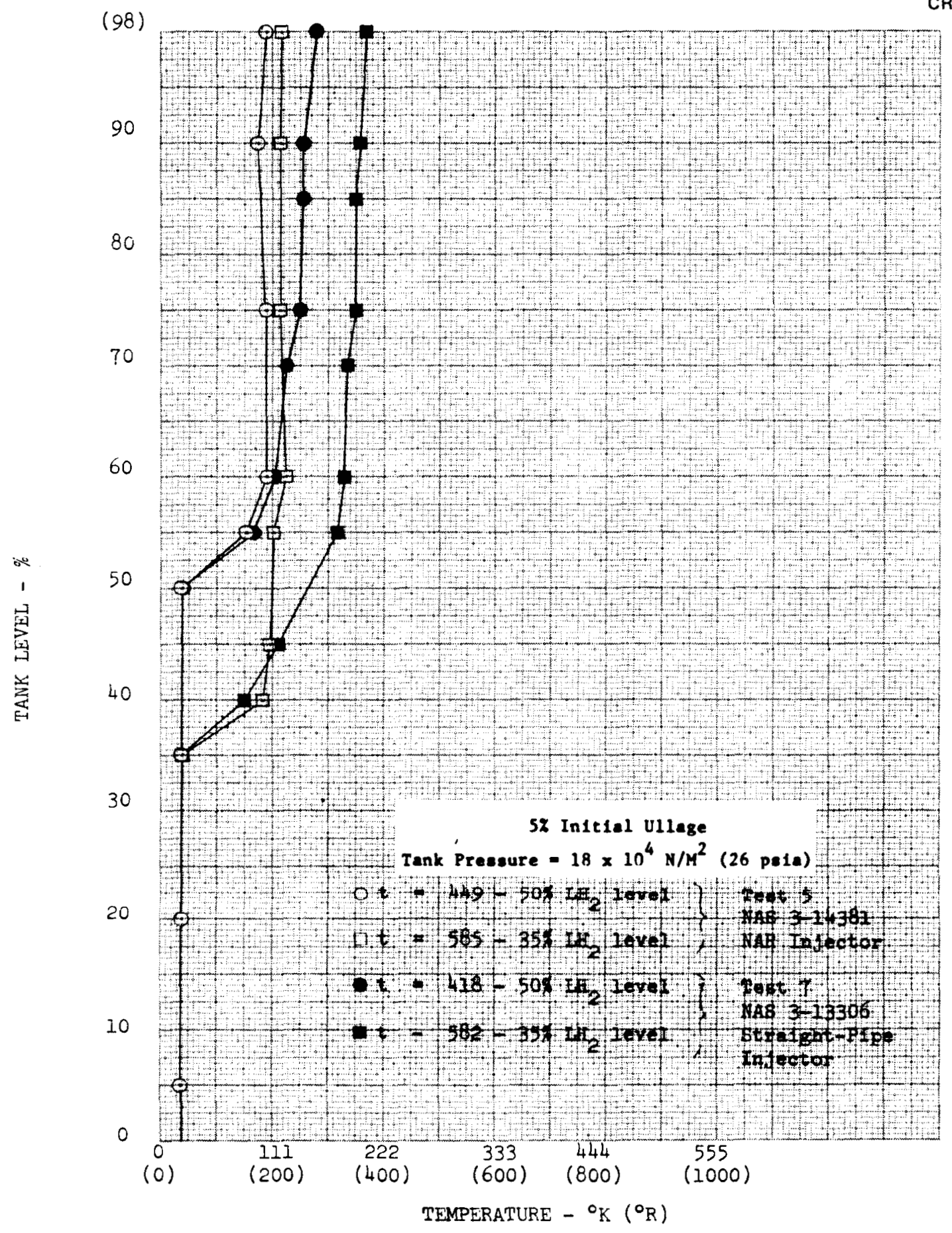

Figure 30c. Ullage Gas Temperature Comparison, 5-Percent Ullage 


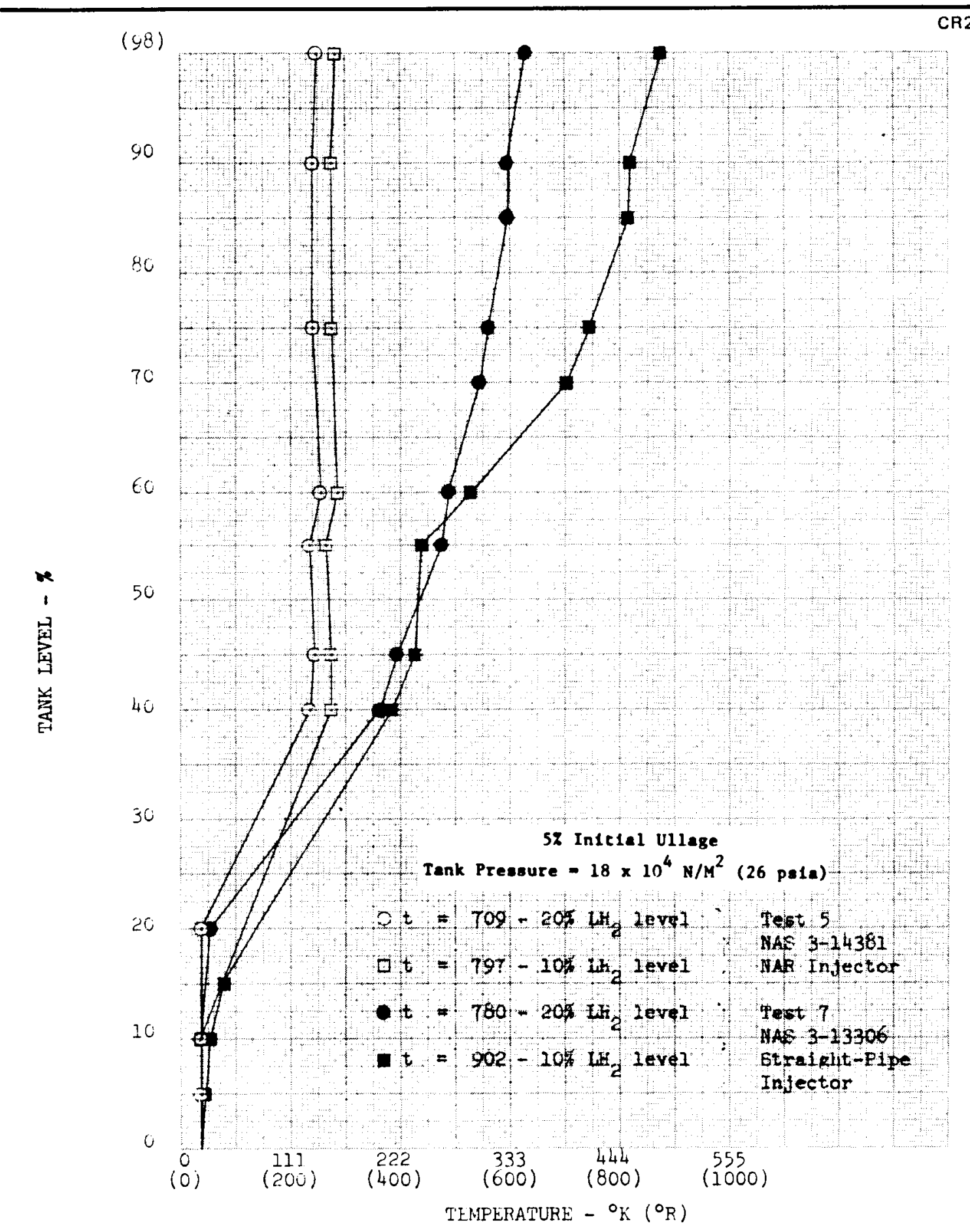

Figure 30d. Ullage Gas Temperature Comparison, 5-Percent Ullage 


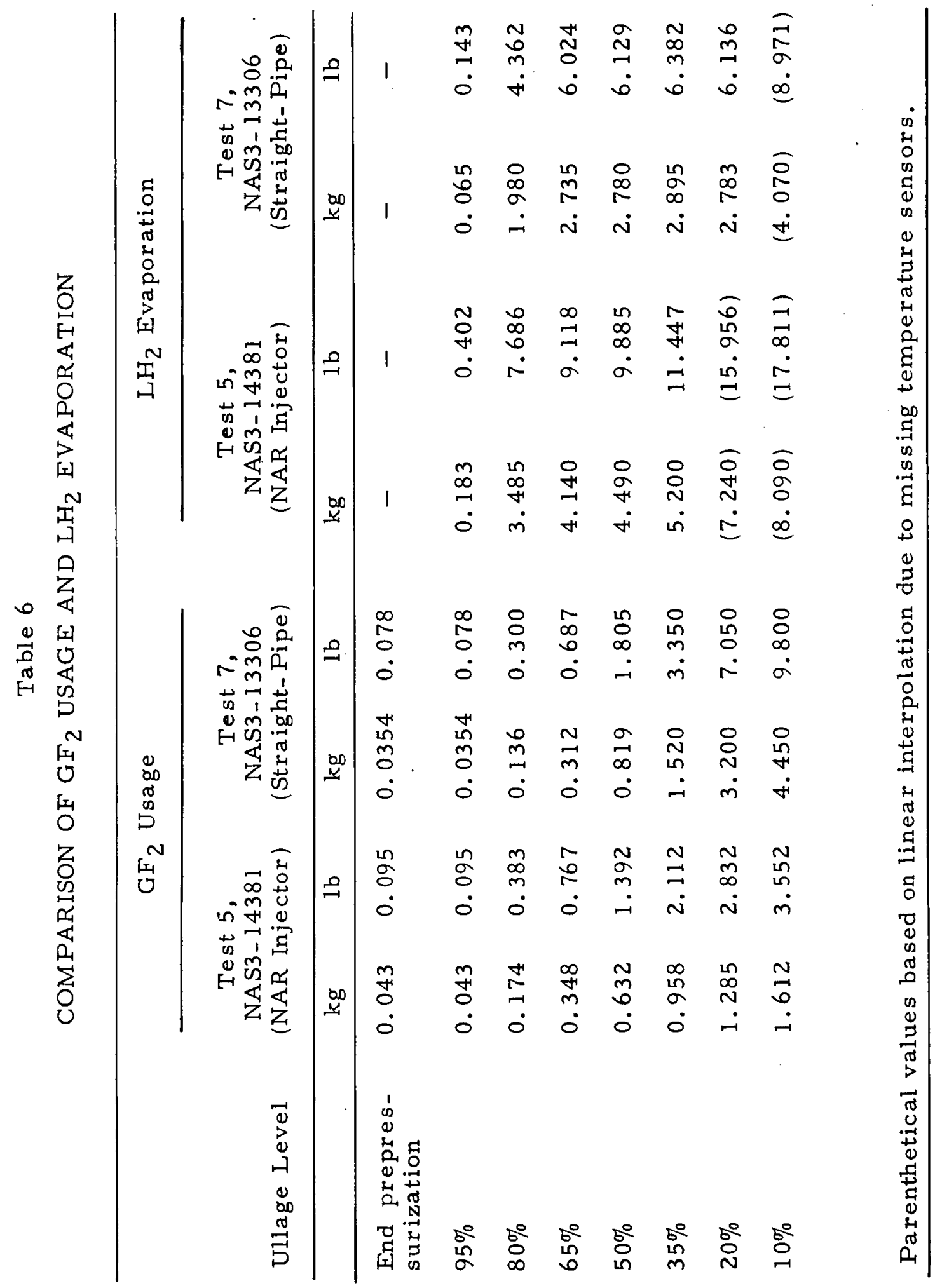


injector doubtless penetrates several feet further than shown, which. would give evaporation values in line with the $5.2 \mathrm{~kg}(11.45 \mathrm{lb})$ shown. Development of jet penetration, interface heat transfer, and tank wall heat transfer models to allow prediction of ullage temperatures, $G_{2}$ usage, and $\mathrm{LH}_{2}$ evaporation for the NAR injector are described in the following section. 


\section{ANALYTIC CORRELATION WITH EXPERIMENTAL DATA}

\section{Ullage Gas Temperature and $\mathrm{GF}_{2}$ Usage}

Two of the most important parameters in the prediction of MTI injector performance are $\mathrm{GF}_{2}$ usage and the temperature of the ullage gas (which directly affects both tank wall heating and $\mathrm{GF}_{2}$ usage). These parameters are directly related to the degree of ullage mixing. With good ullage mixing, the ullage gas temperature is lower, heat transfer to the wall is lower, and $\mathrm{GF}_{2}$ requirements therefore are minimized. The reverse is also true: Poor mixing results in higher ullage temperature, higher heat transfer, and greater $\mathrm{GF}_{2}$ usage. If the ullage is completely mixed to the depth of the predicted injectant penetration, the mixing fraction factor, $f_{m}$, equals 1.0 (see Equation 15). If $\mathrm{f}_{\mathrm{m}}<1.0$, the injectant jet penetration itself is not directly affected, but the mixed depth is less, and thus the temperature in the mixed region is higher.

In the previous investigation under NAS3-13306 (Reference 2), for those tests with large initial ullages (no interface mass transfer) and high tank pressures, where the $\mathrm{GF}_{2}$ requirements demanded large injector on-time fractions, the ullage gas temperatures were correlated by assuming $f_{m}=0.8$. But the low-pressure cases, where smalle $\mathrm{GF}_{2}$ requirements were satisfied by small on-time fractions, temperatures were correlated by assuming $\mathrm{f}_{\mathrm{m}}=0.9$. The difference was possibly due to an ullage circulation flow field which occurred with long on-time fractions, and led to temperature stratification in the tank and reduced ullage mixing. The tests with the NAR injector were all characterized by very short injector on-time fractions, and deep, uniform temperature profiles, so that the correlation was done with an assumed $\mathrm{f}_{\mathrm{m}}=0.9$. 
The processes occurring in the NAR injector are much more complex than in the simple straight pipe previously tested. The injectant gas flow at the injector exit is likely to have nonuniform distribution of temperature, composition, and velocity, and it is not obvious how the jet penetration process should be modeled. It was first assumed that the mixing between the $\mathrm{GF}_{2}$ stream and the aspirated $\mathrm{GH}_{2}$ in the second stage diffuser was no different than that occurring for a $G_{2}$ flow into an unconfined ullage. The jet-exit parameters were set for the conditions at the second stage venturi exit. This high-velocity, small-diameter jet did not give adequate ullage penetration for $\mathrm{GF}_{2}$ inlet temperature of either $333^{\circ} \mathrm{K}\left(600^{\circ} \mathrm{R}\right)$ or $555^{\circ} \mathrm{K}\left(1,000^{\circ} \mathrm{R}\right)$. It was then assumed that the $\mathrm{GF}_{2}$ flow from the second stage venturi went through a normal shock to become subsonic and then filled the entire $3.3 \times 10^{-2}-\mathrm{m}\left(1.3-\right.$ in. ) diameter injector width, with negligible $\mathrm{GH}_{2}$ flow. The analysis again predicted insufficient ullage penetration depth and excessive ullage temperature even with $f_{m}=1.0$, as shown in Figure 31 for test 3 (50-percent initial ullage). The lines shown indicate the predicted mixed-zone depth and temperature (the stratified ullage below the mixed zone is not shown for clarity) compared to the experimental points. It seems clear that the injector was pumping enough hydrogen to affect the behavior of the jet.

If the injector was assumed to be pumping $\mathrm{GH}_{2}$ at a large $\mathrm{O} / \mathrm{F}$ ratio (for example, 36), the weight of pumped $\mathrm{H}_{2}$ was small, but the molar flow of the low-molecular weight $\mathrm{H}_{2}$ is nearly half that of the $\mathrm{GF}_{2}$ and is enough to effectively confine the $\mathrm{GF}_{2}$ flow, thus giving higher injectant velocity and penetration. The following equations indicate this effect:

$$
\mathrm{U}=\frac{\dot{\mathrm{m}} \mathrm{J}}{\rho_{\mathrm{J}} \mathrm{A}}
$$




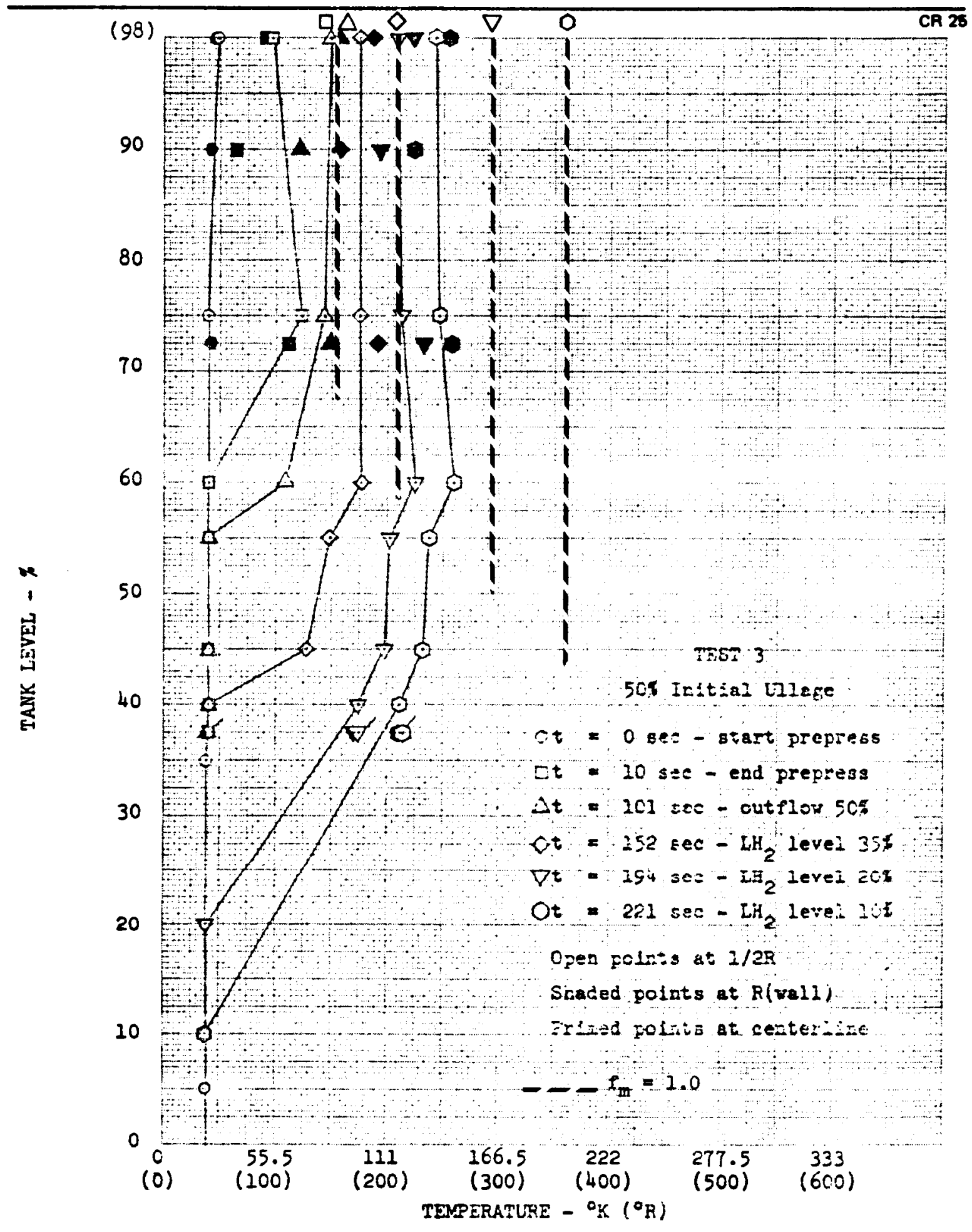

Figure 31. Temperature Correlation for Test 3, NAS3-14381, Zero $\mathrm{H}_{2}$ Aspiration 
assuming perfect gas,

$$
\rho_{J}=\frac{P}{\frac{R}{\bar{W}_{J}} T_{J}}
$$

substituting in (16)

$$
\mathrm{U}=\frac{\dot{\mathrm{m}}_{\mathrm{J}}}{\mathrm{W}_{\mathrm{J}}} \frac{\mathrm{RT}_{\mathrm{J}}}{\mathrm{PA}}
$$

and

$$
\frac{\dot{\mathrm{m}}_{\mathrm{J}}}{\mathrm{W}_{\mathrm{J}}}=\frac{\dot{\mathrm{m}}_{\mathrm{F}_{2}}}{\mathrm{~W}_{\mathrm{F}_{2}}}+\frac{\dot{\mathrm{m}}_{\mathrm{H}_{2}}}{\mathrm{~W}_{\mathrm{H}_{2}}}=\frac{\dot{\mathrm{m}}_{\mathrm{F}_{2}}}{\mathrm{~W}_{\mathrm{F}_{2}}}+\frac{\dot{\mathrm{m}}_{\mathrm{F}_{2}}}{(\mathrm{O} / \mathrm{F}) \mathrm{W}_{\mathrm{H}_{2}}}
$$

substituting in (18)

$$
\mathrm{U}=\left(\frac{1}{\mathrm{~W}_{\mathrm{F}_{2}}}+\frac{1}{(\mathrm{O} / \mathrm{F}) \mathrm{W}_{\mathrm{H}_{2}}}\right)^{\frac{\dot{\mathrm{m}}_{\mathrm{F}_{2}} \mathrm{RT}_{\mathrm{J}}}{\mathrm{PA}}}
$$

In addition, some of the $\mathrm{GF}_{2}$ combusts inside the injector and thus contributes to increased injectant velocity by raising the mean effective jet temperature $\left(\mathrm{T}_{\mathrm{J}}\right.$ in Equation 20$)$. This does not mean that the flow is mixed and at an average temperature, but rather that the mean velocity of the jet corresponds to the mean effective temperature. For example, if 9 percent of the $\mathrm{GF}_{2}$ combusts with pumped $\mathrm{GH}_{2}$ in the injector, then $\mathrm{T}_{\mathrm{J}}$ would equal $1,111^{\circ} \mathrm{K}\left(2,000^{\circ} \mathrm{R}\right)$, assuming the $\mathrm{GF}_{2}$ from the first stage is at $333^{\circ} \mathrm{K}\left(600^{\circ} \mathrm{R}\right)$.

The $O / F$ ratio and mean effective temperature determine the jet-exit velocity. The jet-centerline properties for the penetration depth 
analysis are determined by the unreacted core of the jet pump flow, that is, pure $\mathrm{GF}_{2}$ at $333^{\circ} \mathrm{K}\left(600^{\circ} \mathrm{R}\right)$. The jet pump outflow is presumed to be a central core of $\mathrm{GF}_{2}$ surrounded by an outer sheath of pumped $\mathrm{GH}_{2}$ which join in a mixing/reaction zone. Extremely high temperatures occur in the reaction zone, resulting in a higher mean temperature for the total flow although most of the $\mathrm{GF}_{2}$ core will be unaffected. The $\mathrm{GF}_{2}$ temperature is that resulting from combustion in the first stage of the injector. The design $\mathrm{O} / \mathrm{F}=800$ with a temperature of $555^{\circ} \mathrm{K}\left(1,000^{\circ} \mathrm{R}\right)$ assumes $\mathrm{LH}_{2}$ enters the heat exchanger in the first stage feed line. Experimental data indicate that $\mathrm{GH}_{2}$ entered the heat exchanger, which gives a much higher $\mathrm{GH}_{2}$ inlet temperature to the first stage combustor, higher $\mathrm{O} / \mathrm{F}$ ratio, and lower combustion product temperature; therefore, the first stage temperature was set at $333^{\circ} \mathrm{K}$ $\left(600^{\circ} \mathrm{R}\right)$.

Based on the above assumptions $\left(\mathrm{O} / \mathrm{F}=36 ; \mathrm{T}_{\mathrm{J}}=1,111^{\circ} \mathrm{K}\left[2,000^{\circ} \mathrm{R}\right]\right)$, the ullage gas mixed-zone temperature history was predicted for the large ullage volume tests (3, 6, 7, and 2) as shown in Figures 32, 33, 34, and 35. The agreement is excellent, except for Test 2, a warm initial ullage case with small on-time fractions where $f_{m}=0.9$ gave excessive ullage temperatures and $\mathrm{GF}_{2}$ usage. The same situation was encountered in Test 13 from NAS3-13306, also a warm initial ullage test with small on-time fraction, and the data from test 13 were best correlated with $\mathrm{f}_{\mathrm{m}}=1.0$. It was postulated at the time that the warm initial ullage resisted establishment of the ullage circulation field, but substantiation of this thesis was not possible. However, Test 2 from this program was also well correlated with $f_{m}=1.0$, so that an ullage temperature effect does in fact seem to act in these cases.

In addition to accurate jet penetration predictions, the heat transfer characteristics from the ullage gas must be known to accurately 


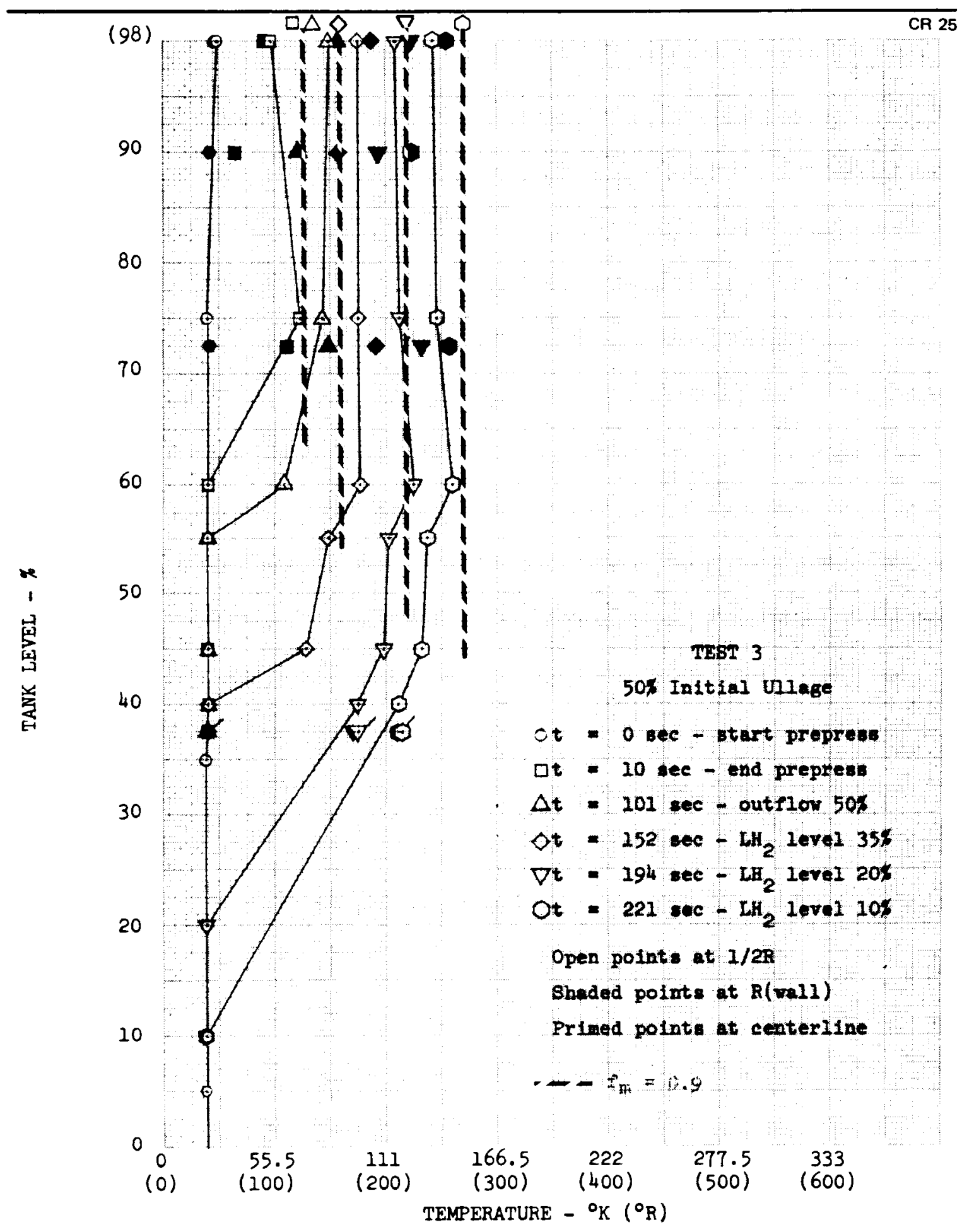

Figure 32. Temperature Correlation for Test 3, NAS3-14381, With $\mathrm{H}_{2}$ Aspiration 




Figure 33. Temperature Correlation for Test 6, NAS3-14381 


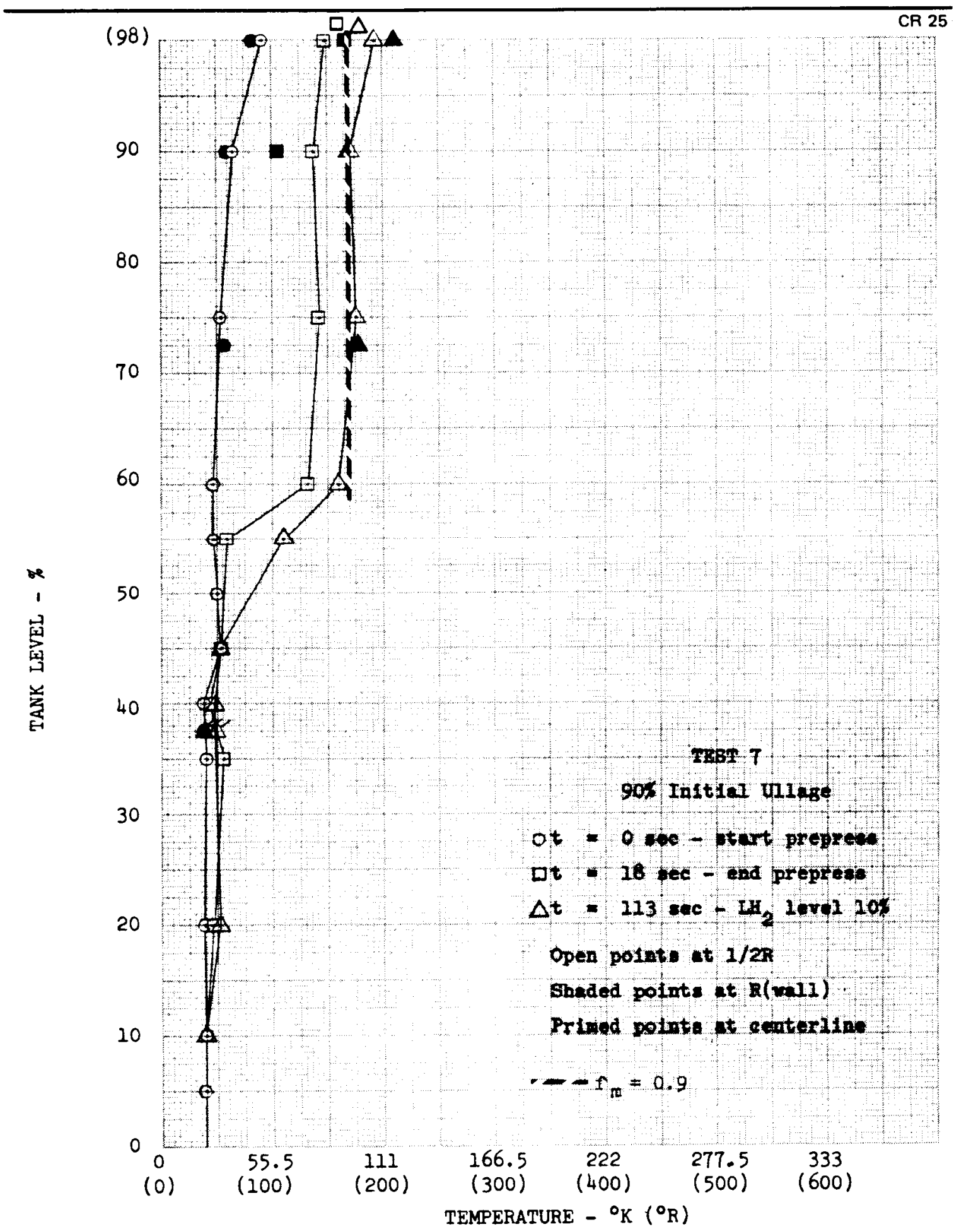

Figure 34. Temperature Correlation for Test 7, NAS3-14381 


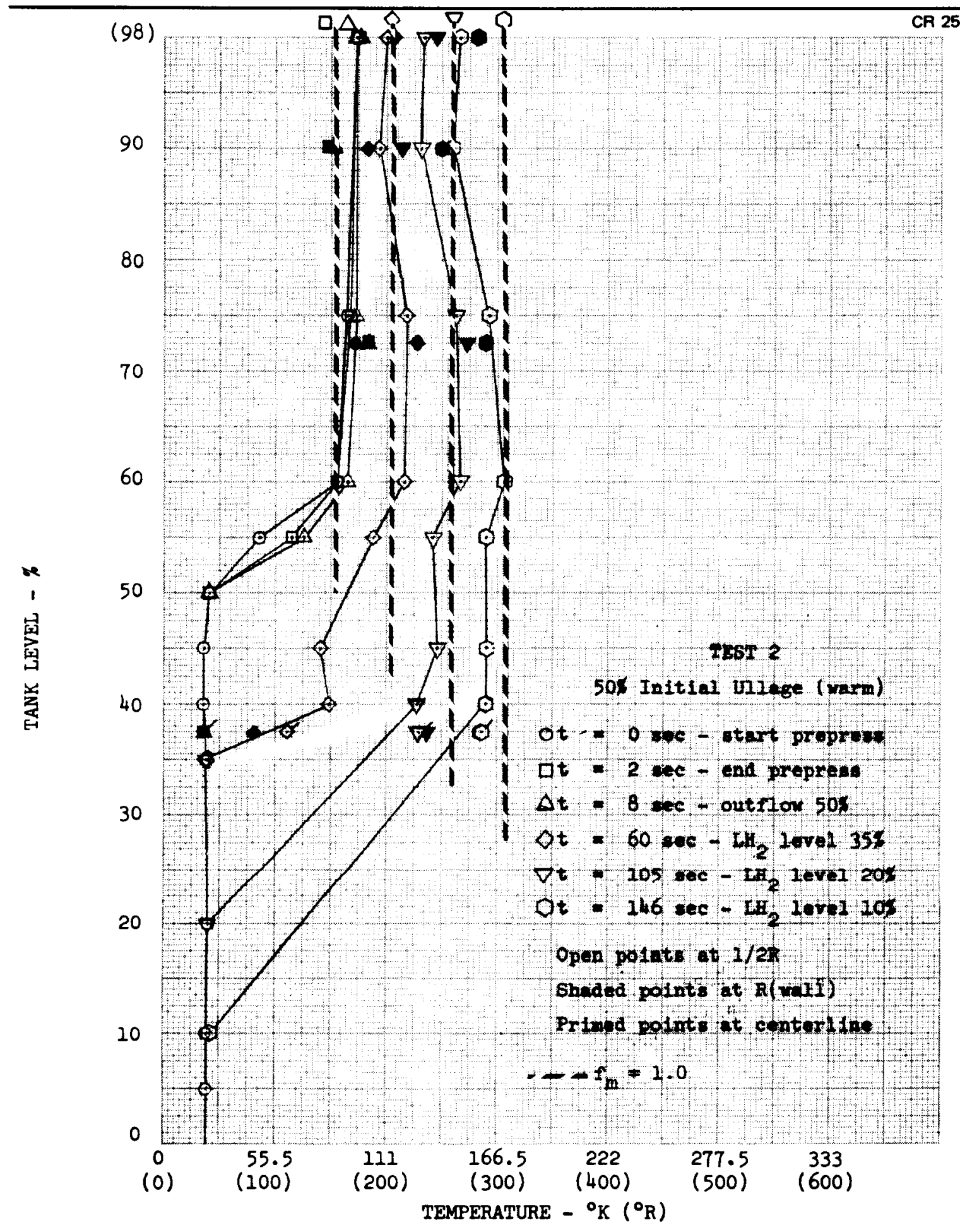

Figure 35. Temperature Correlation for Test 2, NAS3-14381 
predict the $\mathrm{GF}_{2}$ usage. In the previous tests under Contract NAS3-13306, the heat flux data were quite limited since a number of fluxmeters succumbed to the high ullage temperatures. In this program, since the ullage temperatures were much lower, consistent heat flux data were obtained for all tests. The heat flux data from these tests indicate heat transfer substantially in excess of that accounted for by free convection. The difference between the measured heat transfer coefficient and the free convection heat transfer coefficient was assumed to be the forced convection heat transfer coefficient. From Reference 10, the equation for forced convection to a vertical flat plate is:

$$
\frac{h_{f_{o}} d}{K}=0.037\left(\frac{\rho U d}{\mu}\right)^{4 / 5}\left(\frac{C_{p^{\mu}}}{K}\right)^{1 / 3}
$$

The forced convection heat transfer coefficient is weakly dependent on a characteristic dimension $\left(\mathrm{d}^{-1 / 5}\right)$ which was arbitrarily set at $0.1017 \mathrm{~m}$ (4 in.), the width and height of the fluxmeter. The velocity needed to give the correct forced convection coefficient was determined. In the previous tests it was observed that this velocity was related to the $\mathrm{GH}_{2}$ velocity in the injector and to the injector on-time fraction for the fluxmeters in the mixed zone (top of the ullage), by the correlation.

$$
\mathrm{U}_{\text {fo }}=.12 \mathrm{U}_{\mathrm{Jo}} \cdot \mathrm{f}
$$

In the previous tests, the injectant velocity, $U_{J_{0}}$, generally ranged from 6.1 to $9.1 \mathrm{~m} / \mathrm{sec}(20$ to $30 \mathrm{ft} / \mathrm{sec})$ and the on-time fraction was generally quite large (>0.5), except for the small ullage tests. The correlation was conveniently mechanized in the H819 computer code by setting $U_{\text {fo }}$ to equal 12 percent of the injectant velocity, and allowing forced convection to occur only during injection (which accounted 
for the $f$ dependence) even though it was apparent that forced convection heat transfer was occurring to some degree when injection was not occurring. For the tests where forced convection heat transfer was significant in predicting $\mathrm{GF}_{2}$ usage, the on-time fraction was usually near 1.0 , so that the computer mechanization of the correlation was in line with physical reality, and gave accurate results.

For the tests in this program, U Jo ranged from 61 to $70 \mathrm{~m} / \mathrm{sec}(200$ to $230 \mathrm{ft} / \mathrm{sec}$ ) and the on-time fractions were always very small $(<0.25)$. If the previous correlation and mechanization were used, the predicted heat transfer and $G_{2}$ usage were much smaller than observed. The reason, of course, was that forced convection heat transfer actually occurred for periods of time much longer than the on-time (as shown by the fluxmeter data). If the correlation was modified to give the observed heat transfer during injector cycling, the forced-convection velocity was unrealistically large (essentially equal to or greater than injection velocity), which caused problems of excessive heat transfer during relatively long prepressurizations.

It was determined that a different mechanization for the heat transfer process, more in line with physical reality, would be necessary to give the correct correlation of heat transfer data obtained in both the previous and current test programs. The forced convection heat transfer was assumed to occur all of the time (as indicated by the data) with an equivalent forced convection velocity equal to 6 percent of the injectant velocity, as shown in Figure 36. Again, forced convection is assumed to occur only in the mixed zone; in the lower unmixed portion of the ullage, the overall heat transfer coefficient was that for free convection only. 


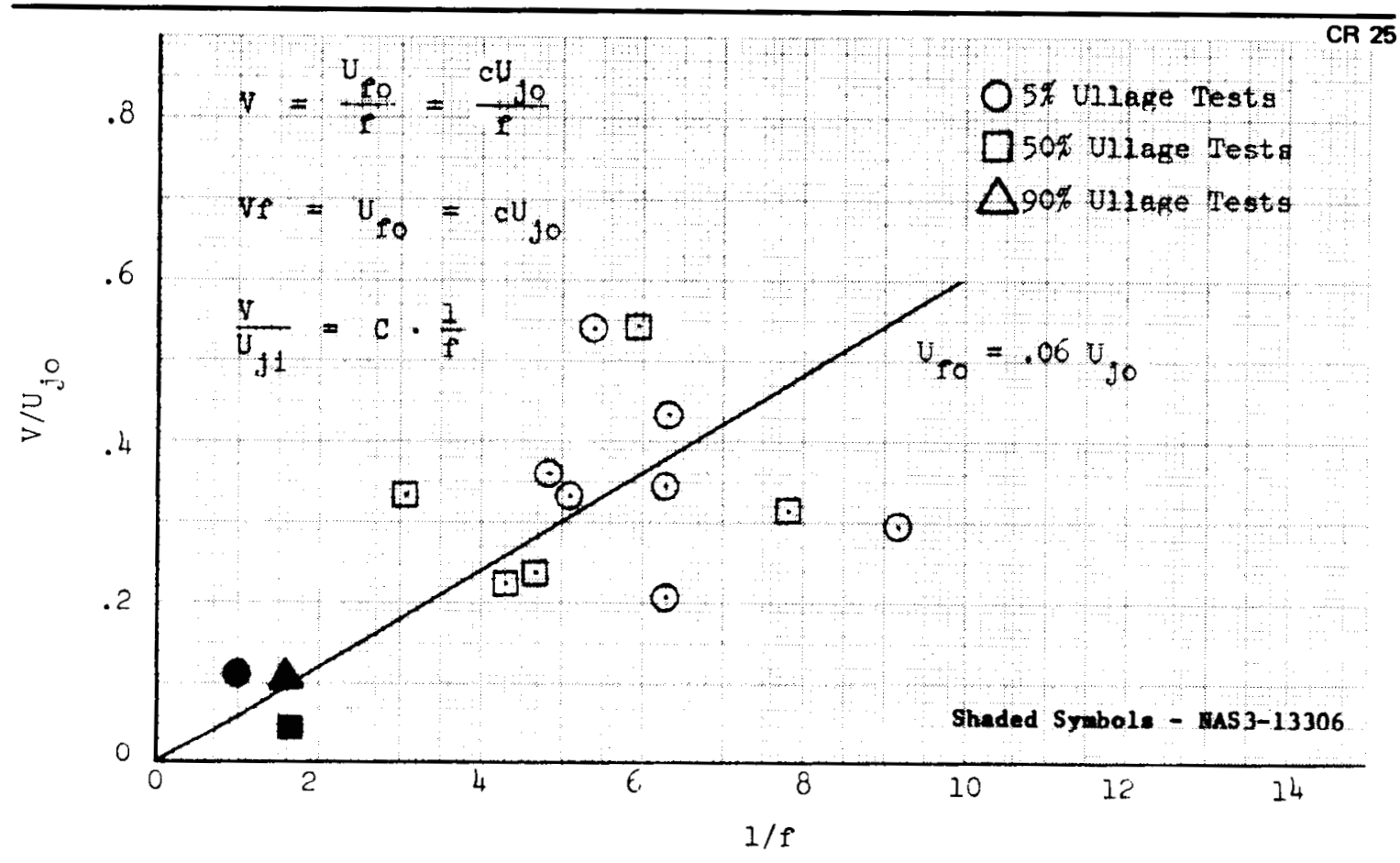

Figure 36. Forced Convection Heat Transfer Velocity Correlation

The jet penetration and heat transfer models gave good agreement between predicted and measured $\mathrm{GF}_{2}$ usage as shown in Table 7 , despite the scatter in the computed velocity data shown in Figure 36.

In order to ensure that the new heat transfer mechanization did not have adverse effects on the correlation of the previous straight-pipe tests from NAS3-13306, representative tests we re correlated using the current heat transfer model, as shown in Figure 37 for Test 2 (NAS3-13306), a high-pressure 50-percent ullage case, and in Figure 38 for Test 14 (NAS3-13306), a low-pressure 50 percent ullage case. Again, the agreement between prediction and experiment is excellent (especially for Test 2). A comparison of the $\mathrm{GF}_{2}$ usage predictions, both current and previous, with the observed $\mathrm{GF}_{2}$ usage is shown in Table 8 . 
Table 7

COMPARISON OF OBSERVED AND PREDICTED

CUMULATIVE $\mathrm{GF}_{2}$ USAGE

\begin{tabular}{|c|c|c|c|c|c|c|}
\hline \multirow[b]{2}{*}{ Test } & \multirow[b]{2}{*}{ Time } & \multicolumn{2}{|c|}{ Observed $\mathrm{GF}_{2}$ Usage } & \multicolumn{2}{|c|}{ Predicted $\mathrm{GF}_{2}$ Usage } & \multirow{2}{*}{$\frac{\text { Error }}{(\%)}$} \\
\hline & & $(\mathrm{kg})$ & (lb) & (kg) & (lb) & \\
\hline \multirow[t]{4}{*}{1} & 4 & 0.097 & 0.215 & 0.108 & 0.239 & +11.2 \\
\hline & 51 & 0.429 & 0.942 & 0.488 & 1.075 & +14.1 \\
\hline & 99 & 0.714 & 1. 572 & 0.762 & 1. 680 & +6.9 \\
\hline & 146 & 1.088 & 2.396 & 1. 109 & 2. 441 & +1.9 \\
\hline \multirow[t]{5}{*}{2} & 2 & 0.070 & 0.155 & 0.063 & 0.140 & -9.7 \\
\hline & 8 & 0.070 & 0.155 & 0.087 & 0.192 & +23.9 \\
\hline & 60 & 0.511 & 1. 124 & 0.557 & 1. 228 & +9.3 \\
\hline & 105 & 0.906 & 1. 996 & 1. 182 & 2. 606 & +30.6 \\
\hline & 146 & 1. 390 & 3.061 & 1. 804 & 3.980 & +30.3 \\
\hline \multirow[t]{5}{*}{3} & 10 & 0.253 & 0.557 & 0.255 & 0.562 & +0.9 \\
\hline & 101 & 0.340 & 0.749 & 0.255 & 0.562 & +25.0 \\
\hline & 151 & 0.700 & 1.542 & 0.548 & 1. 208 & -21.6 \\
\hline & 194 & 1.038 & 2. 285 & 1.033 & 2. 280 & -0.2 \\
\hline & 221 & 1. 540 & 3.390 & I. 470 & 3.243 & -4.3 \\
\hline \multirow[t]{5}{*}{4} & 4 & 0.098 & 0.216 & 0.114 & 0.251 & +16.2 \\
\hline & 7 & 0.098 & 0.216 & 0.132 & 0.291 & +34.7 \\
\hline & 67 & 0.651 & 1. 436 & 0.468 & 1.031 & -28.2 \\
\hline & 112 & 0.940 & 2.071 & 0.746 & 1. 645 & -20.6 \\
\hline & 160 & 1. 273 & 2.803 & 1. 110 & 2. 444 & -12.8 \\
\hline
\end{tabular}


Table 7 (Continued)

\begin{tabular}{|c|c|c|c|c|c|c|}
\hline \multirow[b]{2}{*}{ Test } & \multirow[b]{2}{*}{ Time } & \multicolumn{2}{|c|}{ Observed $\mathrm{GF}_{2}$ Usage } & \multicolumn{2}{|c|}{ Predicted $\mathrm{GF}_{2}$ Usage } & \multirow{2}{*}{$\frac{\text { Error }}{(\%)}$} \\
\hline & & $(\mathrm{kg})$ & (Ib) & $(\mathrm{kg})$ & (lb) & \\
\hline & 209 & 1. 518 & 3.340 & $(1.332)$ & $(2.941)$ & -11.9 \\
\hline & 265 & 1.805 & 3.975 & $*$ & $*$ & * \\
\hline & 317 & 1. 805 & 3.975 & $*$ & * & $*$ \\
\hline \multirow[t]{8}{*}{5} & 3 & 0.043 & 0.095 & 0.027 & 0.059 & -37.9 \\
\hline & 73 & 0.043 & 0.095 & 0.027 & 0.059 & -37.9 \\
\hline & 192 & 0.174 & 0.383 & 0.244 & 0.495 & +29.2 \\
\hline & 321 & 0.348 & 0.767 & 0.463 & 1.020 & +33.0 \\
\hline & 449 & 0.632 & 1. 392 & 0.701 & 1. 544 & +10.9 \\
\hline & 585 & 0.959 & 2. 112 & 0.991 & 2. 182 & +3.3 \\
\hline & 709 & 1. 286 & 2. 832 & 1. 490 & 3.286 & +16.0 \\
\hline & 797 & 1.612 & 3.552 & 2.000 & 4. 410 & +19.5 \\
\hline \multirow[t]{5}{*}{6} & 9 & 0.137 & 0.301 & 0.120 & 0.265 & -12.0 \\
\hline & 34 & 0.159 & 0.350 & 0.120 & 0.265 & -24.3 \\
\hline & 170 & 0.361 & 0.795 & 0.296 & 0.654 & -17.7 \\
\hline & 287 & 0.653 & 1. 438 & 0.607 & 1. 337 & -7.0 \\
\hline & 393 & 0.980 & 2. 179 & 0.929 & 2.046 & -6.1 \\
\hline \multirow[t]{2}{*}{7} & 18 & 0.276 & 0.607 & 0.287 & 0.633 & +4.1 \\
\hline & 113 & 0.298 & 0.657 & 0.350 & 0.749 & +14.0 \\
\hline
\end{tabular}

* Correlation not completed for interrupted test. 


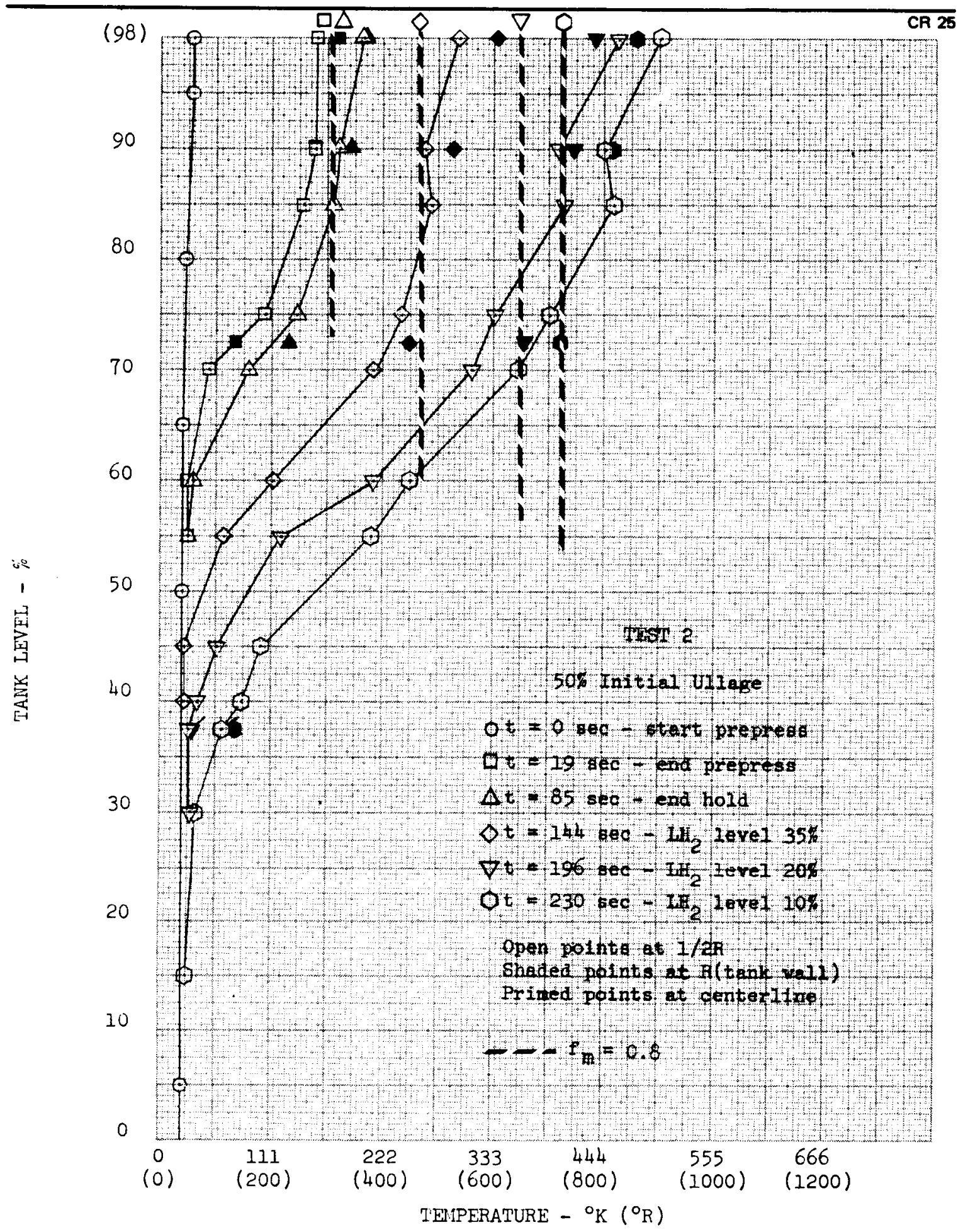

Figure 37. Temperature Correlation for Test 2, NAS3-13306, Straight-Pipe 


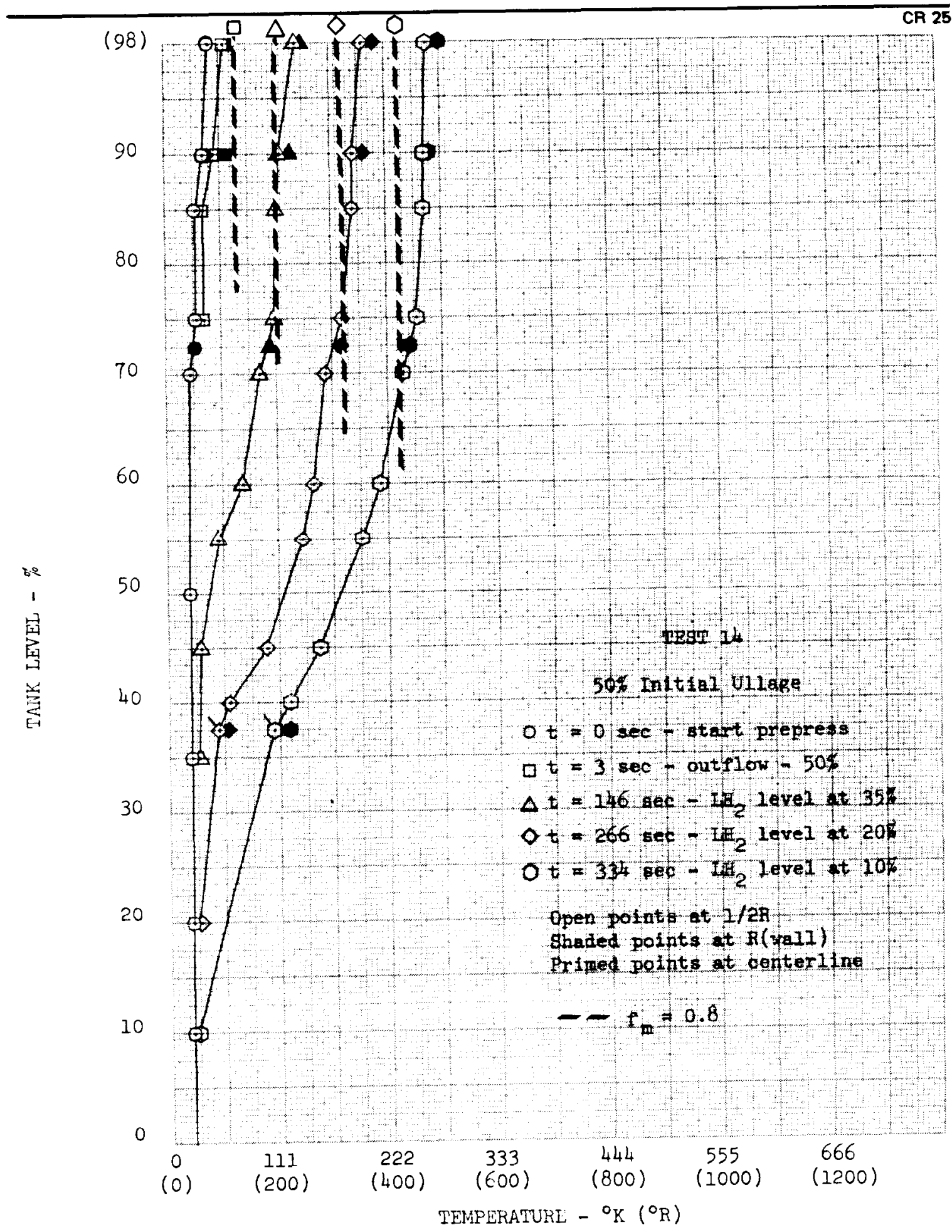

Figure 38. Temperature Correlation for Test 14, NAS3-13306, Straight-Pipe 


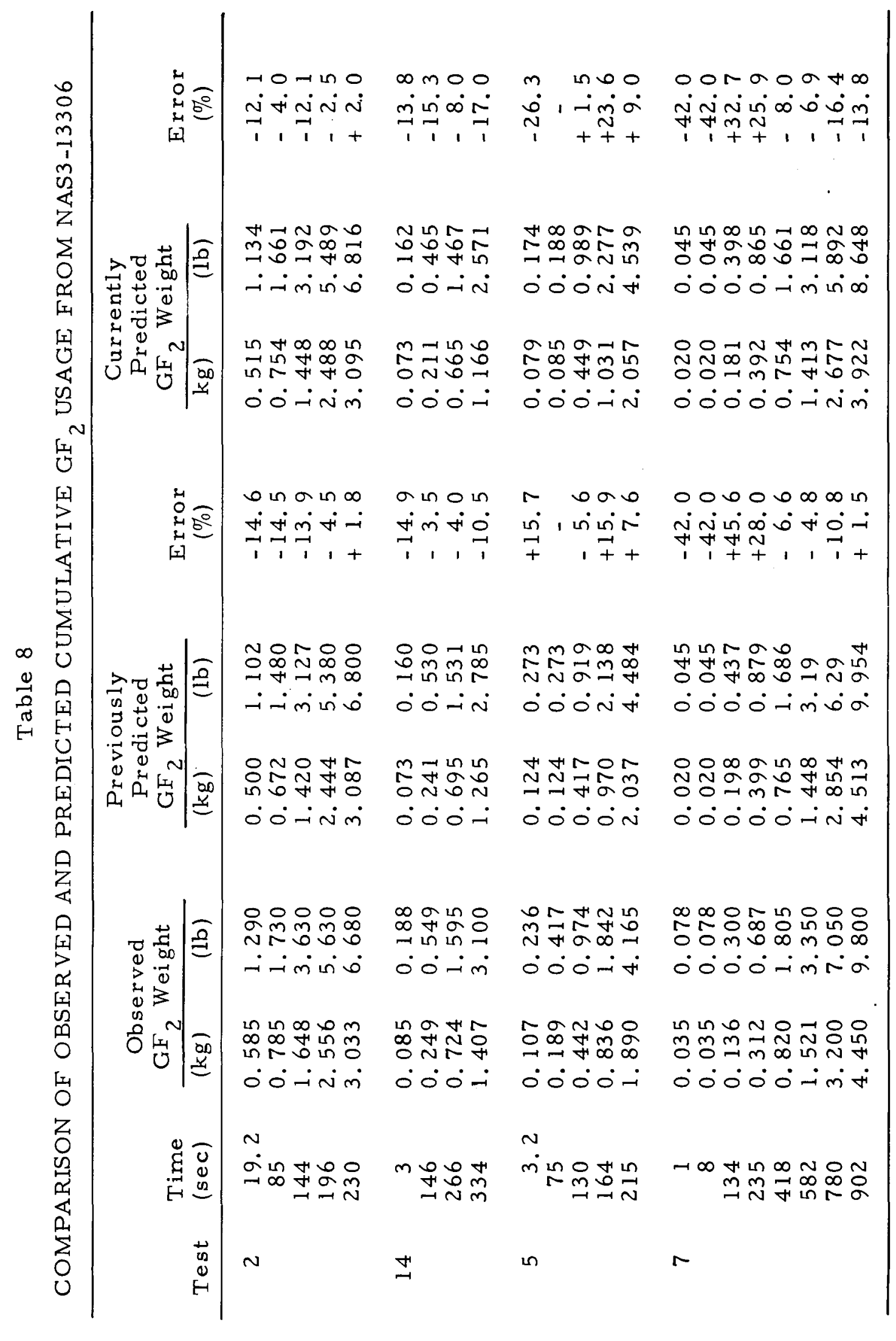


Following the successful correlation of the large-ullage tests (which verify the jet penetration and heat transfer models), the small-ullage tests were analyzed. In order to accurately predict ullage temperature history, $\mathrm{GF}_{2}$ usage, and $\mathrm{LH}_{2}$ evaporation, the $\mathrm{LH}_{2}$ interface mass and heat transfer processes must be accurately modeled.

The correlation established in the previous investigation (NAS3-13306, see Reference 2) for interface heat and mass transfer was expressed by

$$
\begin{aligned}
& \dot{\mathrm{q}}_{\mathrm{g}}=0.6 \mathrm{x}_{\mathrm{L}}^{2} \\
& \dot{\mathrm{q}}_{\mathrm{L}}=0.2 \mathrm{q}_{\mathrm{g}}
\end{aligned}
$$

for the gas-to-interface and interface-to-liquid heat transfer rates, respectively. The difference $\dot{q}_{g}-\dot{q}_{L}$ is the heat input rate to liquid vaporization. These same equations were retained initially in the 5-percent ullage computations for the jet pump injector tests, but gave much less vaporization than indicated by the mass balance. The initial liquid penetration depth, $X_{L}$, with the NAR injector was similar to that with the straight-pipe injector, although the injector-to-liquid distance was more than three times as great with the jet pump. It is apparent that the injector-to-liquid distance is an important parameter in determining the heat transfer and evaporation rates. The total heat rate was assumed proportional to the a rea of the jet impingement (proportional to the square of the injector-to-liquid distance) as well as the intensity of the convective disturbance (proportional 
to the square of the penetration depth). The resulting correlation of this form is

$$
\dot{\mathrm{q}}_{\mathrm{g}}=0.15\left(\mathrm{x}_{\mathrm{if}}-\mathrm{x}_{\mathrm{in}}\right)^{2} \mathrm{x}_{\mathrm{L}}^{2}
$$

where the coefficient value of 0.15 was determined from the NAR injector test data. This correlation is effective for reasonably large injector-to-liquid distances. However, the heat transfer rate approaches zero as the injector exit approaches the interface (as $\left[\mathrm{X}_{\text {if }}-\mathrm{X}_{\mathrm{in}}\right]$ approaches zero). This is not physically valid; therefore, a minimum value of $\left(X_{\text {if }}-X_{\text {in }}\right)=0.3048 \mathrm{~m}(1.0 \mathrm{ft})$ is maintained in the computer code for this relationship. Of the total heat transferred from the gas, 20 percent is lost to liquid heating and 80 percent vaporizes liquid as in the previous correlation.

With this interface model, the ullage gas temperatures were predicted accurately for Tests 1 and 4 as shown in Figures 39 and 40 . The GF 2 usage for these tests was also accurately predicted, as shown in Table 7. (The correlation was not pursued to the end of Test 4 because the $G_{2}$ injection was shut down at $t=187$ seconds, restarted, and again shut down at indeterminate ullage volumes.) When compared to representative 5 percent ullage tests from NAS3-13306 (Tests 4 and 5) the new correlation gave conservative temperature prediction (the least accurate match is shown in Figure 41 for Test 5 ) at the previously assumed $\mathrm{f}_{\mathrm{m}}=0.8$.

The correlation was not successful for Test 5, which was a low pressure, low $\mathrm{LH}_{2}$ outflow rate, long duration ( 800 seconds) test. In the previous program under Contract NAS3-13306, Test 7 was the same kind of test and also was not correlated by Equation (23). The reason advanced at that time was that the long duration of the test allowed external heat leak to cause a layer of saturated $\mathrm{LH}_{2}$ to build 


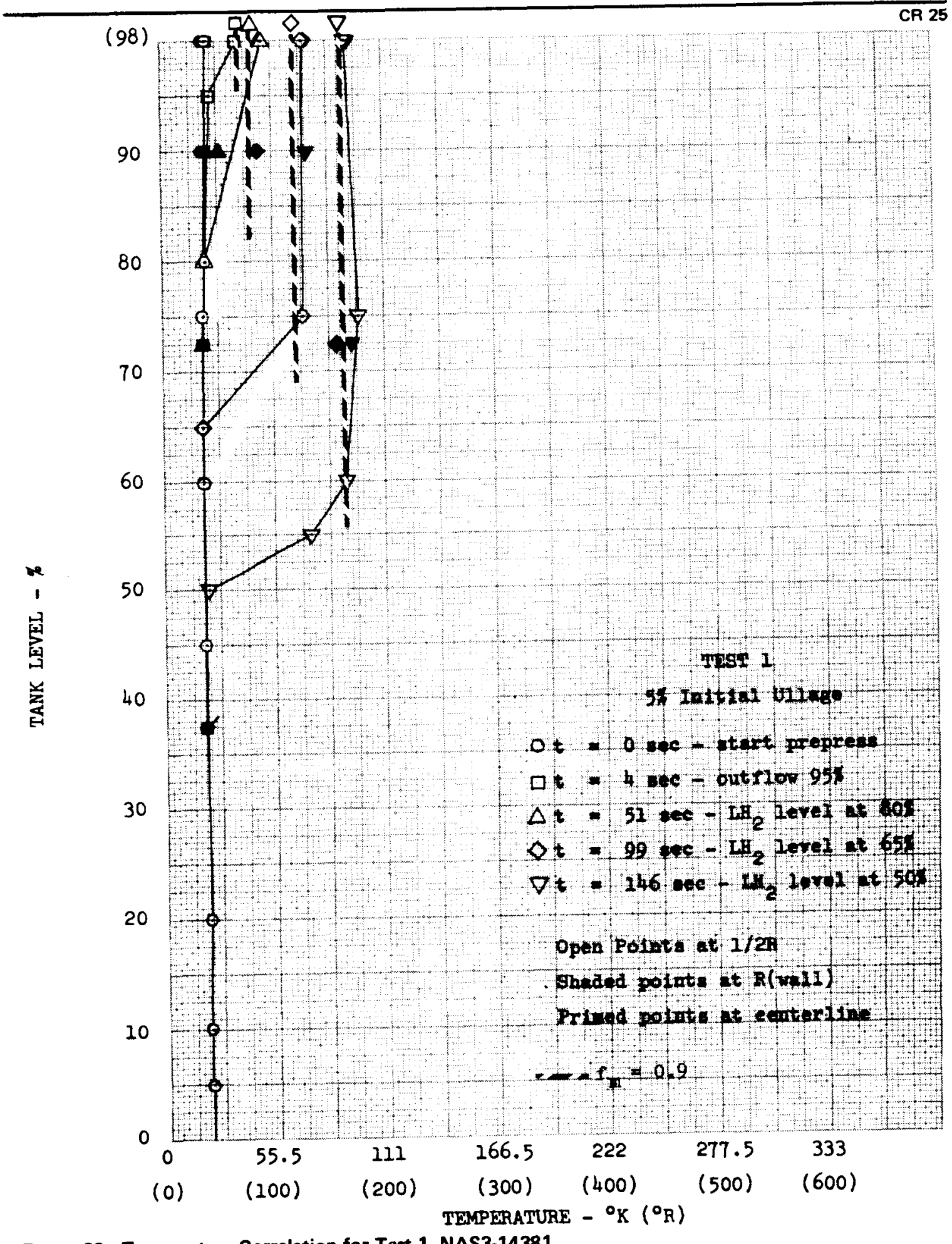

Figure 39. Temperature Correlation for Test 1, NAS3-14381 


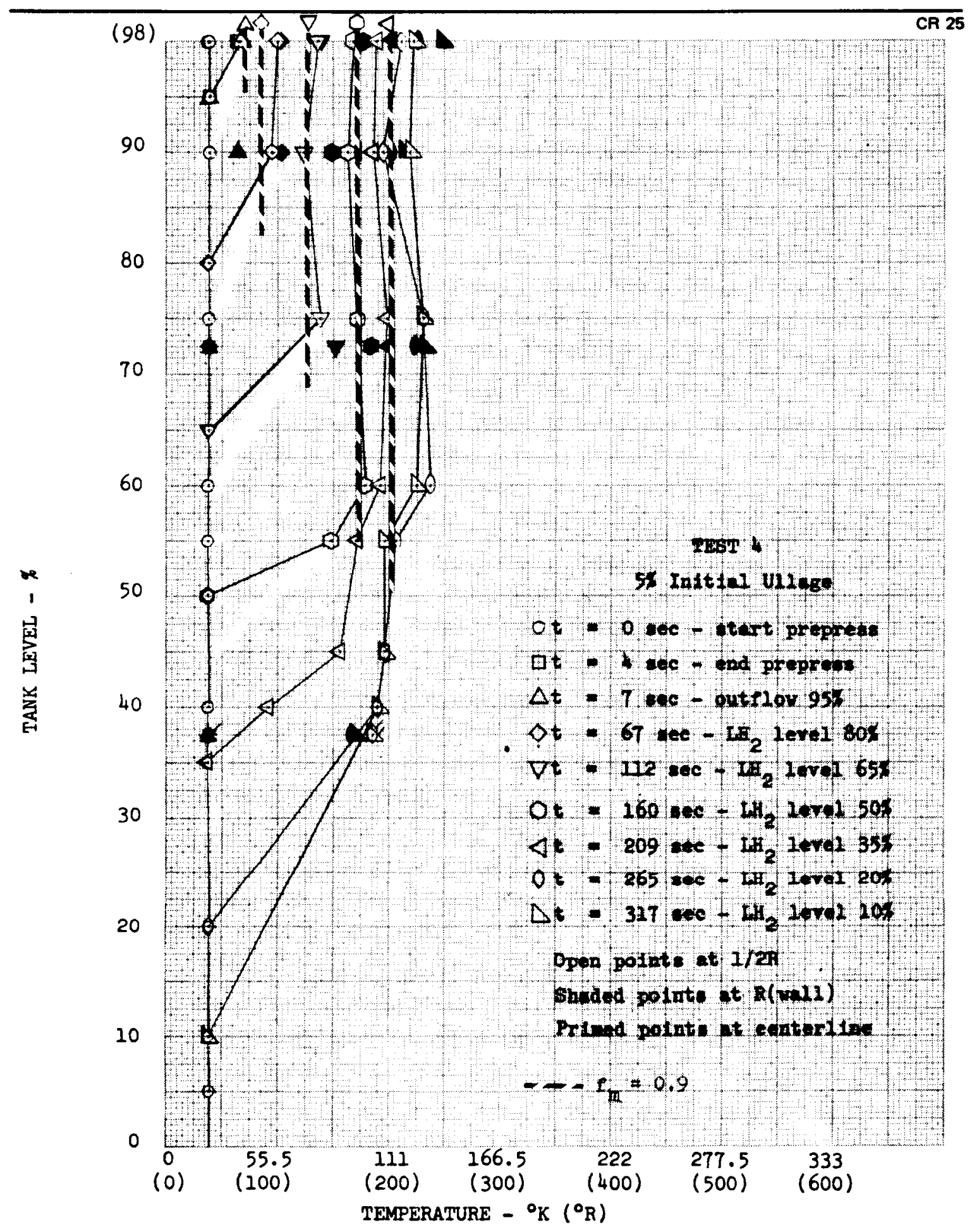

Figure 40. Temperature Correlation for Test 4, NAS3-14381 


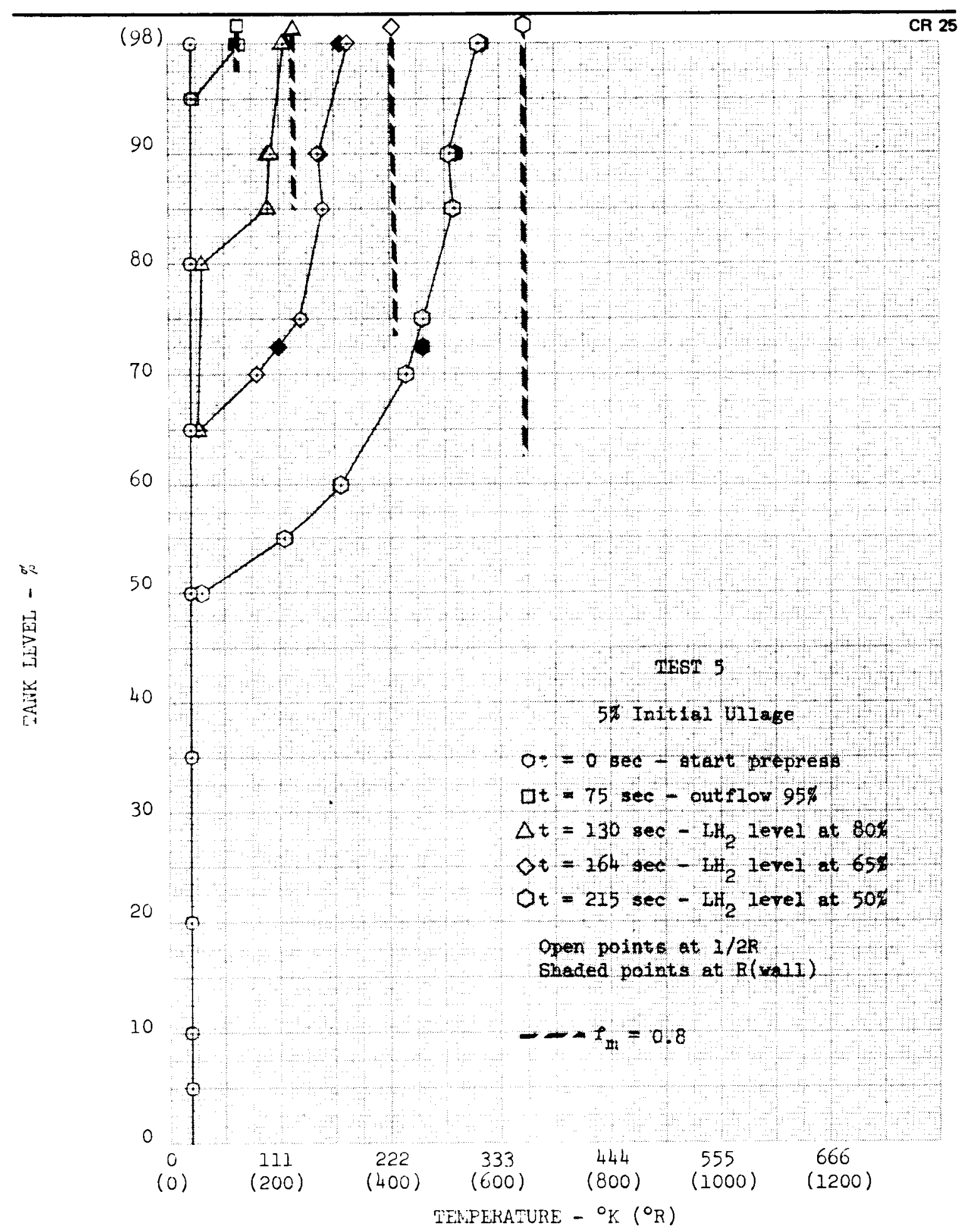

Figure 41. Temperature Correlation for Test 5, NAS3-13306, StraightPipe 
up at the interface, so that all heat input went to evaporation. Further, it was postulated that the evaporation would not necessarily depend on $X_{L}$ because of the very short on-time fraction and very transient $\mathrm{LH}_{2}$ penetration. It was assumed that evaporation would only depend on the available energy in the ullage, or simply as a fraction of $\mathrm{q}_{\mathrm{C}}$ : Thus,

$$
\begin{aligned}
& \dot{\mathrm{q}}_{\mathrm{g}}=0.25 \mathrm{q}_{\mathrm{c}} \\
& \dot{\mathrm{q}}_{\mathrm{L}}=0
\end{aligned}
$$

was the assumed correlation which, together with $\mathrm{f}_{\mathrm{m}}=0.9$, gave good agreement with temperature history, $\mathrm{GF}_{2}$ usage, and evaporation for Test 7, as described in Reference 2. Because of the similarity of Test 5 from this program to the previous Test 7 , the same correlation was used, together with $\mathrm{f}_{\mathrm{m}}=1.0$ and the NAR injector model. This gave fair agreement, and conservatively predicted the temperature history, as shown in Figure 42. However, the $\mathrm{GF}_{2}$ usage prediction was high by 38 percent-2. $22 \mathrm{~kg}$ (4. $898 \mathrm{lb})$ compared to the observed $1.612 \mathrm{~kg}(3.552 \mathrm{lb})$. The data in Figure 42 indicated that the flow characteristics of the injector were changing during the test-note that the prediction first leads, then lags, then again leads the data. It was thought that while the injector was being damaged by overheating, it operated at a slightly different $O / F$ ratio and equilibrium temperature. Assuming an $O / F$ ratio of 30 and $T_{J}$ equal to $1,390^{\circ} \mathrm{K}\left(2,500^{\circ} \mathrm{R}\right)$ gave good final temperature correlation, as shown in Figure 43 , but the $\mathrm{GF}_{2}$ usage was still predicted too high (see Table 7) and unexplained anomalies still existed during the test (for $t=192,321,499$, and 585 seconds).

Again Test 7 from NAS3-13306 was analyzed with the new heat transfer mechanization, and with the Equation (25) interface model, and gave excellent correlation, as shown in Figure 44. The GF usage comparisons, current and previous, are shown in Table 8. 


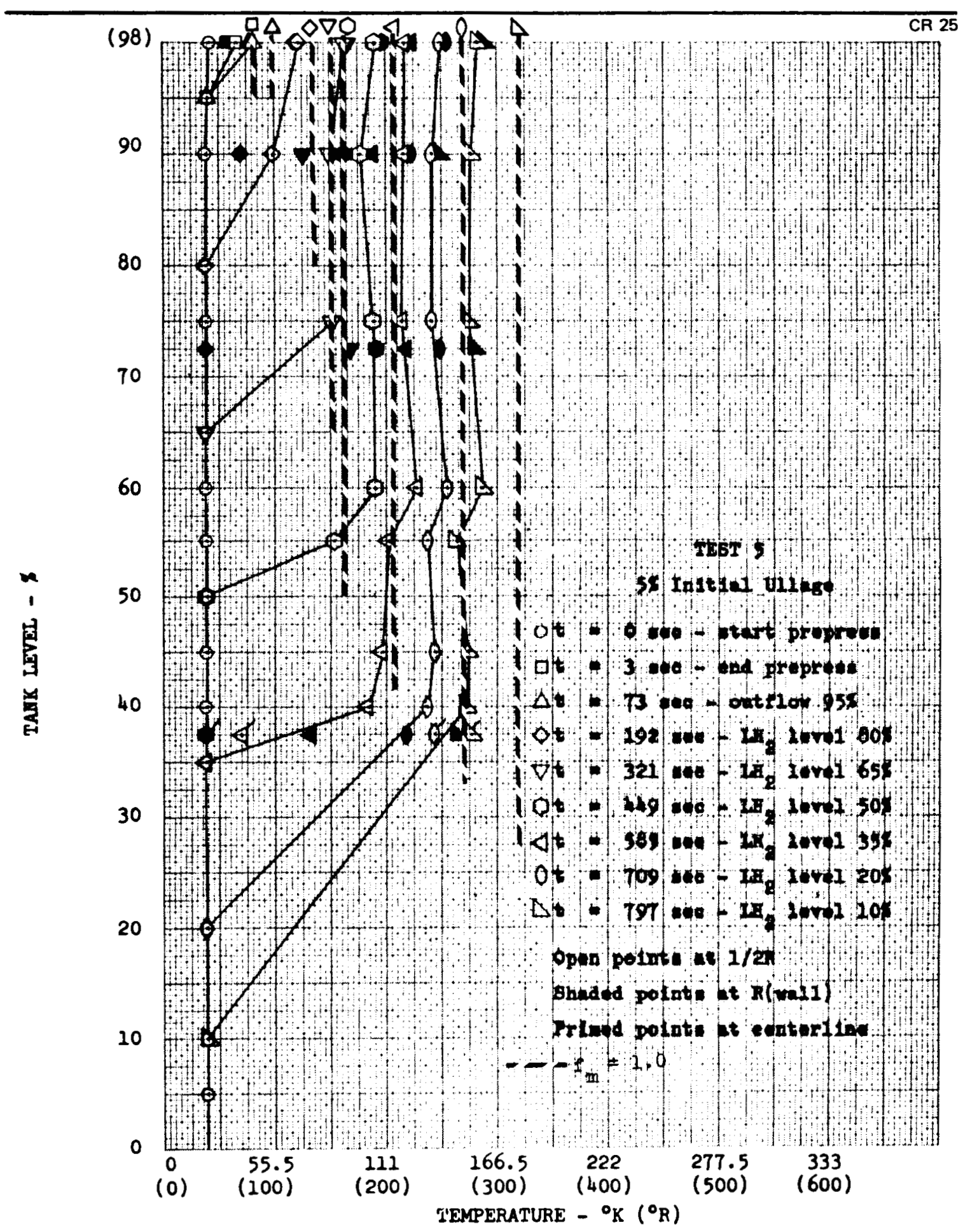

Figure 42. Temperature Correlation for Test 5, NAS3-14381 


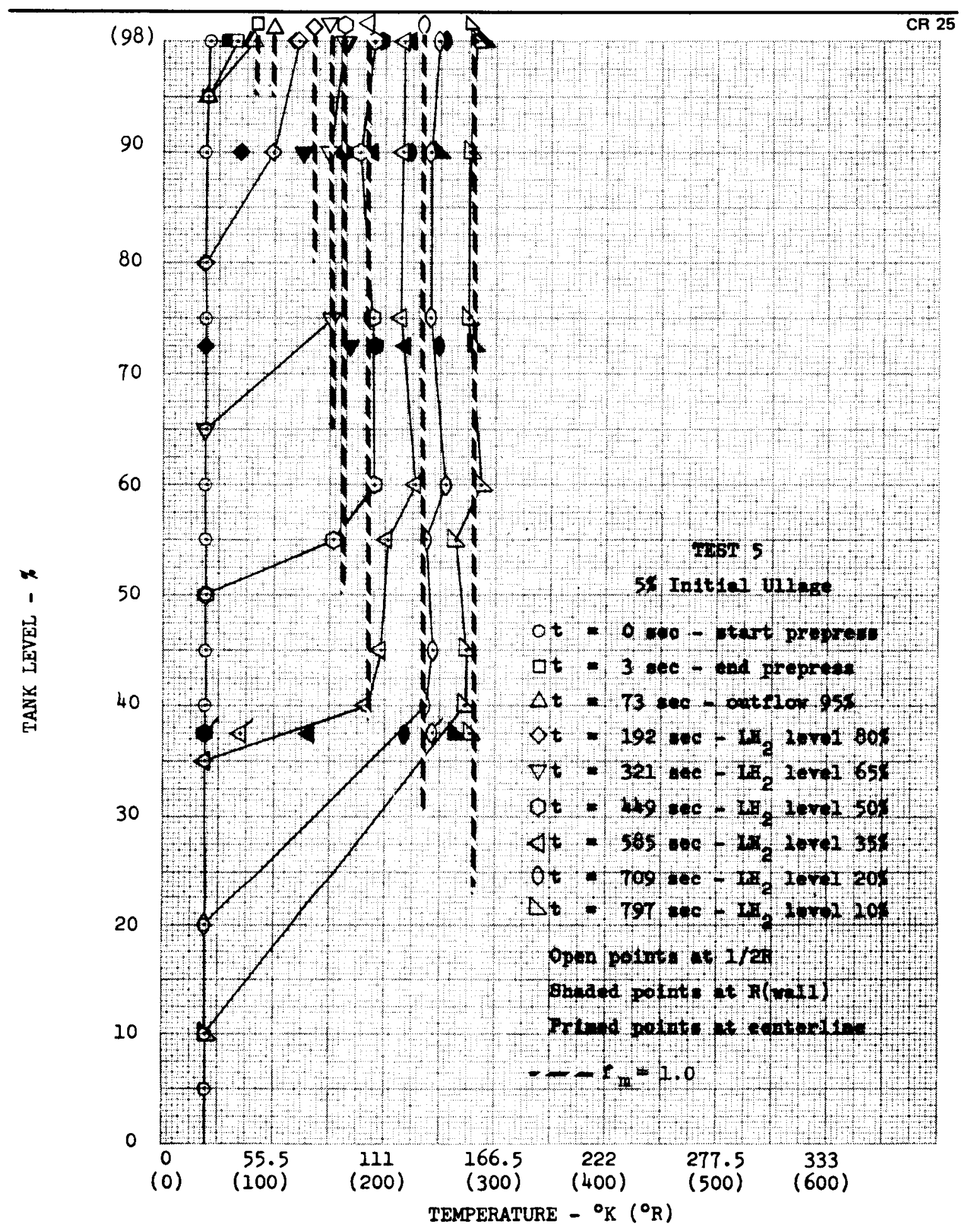

Figure 43. Temperature Correlation for Test $5, N A S 3-14381,\left(O / F=30, T_{j}=1390^{\circ} \mathrm{K}\left(2500^{\circ} \mathrm{R}\right)\right)$ 


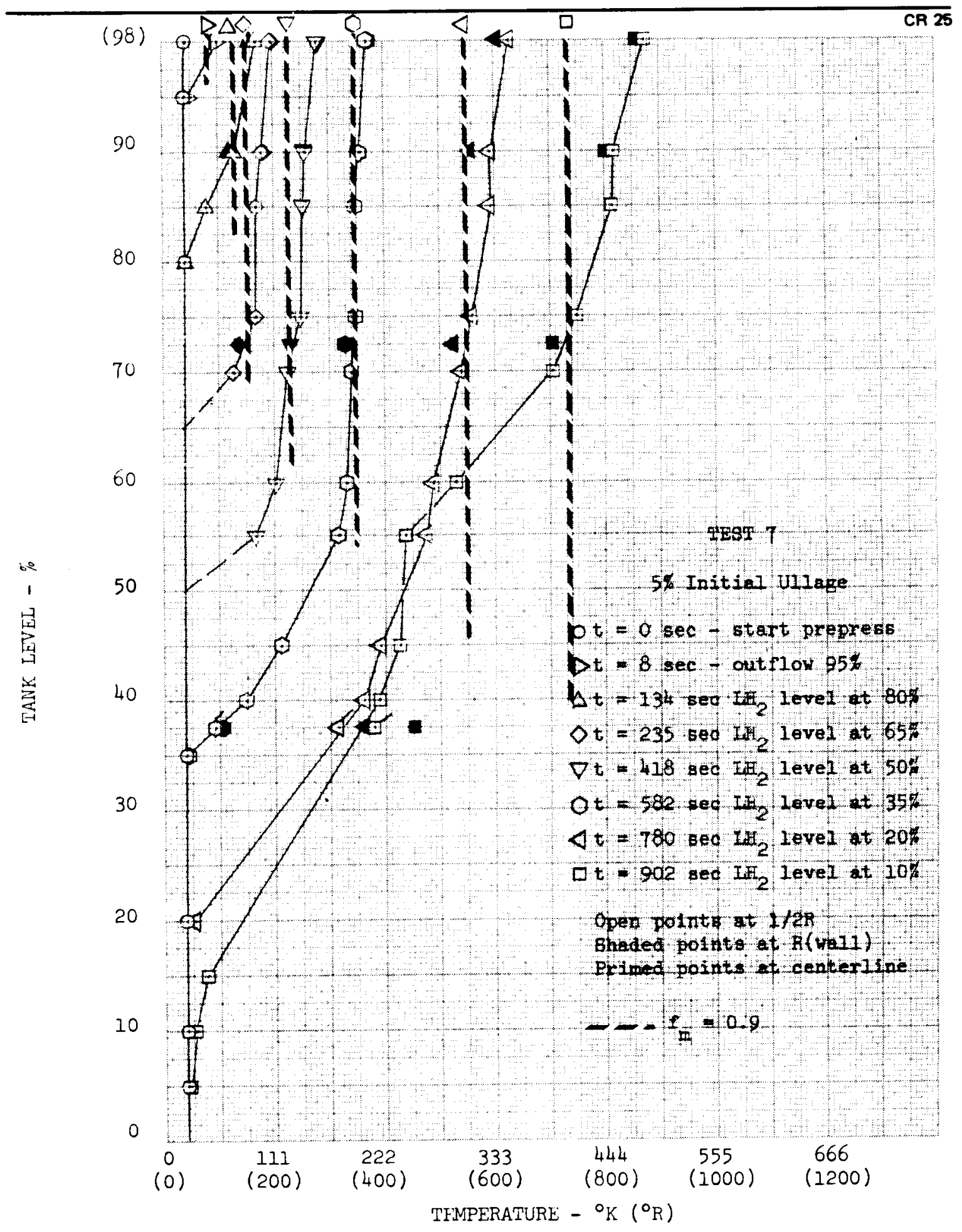

Figure 44. Temperature Correlation for Test 7, NAS3-13306, Straight-Pipe 
The evaporated mass was also determined and is discussed in the next subsection.

\section{Ullage Gas Mass and Tank Enthalpy Balance}

An ullage mass balance and ullage gas and tank wall enthalpy balance was computed for each test. The ullage mass was calculated from the measured pressure and local temperature conditions measured at the sensor locations; the temperature was assumed to vary linearly between the measured points. When conditions in the ullage changed slowly, the temperature sensors were able to respond adequately, and the mass balance gave reasonable results. However, when the ullage temperatures changed rapidly, as during large ullage prepressurization, the response lag of the platinum temperature sensors gave erroneous results for the mass balance. Under these conditions, the ullage was actually warmer than the sensors were recording, so that the mass computed from the "colder" temperatures was larger than the actual mass. This effect also occasionally occurred due to temperature extrapolation caused by missing sensors, especially near the $\mathrm{LH}_{2}$ interface. However, for the large ullage tests, the ullage mass stayed constant within 8 percent or less, which confirmed that ullage mass addition did not occur, as was predicted by the analysis.

The mass balances for the small ullage cases gave generally good results because of slower changes in temperature. These are shown in Table 9 and compared with the predicted evaporation.

As was the case for the tests under Contract NAS3-13306, the enthalpy balances were rather imprecise, because of temperature sensor lag and the requirement for linear interpolation between a relatively few wall temperature sensors. 
Table 9

MASS BALANCES, 5-PERCENT ULIAAGE

\begin{tabular}{|c|c|c|c|c|c|}
\hline \multirow[b]{2}{*}{ Test } & \multirow[b]{2}{*}{ Time } & \multicolumn{2}{|c|}{$\begin{array}{l}\text { Ullage Mass Computed } \\
\text { From Temperature Data }\end{array}$} & \multicolumn{2}{|c|}{$\begin{array}{l}\text { Predicted } \\
\text { Ullage Mass }\end{array}$} \\
\hline & & $(\mathrm{kg})$ & (lb) & $(\mathrm{kg})$ & (lb) \\
\hline \multirow[t]{5}{*}{1} & 0 & 2.55 & 5.627 & 2. 55 & 5.627 \\
\hline & 4 & 4.55 & 10.013 & 4.92 & 10.834 \\
\hline & 51 & 12.55 & 27.650 & 11.79 & 25.990 \\
\hline & 99 & 12.30 & 27.061 & 12. 72 & 28.040 \\
\hline & 146 & 11.97 & 26.378 & 12.84 & 28.344 \\
\hline \multirow[t]{9}{*}{4} & 0 & 2.42 & 5.336 & 2.42 & 5.336 \\
\hline & 4 & 4.63 & 10.198 & 5.05 & 11.135 \\
\hline & 7 & 4.28 & 9.422 & 5.51 & 12.139 \\
\hline & 67 & 9.25 & 20.408 & 11.12 & 24.558 \\
\hline & 112 & 11.00 & 24.229 & 12. 10 & 26.666 \\
\hline & 160 & 11.10 & 24.449 & 12.25 & 26.980 \\
\hline & 209 & 11.60 & 25.586 & 12.25 & 27.001 \\
\hline & 265 & $(13.46)$ & $(29.668)$ & 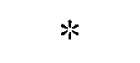 & $*$ \\
\hline & 317 & $(13.43)$ & $(29.593)$ & $*$ & $*$ \\
\hline \multirow[t]{9}{*}{5} & 0 & 2.60 & 5.724 & 2.60 & 5.724 \\
\hline & 3 & 3.19 & 7.024 & 2.80 & 6.186 \\
\hline & 73 & 2.78 & 6.126 & 2.80 & 6.186 \\
\hline & 192 & 6.09 & 13.410 & 4.35 & 9.577 \\
\hline & 321 & 6.74 & 14.852 & 6.20 & 13.662 \\
\hline & 449 & 7.09 & 15.609 & 8.05 & 17.738 \\
\hline & 585 & 7.80 & 17.171 & 8.96 & 19.768 \\
\hline & 709 & $(9.85)$ & $(21.680)$ & 8.96 & 19.768 \\
\hline & 797 & $(10.67)$ & $(23.533)$ & 8.96 & 19.768 \\
\hline
\end{tabular}

*Correlation not completed because of test interruption.

Parenthetical values based on linear interpolation due to missing temperature sensors. 
Table 10 shows the comparison between the predicted evaporation for Tests 5 and 7 from NAS3-13306 using the current and previous correlations. Note that the evaporation for Test 5 is somewhat under-predicted by the current correlation; this accounts for the increased temperature shown in Figure 41.

\section{ANALYSIS MODIFICATIONS}

The jet pump injector capability was added to the computer analysis by incorporating Equation (20) for the calculation of the jet-exit velocity. This velocity is a function of two new input quantities, the jet pump $\mathrm{O} / \mathrm{F}$ ratio and the average jet-exit temperature. The pumped hydrogen mass flow rate (determined by the $O / F$ ratio and the $G F_{2}$ flow rate) is removed from the bottom of the tank as liquid and added to the mixed ullage region. The conventional straight-pipe injector is used as before in the program when a zero is input for the $O / F$ ratio.

Additional pressure regulator options were added to the program as follows: 1) constant delivery pressure; 2) delivery pressure a specified multiple of the tank pressure; 3 ) delivery pressure specified by an input time-variable table; 4) option 3 switching to option 1 at the end of prepressurization; and 5) option 3 switching to option 2 at the end of prepressurization.

The revised relationship for the equivalent forced convection heat transfer velocity $U_{\text {fo }}$ is

$$
\mathrm{U}_{\mathrm{fo}}=.06 \mathrm{U}_{\mathrm{Jo}}
$$

During the $G F_{2}$ valve off-times, the last computed value of the forced convection heat transfer coefficient increment from the previous injector on-time is added to the calculated free-convection coefficient; 


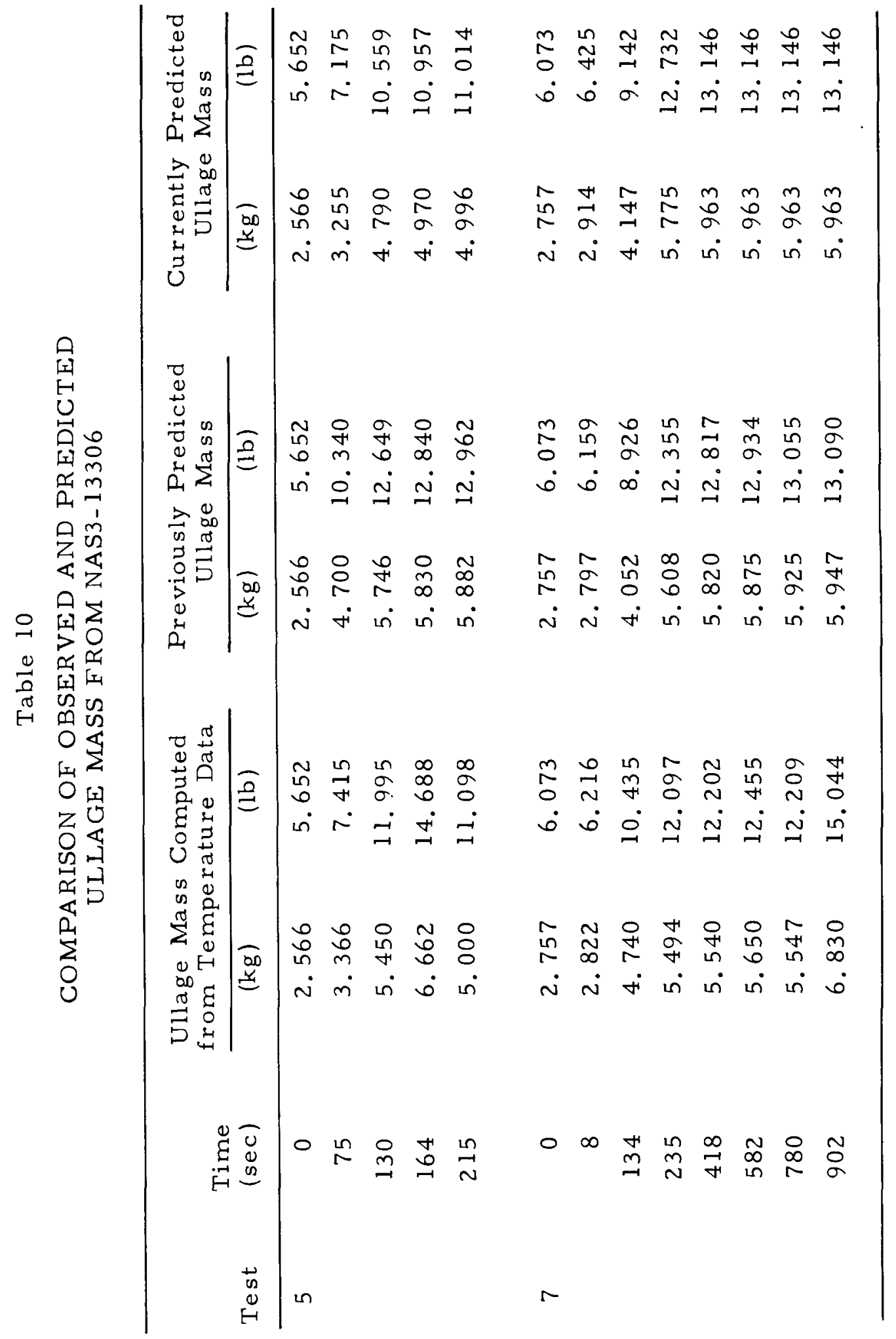


this is in contrast to the previous model which added forced convection only when the injector was flowing $G_{2}$. As previously, the forced convection heat transfer affects only the mixed ullage region. However, the mixed ullage region is retained during the injector off-time at the last computed value of the mixing depth from the previous injector ontime; this is in contrast to the previous model in which the subdivision of the entire ullage into nodes was permitted to occur during the injector off-times. The revised interface heat transfer relationship is given by Equation (24). This equation is used in the program in the same manner as the previous relationship [Equation (23)].

\section{MTI SYSTEM CONSIDERATIONS}

The first stage preheating and the second stage $\mathrm{H}_{2}$ aspiration which occurs with the NAR injector contribute to increased penetration, mixing, evaporation, and reduced ullage gas temperatures and $\mathrm{GF}_{2}$ consumption. However, the injector as designed to pump $\mathrm{LH}_{2}$ would require a regulator, a larger valve, and a vacuum-jacketed $\mathrm{LH}_{2}$ feed line. If the injector were redesigned to effectively aspirate $\mathrm{GH}_{2}$, the heavy vacuum-jacketed line could be eliminated, but the injector regulator and larger valve, if flight-weight, could add perhaps $3.2 \mathrm{~kg}(7.0 \mathrm{lb})$ to the system weight; at the same time, for complete expulsion in a $28.3-\mathrm{m}^{3}\left(1,000-\mathrm{ft}^{3}\right)$ tank, perhaps $3.2 \mathrm{~kg}$ (7. $0 \mathrm{lb}$ ) of $\mathrm{GF}_{2}$ would be saved, compared to the nonoptimized straight-pipe system tested under Contract NAS3-13306. In the previous program, an advanced Centaur vehicle MTI system was designed and analyzed. Because of the low g-field during pressurization, a diffuser-type injector was used, but excellent penetration, mixing, low $\mathrm{GF}_{2}$ usage, and cold ullage temperatures were obtained.

Injectant penetration is clearly the most important parameter in obtaining good MTI pressurization performance, and through suitable selection of injection characteristics, the MTI system can be designed to deliver whatever level of performance is desired. 


\section{CONCLUSIONS}

The conclusions from this comprehensive analytical and experimental program are as follows:

A. A unique jet-pump injector was designed and fabricated by North American Rockwell-Rocketdyne (NAR), and tested in the $28.3-\mathrm{m}^{3}\left(1,000-\mathrm{ft}^{3}\right)$ flight-weight $\mathrm{LH}_{2}$ test tank system used in Contract NAS3-13306. The MTI control and injection system was modified with the addition of a specially designed proportional $\mathrm{GF}_{2}$ pressure regulator, enlarged injector valve, and vacuum-jacketed injector $\mathrm{LH}_{2}$ feed line, and performed in a nominal fashion, controlling the tank pressure to within $0.69 \times 10^{4} \mathrm{~N} / \mathrm{m}^{2}$ (1.0 psia) under essentially all conditions.

B. The NAR injector was able to jet-pump $\mathrm{LH}_{2}$ only under steady-state conditions when completely chilled (with a full $\mathrm{LH}_{2}$ tank). During large ullage tests and during all cyclic operation of the MTI system, the injector pumped only $\mathrm{H}_{2}$ vapor, which resulted in damage to the $\mathrm{LH}_{2}$ pumping annulus from overheating.

C. The first stage preheating of the $\mathrm{GF}_{2}$ injectant, and $\mathrm{H}_{2}$ vapor pumping, resulted in increased jet penetration and ullage mixing for the NAR injector, which gave improved MTI pressurization performance (reduced ullage temperatures and $\mathrm{GF}_{2}$ consumption) compared to that of a nonoptimum straight-pipe injector tested under Contract NAS3-13306.

D. The MTI pressurization computer code, H819, was used successfully to correlate the data from the NAR injector tests with only minor modifications. 


\section{REFERENCES}

1. E. C. Cady. An Investigation of Fluorine-Hydrogen Main Tank Injection Pressurization. NASA CR-72408, (DAC-62233), April 1968.

2. E. C. Cady and D. W. Kendle. Vehicle-Scale Investigation of a Fluorine-Hydrogen Main Tank Injection Pressurization System. NASA CR-72756, (MDC G0805), July 1970.

3. H. E. Barber. Hydrogen Tank Pressurizing Gas Injector. NASA CR-72998, (R-8713), October 1971.

4. W. H. Roudebush. An Analysis of the Problem of Tank Pressurization During Outflow. NASA TN D-2585, January 1965.

5. Fortran Program for the Analysis of a Single-Propellant Tank Pressurization System. Rocketdyne Report S\&ID IDWA 5835, 15 June 1964.

6. D. W. Kendle. A Tank Pressurization Computer Program for Research Applications. DAC-63076, December 1968.

7. D. W. Kendle. Ullage Mixing Effects on Cryogenic Tank Pressurization. DAC-63168, March 1968.

8. J. Laufer. Turbulent Shear Flows of Variable Density. AIAA Journal, April 1969; Vol. 7, No. 4, P 706.

9. R. L. DeWitt, R. J. Stochl, and W. R. Johnson. Experimental Evaluation of Pressurant Gas Injectors During the Pressurized Discharge of Liquid Hydrogen. NASA TN D-3458, June 1966.

10. W. H. McAdams. Heat Transmission. McGraw-Hill Book Co., New York, 1954. 
Appendix

DISTRIBUTION LIST FOR FINAL REPORT, NASA CR-120947

\section{Recipient}

Designee

No.

Copies

National Aeronautics \& Space

Administration

Lewis Research Center

21000 Brookpark Road

Cleveland, Ohio 44135

Attn: Contracting Officer, MS 500-313

E. A. Bourke

MS 500-203

J. W. Gregory

500-203

Technology Utilization Office, MS 3-16

AFSC Liaison Office, 501-3

Library

Office of Reliability \& Quality

Assurance, MS 500-111

1

2

2

E. M. Krawczonek

MS 500-209

E. A. Edelman, Project Manager MS 501-6

R. J. Stochl, MS 500-204

R. L. Dewitt, MS 500-204

A. J. Stofan, MS 500-103

W. R. Dunbar, MS 500-106

Don A. Hart RPD

Office of Aeronautics \& Space

Technology

NASA Headquarters

Wa shington, D. C. 20546

Frank W. Stephenson, Jr. RPI

Office of Aeronautics \& Space

Technology

NASA Headquarters

Wa shington, D. C. 20546

Director, Launch Vehicles \&

Propulsion, SV

Office of Space Science \& Applications

NASA Headquarters

Washington, D. C. 20546 
Chief, Environmental Factors \&

Aerodynamics

Code RV-1

Office of Advanced Research \&

Technology

NASA Headquarters

Wa shington, D. C. 20546

Chief, Space Vehicles Structures

Office of Advanced Research \&

Technology

NASA Headquarters

Wa shington, D. C. 20546

Director, Advanced Manned Missions, MT

Office of Manned Space Flight

NASA Headquarters

Wa shington, D. C. 20546

NASA Scientific \& Technical

Information Facility

P.O. Box 33

College Park, Maryland 20740

Director, Technology Utilization Division

Office of Technology Utilization

NASA Headquarters

Wa shington, D. C. 20546

National Aeronautics \& Space

Administration

Ames Research Center

Moffett Field, California 94035

Hans M. Mark

Attn: Library

National Aeronautics \& Space

Administration

Flight Research Center

P. O. Box 273

Edwards, California 93523

Attn: Library

National Aeronautics \& Space

Administration

Merland L. Moseson,

Goddard Space Flight Center

Code 620

Greenbelt, Maryland 20771

Attn: Library 
National Aeronautics \& Space

Administration

John F. Kennedy Space Center

Cocoa Beach, Florida 32931

Attn: Library

National Aeronautics \& Space

E. Cortwright

Administration

Langley Research Center

Director

Langley Station

Hampton, Virginia 23365

Attn: Library

National Aeronautics \& Space

Administration

Manned Spacecraft Center

Houston, Texas 77001

Attn: Library

National Aeronautics \& Space

Hans G. Paul

Administration

J. G. Thiobodaux, Jr.

George C. Marshall Space Flight Center

James Thomas

Huntsville, Alabama 35812

Attn: Library

Jet Propulsion Laboratory

4800 Oak Grove Drive

Pasadena, California 91103

Attn: Library

Defense Documentation Center

Cameron Station

Building 5

5010 Duke Street

Alexandria, Virginia 22314

Attn: TISIA

J. Blumrich

Henry Burlage, Jr.

Office of the Director of Defense

Research \& Engineering

Wa shington, D.C. 20301

Attn: Office of Asst. Dir.

(Chem. Technology)

RTD (RTNP)

Bolling Air Force Base

Wa shington, D. C. 20332 
Arnold Engineering Development Center Dr. H. K. Doetsch

Air Force Systems Command

Tullahoma, Tennessee 37389

Attn: Library

Advanced Research Projects Agency

Washington, D. C. 20525

Attn: Library

Aeronautical Systems Division

Air Force Systems Command

Wright-Patterson Air Force Base,

Dayton, Ohio

Attn: Library

Air Force Missile Test Center

L. J. Ullian

Patrick Air Force Base, Florida

Attn: Library

Air Force Systems Command

Capt. S.W. Bowen

Andrews Air Force Base

SCLT

Washington, D.C. 20332

Attn: Library

Air Force Rocket Propulsion

Laboratory (RPR)

Edwards, California 93523

Attn: Library

Air Force FTC (FTAT-2)

Donald Ross

1

Edwards Air Force Base, California 93523

Attn: Library

Air Force Office of Scientific Research

SREP

1

Wa shington, D. C. 20333

Dr. J.F. Masi

Attn: Library

Space \& Missile Systems Organization

Air Force Unit Post Office

Los Angeles, California 90045

Attn: Technical Data Center

Office of Research Analyses (OAR)

Holloman Air Force Base, New Mexico

Attn: Library

88330

RRRD

U. S. Air Force

Washington, D. C.

Col. C. K. Stambaugh

Attn: Library

Code AFRST 
Commanding Officer

U.S. Army Research Office (Durham)

Box CM, Duke Station

Durham, North Carolina 27706

Attn: Library

U.S. Army Missile Command

Dr. W. Wharton

Redstone Scientific Information Center

Redstone Arsenal, Alabama 35808

Attn: Document Section

Bureau of Naval Weapons

Department of the Navy

Wa shington, D. C.

Attn: Library

Commander

U.S. Naval Missile Center

Point Mugu, California 93041

Attn: Technical Library

Commander

J. Kay

Code RTMS- 41

U.S. Naval Weapons Center

China Lake, California 93557

Attn: Library

Commanding Officer

Naval Research Branch Office

1030 E. Green Street

Pasadena, California 91101

Attn: Library

Director (Code 6180)

U.S. Naval Research Laboratory

Wa shington, D. C. 20390

Attn: Library

Picatinny Arsenal

Dover, New Jersey 07801

Attn: Library

Air Force Aero Propulsion Laboratory

Research \& Technology Division

Air Force Systems Command

H. W. Carhart

1

United States Air Force

Wright-Patterson AFB, Ohio 45433

Attn: ARPR (Library)

R. Quigley

C. M. Donaldson 
Recipient

Electronics Division

Aerojet-General Corporation

P. O. Box 296

Azusa, California 91703

Attn: Library

Space Division

Aerojet-General Corporation

9200 East Flair Drive

El Monte, California 91734

Attn: Library

Aerojet Ordnance and Manufacturing

Aerojet-General Corporation

11711 South Woodruff Avenue

Fullerton, California 90241

Attn: Library

Aerojet Liquid Rocket Company

P. O. Box 13222

Sacramento, California 95813

Attn: Technical Library 2484-2015A

Aeronutronic Division of Philco Ford

Corp.

Ford Road

Newport Beach, California 92663

Attn: Technical Information

Department

Aerospace Corporation

2400 E. El Segundo Blvd.

Los Angeles, California 90045

Attn: Library-Documents

Arthur D. Little, Inc.

A. C. Tobey

1

20 Acorn Park

Cambridge, Massachusetts 02140

Attn: Library

ARO, Incorporated

J. G. Wilder

1

Arnold Engineering Development Center

Arnold AF Station, Tennessee 37389

Attn: Library

Battelle Memorial Institute

505 King Avenue

Columbus, Ohio 43201

Attn: Report Library, Room 6A
No.

Copies

1

1

Dr. L. H. Linder 


\section{Recipient}

Beech Aircraft Corporation

Boulder Facility

Box 631

Boulder, Colorado

Attn: Library

Bell Aerosystems, Inc.

Box 1

Buffalo, New York 14240

Attn: Library

Bendix Systems Division

Bendix Corporation

3300 Plymouth Street

Ann Arbor, Michigan

Attn: Library

Bell comm

955 L'Enfant Plaza, S. W.

Washington, D. C.

Attn: Library

Boeing Company

Space Division

P. O. Box 868

Seattle, Washington 98124

Attn: Library

Boeing Company

W. M. Smith

1

John M. Brueger

1

H. S. London

1

1625 K Street, N. W.

Wa shington, D.C. 20006

Chemical Propulsion Information Agency

Tom Reedy

1

Applied Physics Laboratory

8621 Georgia Avenue

Silver Spring, Maryland 20910

Chrysler Corporation

John Gates

1

Missile Division

P. O. Box 2628

Detroit, Michigan

Attn: Library

Chrysler Corporation

Space Division

P.O. Box 29200

New Orleans, Louisiana 70129

Attn: Librarian 


\section{Recipient}

Curtiss-Wright Corporation Wright Aeronautical Division

Woodridge, New Jersey

Attn: Library

University of Denver

Denver Research Institute

P. O. Box 10127

Denver, Colorado 80210

Attn: Security Office

Fairchild Stratos Corporation

Aircraft Missiles Division

Hagerstown, Maryland

Attn: Library

Reseach Center

Fairchild Hiller Corporation

Germantown, Maryland

Attn: Library

Republic Aviation

Fairchild Hiller Corporation

Farmington, Long Island

New York

General Dynamics/Convair

P. O. Box 1128

San Diego, California 92112

Attn: Library

Missiles and Space Systems Center

General Electric Company

Valley Forge Space Technology Center

P. O. Box 8555

Philadelphia, Pa. 19101

Attn: Library

Grumman Aircraft Engineering

Corporation

Bethpage, Long Island, New York

Attn: Library

Hercules Powder Company

Allegheny Ballistics Laboratory

P. O. Box 210

Cumberland, Maryland 21501

Attn: Library
No.

Copies

G. Kelley

Ralph Hall

Frank Dore

Joseph Gavin

1 
Honeywell, Inc.

Aerospace Division

2600 Ridgeway Road

Minneapolis, Minnesota

Attn: Library

IIT Research Institute

C. K. Hersh

1

Technology Center

Chicago, Illinois 60616

Attn: Library

Kidde Aerospace Division

Walter Kidde \& Company, Inc.

R. J. Hanville

567 Main Street

Belleville, New Jersey 07109

Ling-Temco-Vought Corporation

P. O. Box 5907

Dallas, Texas 75222

Attn: Library

Lockheed Missiles and Space Company

P.O. Box 504

Sunnyvale, California 94087

Attn: Library

Lockheed Propulsion Company

P.O. Box 111

Redlands, California 92374

Attn: Library

Marquardt Corporation

16555 Saticoy Street

Box 2013 - South Annex

Van Nuys, California 91409

Martin-Marietta Corporation

H. L. Thackwell

(Baltimore Division)

Baltimore, Maryland 21203

Attn: Library

Denver Division

Martin-Marietta Corporation

L. R. Bell Jr.

P. O. Box 179

Denver, Colorado 80201

Attn: Library

Dr. Morganthaler 


\section{Recipient}

Orlando Division

Martin-Marietta Corporation

Box 5827

Orlando, Florida

Attn: Library

Western Division

McDonnell Douglas Astronautics

5301 Bolsa Ave.

Huntington Beach, California 92647

Attn: Library

Mc Donnell Douglas Aircraft Corporation P. O. Box 516

Lambert Field, Missouri 63166

Attn: Library

Rocketdyne Division

North American Rockwell, Inc.

6633 Canoga Avenue

Canoga Park, California 91304

Attn: Library, Department 596-306

Space \& Information Systems Division

North American Rockwell

12214 Lakewood Blvd.

Downey, California

Attn: Library

Northrop Space Laboratories

3401 West Broadway

Hawthorne, California

Attn: Library

Purdue University

Lafayette, Indiana 47907

Attn: Library (Technical)

Rocket Research Corporation

Willow Road at 116 th Street

Redmond, Washington 98052

Attn: Library

Stanford Research Institute 333 Ravenswood Avenue

Menlo Park, California 94025

Attn: Library
No.

Designee

Copies

J. Fern

R. W. Hallet

1

G. W. Burge

P. Klevatt

R. A. Herzmark

1

R. R. J. Thompson

1

S. F. Jacobellis

Dr. William Howard

1

Dr. Bruce Reese

1

F. McCullough, Jr.

1

Dr. Gerald Marksman

1 


\section{Recipient}

Thiokol Chemical Corporation

Redstone Division

Huntsville, Alabama

Attn: Library

TRW Systems, Inc.

l Space Park

Redondo Beach, California 90278

Attn: Tech. Lib. Doc. Acquisitions

TRW

TAPCO Division

23555 Euclid Avenue

Cleveland, Ohio 44117

United Aircraft Corporation

D. H. Lee

1

Corporation Library

400 Main Street

East Hartford, Connecticut 06108

Attn: Library

United Aircraft Corporation

Pratt \& Whitney Division

Florida Research \& Development

Center

P. O. Box 2691

West Palm Beach, Florida 33402

Attn: Library

United Aircraft Corporation

United Technology Center

P. O. Box 358

Sunnyvale, California 94038

Attn: Library

Vickers Incorporated

P. T. Angell

1

1

R. J. Coar

1

Dr. Schmitke

Dr. David Altman

1

1

Box 302

Troy, Michigan

Vought Astronautics

Box 5907

Dallas, Texas

Attn: Library 